EOEXPLORERS INTERNATIONAL, INC.

DR. JAN KRASON
PRESIDENT

\title{
GEOLOGY, ENERGY AND MINERAL RESOURCES ASSESSMENT OF THE WYMOLA AREA, ARIZONA
}

\author{
BY \\ SUSAN K. CRUVER, A. WODZICKI AND JAN KRASON \\ GEOEXPLORERS INTERNATIONAL, INC. \\ 5701 East Evans Avenue \\ Denver, Colorado 80222 \\ Telephone 303-759-2746
}

\author{
Prepared for: \\ United States Department of the Interior \\ BUREAU OF LAND MANAGEMENT \\ December 31,1982
}

Geo-Scientific, Unofessional and Gnginerring Sersices 
-

-

- 
Figure 1: Physiographic map of south-central Arizona showing location of Sonora, Wymola and Kitt Peak areas. Depth to bedrock contours, interval $=1600 \mathrm{ft}$. , from Oppenheimer and Sumner, 1980.

Figure 2: Paleotectonic and paleogeographic maps of Arizona showing location of the Wymola GRA.

Figure 3: Geologic, energy and mineral resources map of the Wymola area, Arizona.

Figure 4: Legend for geologic, energy and mineral resources maps.

Figure 5: Composite stratigraphic column of southern Arizona from Eberly and Stanley (1978).

Figure 6: Claim density map, with oil and gas leasing status, of the Wymola area, Arizona.

Figure 7: Location of oil and gas exploration wells in southern Arizona, after Jones (1979).

Figure 8: Favorability and level of confidence map for metallic mineral resources of the Wymola area, Arizona.

Figure 9: Favorability and level of confidence map for uranium resources of the Wymola area, Arizona.

Figure 10: Favorability and level of confidence map for non-metallic resources of the Wymola area, Arizona.

\section{TABLES}

Table 1: Wilderness Study Areas in the Wymola GSA.

Table 2: Claim density records in the Wilderness Study Areas (WSA), Wymola GRA according to BLM (June 1982), Arizona State Office.

Table 3: Geological environments of the Wymola area and associated potential mineral deposit types. 


\section{GEOLOGY, ENERGY AND MINERAL RESOURCES ASSESSMENT \\ OF THE WYMOLA AREA, ARIZONA}

by

Susan K. Cruver, Antoni Wodzicki and Jan Krason

\section{SUMMARY}

The Wymola "Geological, Energy and Minerals (GEM) Resources Area" (GRA) lies within Pinal and Pima Counties, Arizona, and contains the following Wilderness Study Areas (WSAs):

Picacho Mountains (020-194), and Ragged Top (020-197).

Basement rocks consist of Precambrian ( 1.7 to 1.68 b.y.B.P.) metasedimentary schists intruded locally by granites 1.7 to 1.6 and 1.5 to 1.4 b.y.B.P. The basement is unconformably overlain by younger Precambrian sediments and basalts and intruded by diabases l.l b.y.B.P. Precambrian rocks are unconformably overlain by Paleozoic shallow marine clastics and carbonates. During the mid-Mesozoic a magmatic arc extended across southern Arizona and a thick sequence of Jurassic (?) to Cretaceous continental red beds were deposited in the GRA. Andesites were erupted and quartz monzonite and associated porphyries were intruded during the Laramide (70-50 m.y.B.P.) and porphry copper mineralization of the Silver Bell Mine in the southern part of the GRA formed at this time. The mid-Tertiary orogeny lasted from 35 to 14 m.y.B.P. and involved the following: Deposition of a thick sequence of fluvial and lacustrine sediments in northwest-striking downwarps, outpouring of voluminous calc-alkaline volcanics dominated by ash-flow deposits possibly related to cauldrons, emplacement of metamorphic core complexes, and listric normal faulting which offset mid-Tertiary volcanic and sedimentary rocks. Basin and range faulting became dominant 14-4 m.y.B.P. and was accompanied by bimodal volcanism. Since $4 \mathrm{~m} \cdot \mathrm{y} \cdot \mathrm{B} . \mathrm{P}$. the main geological processes have been erosion and deposition of alluvium.

Geologic environments potentially favorable for the occurrence of mineral or energy resources in the GRA include: Older Precambrian metasedimentary schist, older Precambrian granites, younger Precambrian sediments and diabases, Paleozoic and Mesozoic sediments, Laramide intrusives, mid-Tertiary metamorphic core complexes, mid-Tertiary volcanics and basin-fill sediments, Late Tertiary basin-fill sediments, recent alluvium and active geothermal areas.

Hydrothermal copper, with lesser lead and zinc, deposits are associated with Precambrian schists, granites and diabases. To the north of the area, uranium deposits are found in younger Precambrian sediments associated with diabase intrusions but no occurrences are known in the GRA. Oil and gas may 
have formed in Paleozoic sediments, but none has yet been discovered. Laramide intrusives and Paleozoic roof pendants in the southern part of the GRA are host rocks for the important porphyry copper deposits of the Silver Bell Mine and hydrothermal mineralization present in older rocks may also be related to Laramide intrusives. Many copper-bearing quartz veins occur in the Picacho Mountains metamorphic core complex. Silver, lead, copper, gold and manganese mineralize mid-Tertiary volcanics. Mid- to late Tertiary basin-fill sediments contain abundant uranium source rocks and permeable horizons and locally may contain reductants. Evaporites and zeolites occur in late Tertiary basin-fill sediments. Placer gold deposits may occur in recent alluvium. Temperatures reaching $100^{\circ} \mathrm{C}$ have been measured in wells in deep basins in the GRA.

The Picacho Peak WSA is underlain by a mid-Tertiary metamorphic core complex and copper mineralization is associated with the rocks. The WSA is moderately favorable for the accumulation of metallic minerals and has low favorability for uranium.

The Ragged Top WSA is underlain by Precambrian granites, sediments and diabases, Cretaceous andesites, mid-Tertiary volcanics, intrusives and sediments and Quaternary alluvium. One copper prospect in the WSA has produced and copper, gold, barite, and lead occurrences, some past producers, are located within close proximity to the WSA. The rich porphry copper deposits of the Silver Bell Mine are located less than three miles south of the WSA. The WSA has low to moderate favorability for metallic mineralization, and low favorability for uranium and non-metallic resources.

1. Field checking mineral occurrences and prospects in the WSAs to determine if mineralization may be extensive.

2. Field checks for hydrothermal alteration; presence of chloritic breccias, dislocation surfaces and upper plate rocks in the Picacho Mountains metamorphic core complex; and occurrence of pegmatites in Precambrian granites.

3. Geochemical sampling and analysis of chloritic breccias, schists and rocks of dislocation surfaces to determine uranium and metallic mineral potential. 


\section{INTRODUCTION}

\section{Purpose and Methodology}

The need and desirability of the "Geological, Energy and Minerals (GEM) Resources Assessment" of the "Wilderness Study Areas" (WSA) has been recognized and a series of such studies was recently undertaken by the Bureau of Land Management (BLM). The execution of the objective work is being performed by various contractors.

The selected Wilderness Study Areas, widely scattered within the "Sonoran Desert and Mexican Highlands" and grouped into "Region 5", have been studies and assessed by Geoexplorers International, Inc. The present report pertains to two WSAs in south-central Arizona which have been grouped together into the Wymola Geological, Energy and Mineral Resources Area (GRA).

The purpose of the present study is to assess the potential for locateable, leaseable and saleable resources within the GRA, and speciffcally within each of the WSAs. This assessment has been carried out through literature study of the geology, structure and economic geology of the GRA, and a consideration of the regional paleogeographic, plate tectonic and metallogenic setting of the GRA within the southern Cordillera. Thus, the assessment is based not only on data from the GRA itself, but also on metallogenic concepts within the regional paleogeographic and plate tectonic framework.

Geological, Energy and Mineral (GEM) Resources Area (GRA)

In this report, "resources" are defined as mineral and/or fossil fuel concentrations amenable to economic development under current or reasonably 
anticipated conditions. Resources include reserves and other mineral or fossil fuel concentrations that may eventually become reserves but are currently either economically or technically not recoverable. Resources are also defined as deposits inferred to exist, but not yet discovered.

Considering the BLM's requirements, the GRA boundaries have been determined in accordance with the following criteria:

1. The size of the GRA is approximately 211,064 acres $(853.8$ $\mathrm{km}^{2}$ ), which if shown on the map to the scale of $1: 250,000$ (also required by BLM) does not exceed a sheet of paper 8.5 by 11 inches,

2. GRA boundary does not cut across a Wilderness Study Area, and

3. The geologic environment and mineral occurrences are also taken into primary consideration.

The criteria for establishment of the Wilderness Study Areas are not the subject of this report. Also, their boundaries, code numbers and names have been established by the Bureau of Land Management prior to this study. The name "Wymola GRA," as described below, has been sugested and used by the authors of this report as no name has yet been established by the Bureau of Land Management.

\section{Location and Access}

The Wymola Geological Resources Area is located in Pinal and Pima Counties in south-central Arizona. It lies within the Phoenix Resource Area of the BLM-administered Phoenix District. It occupies the western part of the Tucson 1:250,000 quadrangle, approximately between latitude $32020^{\circ} \mathrm{N}$ and $32^{\circ} 50^{\circ} \mathrm{N}$ and longitude $111^{\circ} 10^{\circ} \mathrm{W}$ and $111^{\circ} 40^{\circ} \mathrm{W}$. The two wSAs within the Wymola GRA are listed in Table 1 and their locations are shown in Figure 1. 
Table 1. WILDERNESS STUDY AREAS IN THE WYMOLA GRA

\begin{tabular}{cc|c|l}
\hline WSA NO. & WSA Name & Acres & $\mathrm{km}^{2}$ \\
\hline $020-194$ & Picacho Mountains & 6,400 & 25.7 \\
$020-197$ & Ragged Top & 4,460 & 17.9 \\
\hline & Total & 10,860 & 43.6
\end{tabular}


Important access into the GRA is provided by the following: the Southern Pacific Railroad and Interstate Highway 10, which run northwestsoutheast across the GRA, and Arizona Highway 87, which runs from the northern edge of the GRA south to I-10. Access to the valleys in the GRA is along numerous light-duty and unimproved roads, but access for vehicular traffic to the mountainous areas, with the exception of Silver Bell Mountains, is very limited. Eloy, in the northwestern part of the GRA, is the largest town in the area; several smaller towns are scattered throughout the lowlands of the GRA.

\section{PHYSIOGRAPHY}

The Wymola GRA lies within the Sonoran Desert section of the Basin and Range Province (Fenneman, 1931). The area has two topographic grains: a north-south to northeast-trending topographic grain which reflects Miocene Basin and Range faulting and, in the Picacho Mountains, lineation of a midTertiary metamorphic core complex; and a northwest-trending topographic grain in the Silver Bell and West Silver Bell Mountains of the southwest part of the GRA which reflects the trend of pre-Laramide structures. Basin and Range fault scarps have been eroded back to form extensive pediments and the range fronts are embayed (Tucker, 1980). This is because much of southern Arizona has been almost free of tectonic activity for the past several million years.

The GRA can be divided into two distinct physiographic terrains (fig. 1): mountainous-to-hilly and lowland terrains.

The mountainous-to-hilly terrain is comprised of the Silver Bell Mountains, Ragged Top and surrounding area, Cerro Prieto, Picacho Peak, Picacho Mountains and several hills and buttes scattered throughout the area.

Lowlands include the Santa Cruz Flats, Avra Valley and McClellan Wash and the broad, gently sloping alluvial plain coming off the Tortolita 
Mountains, Suizo Mountains and Durham Hills (located east of the GRA). All are probably fault-bound basins which have been widened through the formation of pediments. In the western part of the area, the Picacho Basin which underlies the Santa Cruz Valley is filled with more than 9600 feet of sediments as is the Avra Valley in the southeastern part of the GRA (fig. 1; Oppenheimer and Sumner, 1980). The basin between the Picacho Mountains and the ranges east of the GRA is shallower, filled with between 6400 and 8000 feet of sediments.

\section{GEOLOGY}

Southern Arizona is an area of highly complex geology. Rocks range in age from Precambrian to Recent, and the region has been affected by Precambrian, mid-Mesozoic, Laramide and Mid-Tertiary orogenies and by Basin and range faulting. Important advances in the understanding of this complex terrain have been made since the publication of the Geologic Map of Arizona (Wilson et al., 1969) and have been summarized by Reynolds (1980). These advances have largely been the result of a greatly increased number of radiometric data (Shafiqullah et al., 1980); regional analysis of deformation (Rehrig and Heidrick, 1967; Davis, 1981); recognition of metamorphic core complexes (Davis and Coney, 1979; Coney, 1980; Davis et al., 1980; Rehrig and Reynolds, 1980); recognition of the relationship between subduction magmatism and metallogenesis in the southern Cordillera (Coney and Reynolds, 1977; Davis et a1., 1981); and an increased level of mapping of Cenozoic basins as a result of intense uranium exploration during the late 1970s (Eberly and Stanley, 1978; Scarborough and Wilt, 1979).

The lithology and stratigraphy, structural geology and tectonics, paleontology and geologic history of the Wymola GRA are discussed in this section in order to facilitate the assessment of mineral potential within the GRA and, 
specifically, within the enclosed WSAs. The regional geologic setting and detailed geology of the Wymola GRA are shown in Figures 2 and 3 respectively.

\section{Lithostratigraphy - Rock Units}

In southern Arizona, older Precambrian crystalline basement is overlain by younger Precambrian and Paleozoic shallow marine sediments; Mesozoic and Laramide intrusives, volcanics and continental clastic sediments; midTertiary volcanics and clastic continental sediments; and late Tertiary volcanics and valley-fill sediments. Intensive activity and metamorphism took place during the Precambrian, mid-Mesozoic, Laramide and mid-Tertiary. Metamorphic core complexes were probably emplaced during the latter event.

Older Precambrian Rocks

Older Precambrian rocks in Arizona crop out most extensively in the northwest-trending Central Mountain region, to the north of the Wymola GRA. Here they have been divided into three distinct northeast-trending belts (Titley, 1982; see Figure 2C) which, according to Anderson (1976), accreted onto the North American craton from the southeast.

The most northwesterly of these belts consists of gneisses which are in part metavolcanic facies (Stensrud and More, 1980) and were deposited about 1.8 b.y.B.P. (Titley, 1982). The central belt consists of the Yavapai Series which was deposited $1.82-1.775$ b.y.B.P. (Anderson and Silver, 1976). It is a greenstone belt which is approximately 40,000 feet thick and is dominated by volcanic and volcanoclastic rocks of basaltic to rhyolitic composition (Anderson and Silver, 1976; Titley, 1982) and has been metamorphosed to the greenschist facies. Massive sulfide copper-zinc deposits are associated with submarine rhyolitic volcanism, especially in the Prescott-Jerome area (Donnelly and Hahn, 1981). The southeastern belt consists of the Pinal 
Figure 2: Paleotectonic and paleogeographic maps of Arizona showing location of the Wymola GRA.

A. Location of Precambrian terrains and the Holbrook, Bright Angle-Mesa Butte and Colorado lineaments, after Warner (1978) and Titley (1982).

B. Location of mid-Mesozoic magmatic arc, the Mojave-Sonora megashear and mid- to late Mesozoic red beds, after Dickinson (1981). The red beds postdate the magmatic arc and probably extend farther to the southwest than shown.

C. Location and age trends of major porphyry copper deposits. Note that these are aligned parallel to northwest-trending Paleozoic-Mesozoic discontinuities (Lowe11, 1974; numbers 1-6 correspond to discontinuities named in Heidrick and Titley, 1982), along northwest-trending Laramide magmatic arcs ( $v$ pattern), and along northeasterly Precambrian trends (Heidrick and Titley, 1982). Curved black lines show location of arc at different times, as given.

D. Location of Precambrian alkali and alkali-calcic intrusions and mid-Tertiary metamorphic core complexes, mid-Tertiary alkali-calcic volcanics and sedimentary domains (Scarborough and Wilt, 1979). 


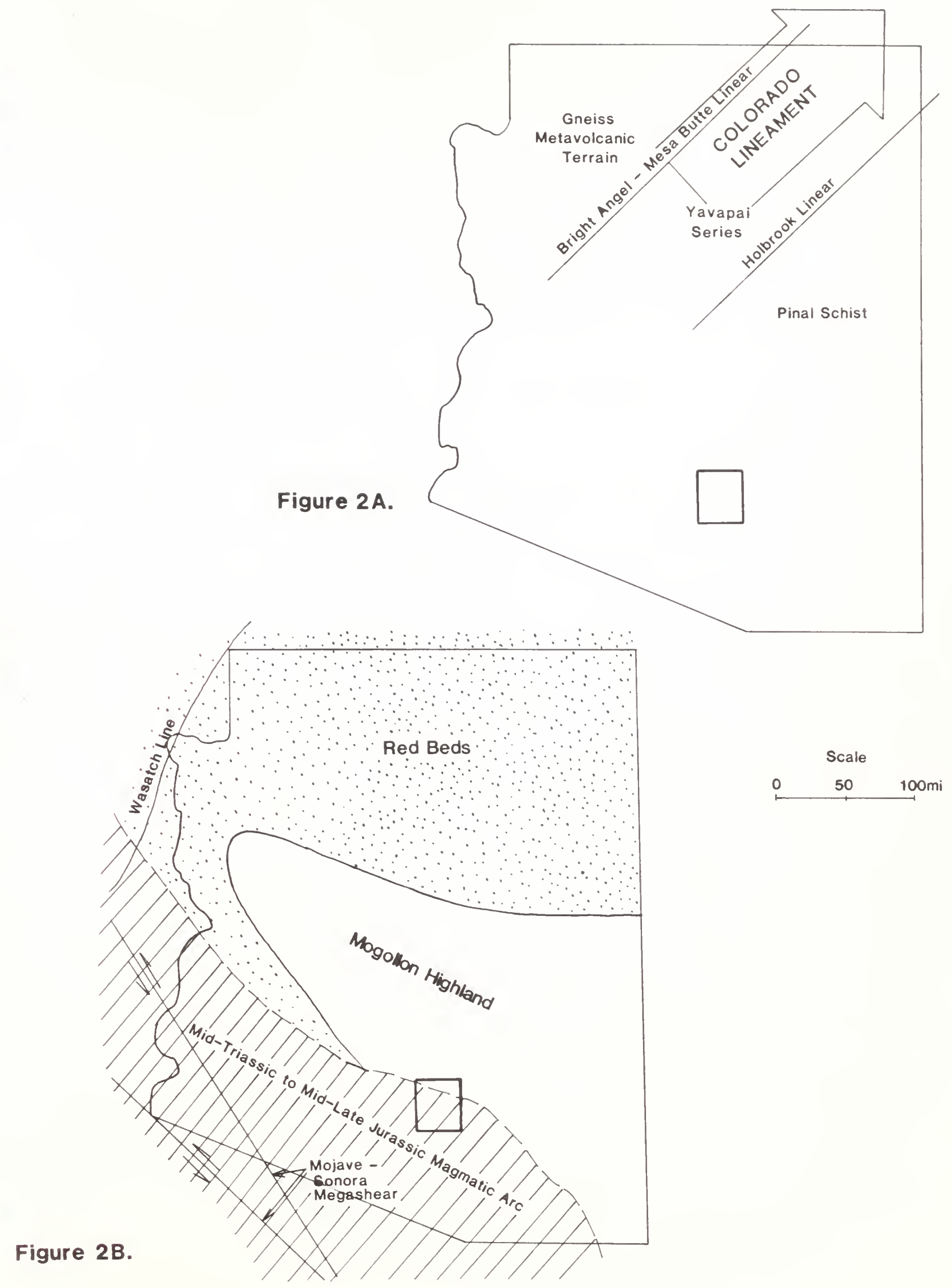




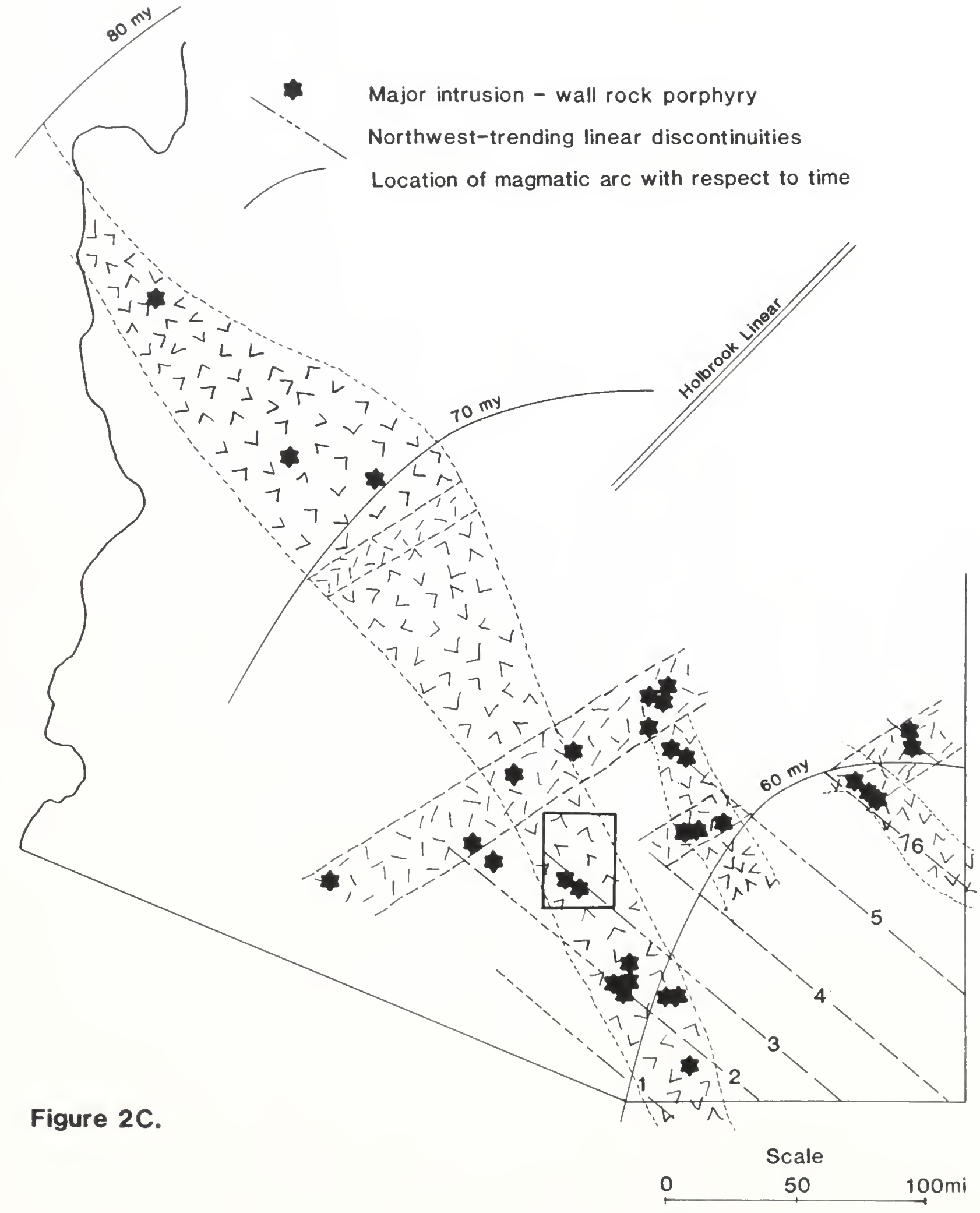




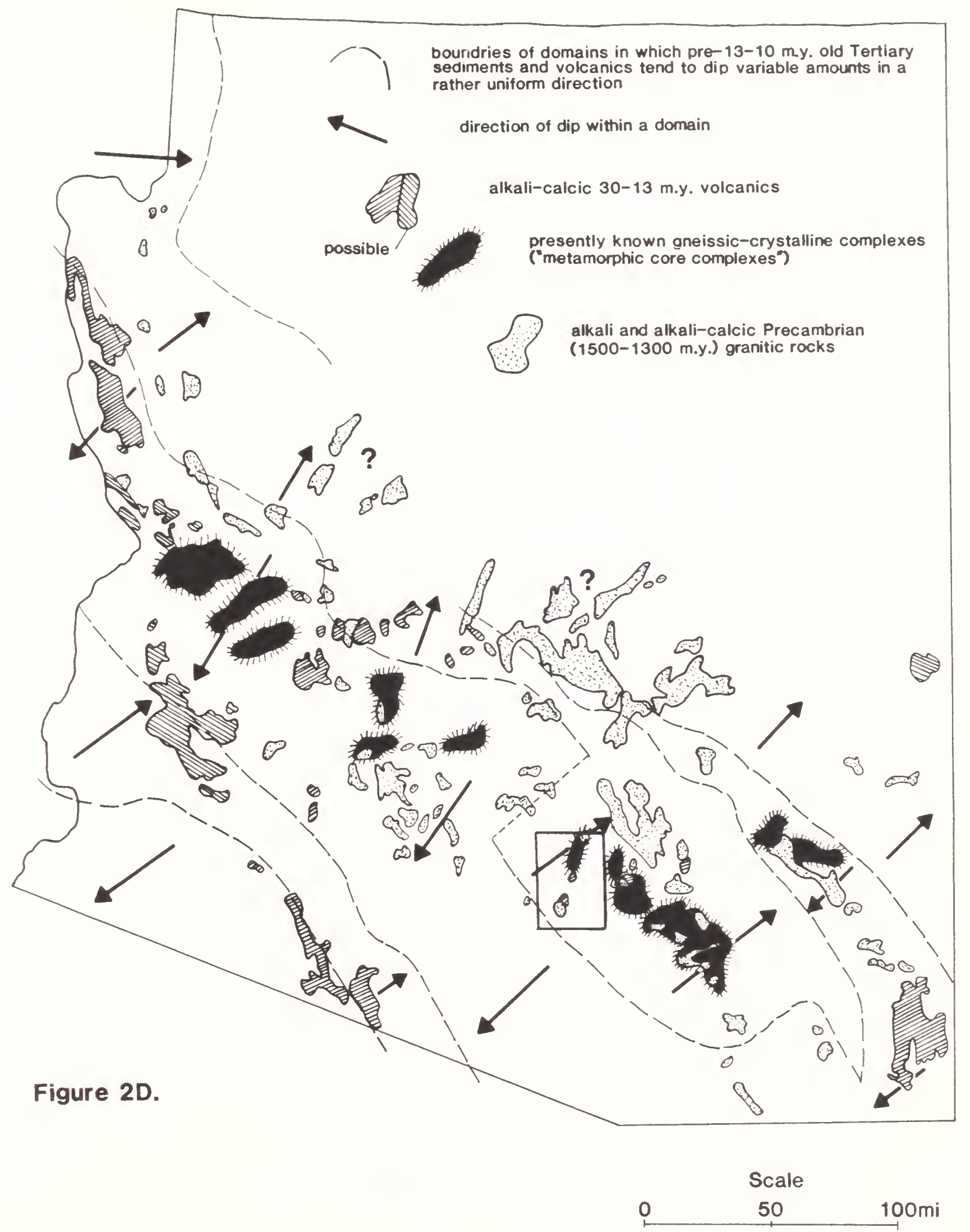




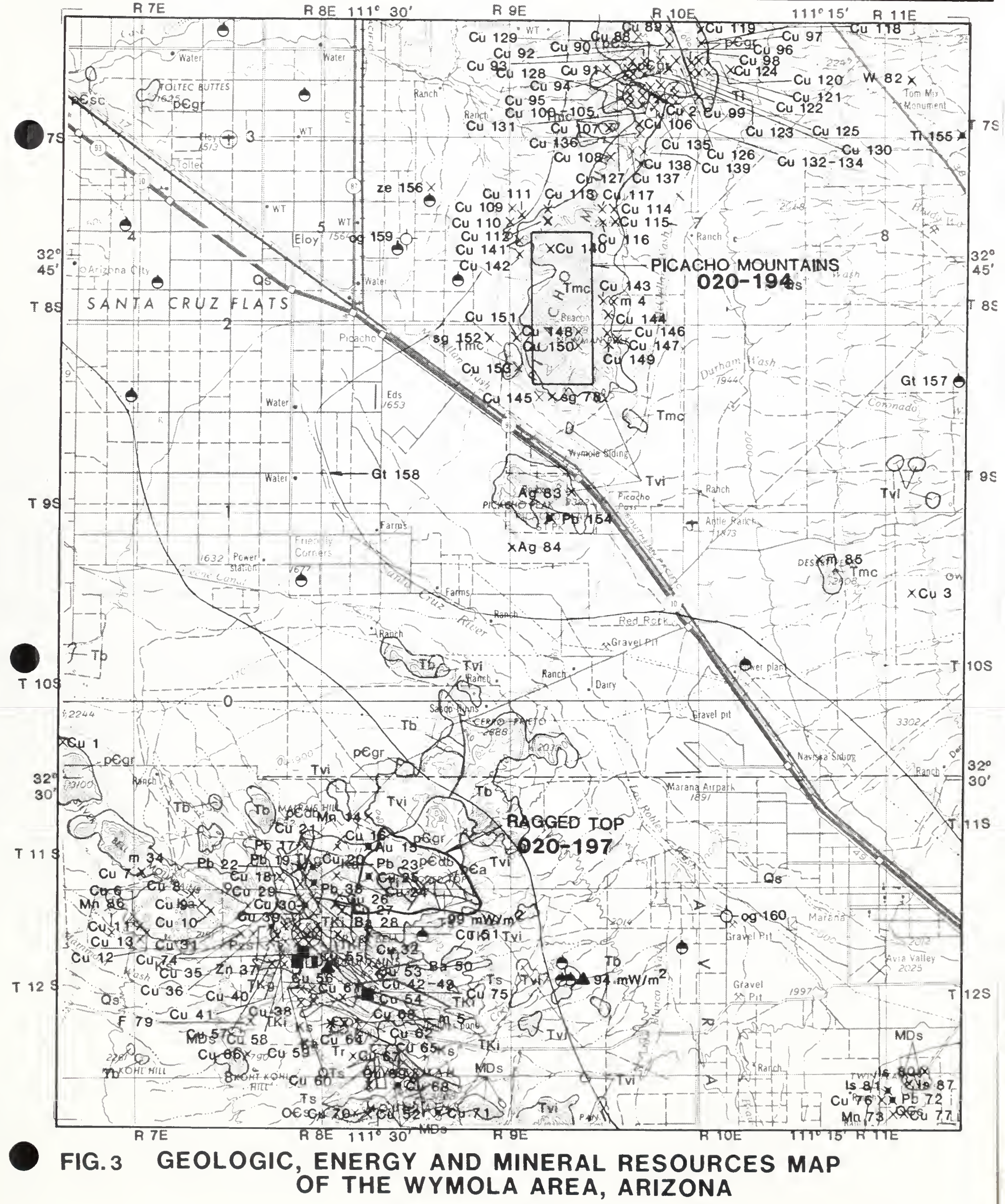

Scale

$1: 250,000$

LEGEND: see enclosed 
Figure 4.

GEOLOGIC, ENERGY AND MINERAL RESOURCES MAPS

Scale of all maps is 1:250,000 or as otherwise indicated. 


\section{LITHOSTRATIGRAPHY}

After Wilson et al. (1969) with modifications from Johnson (1981). Shafiqullah (1980), Eberly and Stanley (1978), Shafiqullah et al. (1976) and Yeend (1976).

\section{QUATERNARY}

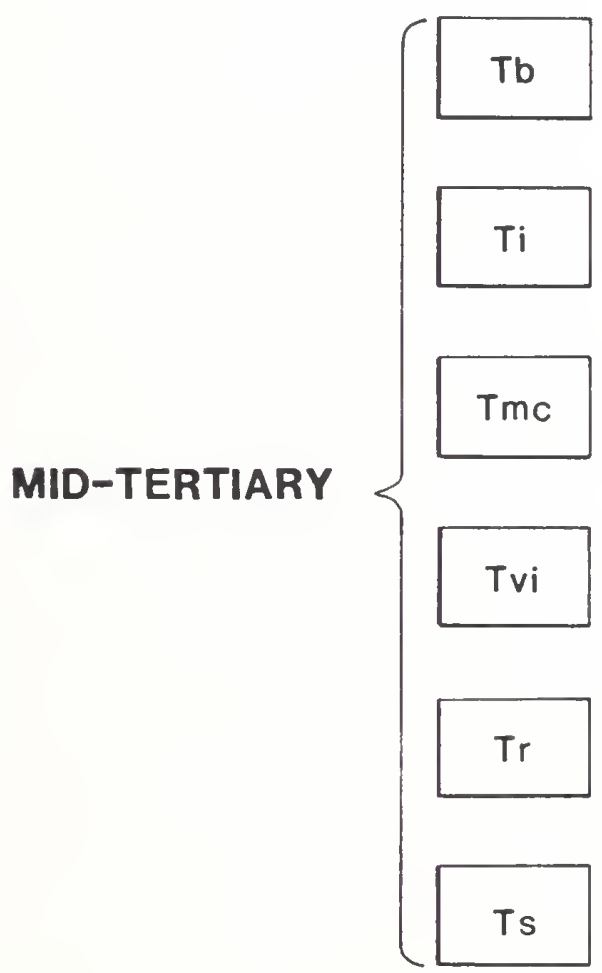

Qs

\section{QTs} LATE TERTIARY
TO QUATERNARY

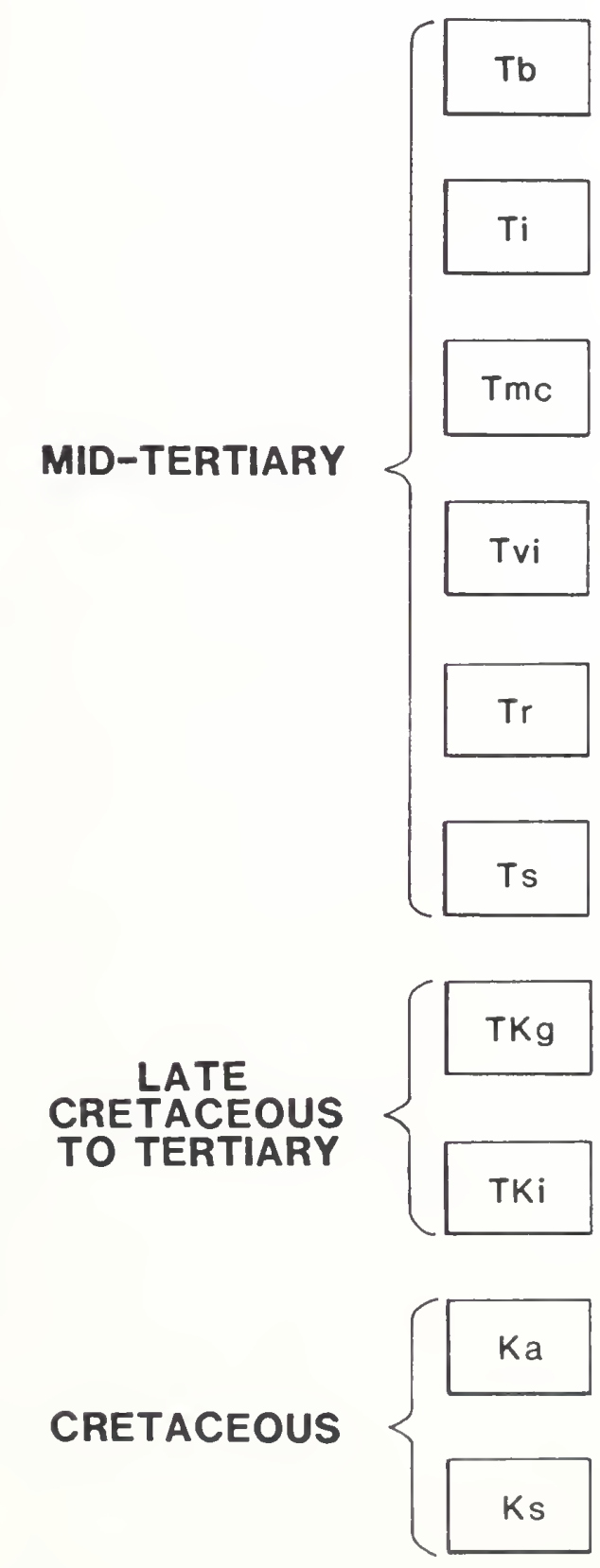

ALLUVIUM - Sand, gravel, silt, stream deposits, fans and pediment cappings.

BASALT - Flows and flow breccias of basalt and basaltic andesite composition.

DIKES, SILLS, PLUGS AND SMALL STOCKS - Includes North Star stock (granite and monzonite) and intrusive of unknown nature at Ragged Top.

METAMORPHIC CORE COMPLEXES - Muscovite-biotite gneiss, mylonitic gneiss, mostly metasedimentary schists, hornblende-biotite granodiorite, intermediate to felsic dikes.

INTERMEDIATE VOLCANICS - Andesite, trachyandesite, trachyte, ultrapotassic trachytes, latites, quartz latites. Flows, ash flow tuffs, tuff breccias.

RHYOLITE - Flows, pyroclastics and breccias, mostly rhyolitic in composition; also includes conglomerate and other Tertiary sediments.

SEDIMENTS - Fluvial arkosic sandstone, fanglomerate, lacustrine clay and limestone.

LARAMIDE QUARTZ MONZONITE - Stocks and dikes.

LARAMIDE INTRUSIVES AND ASSOCIATED ROCKS - Alaskite, dacite porphyry, andesite porphyry, syenodiorite dikes.

CRETACEOUS ANDESITE - Flows, breccias and lahars.

CRETACEOUS SEDIMENTS - Buff to maroon arkose, siltstone and pebble conglomerate. 


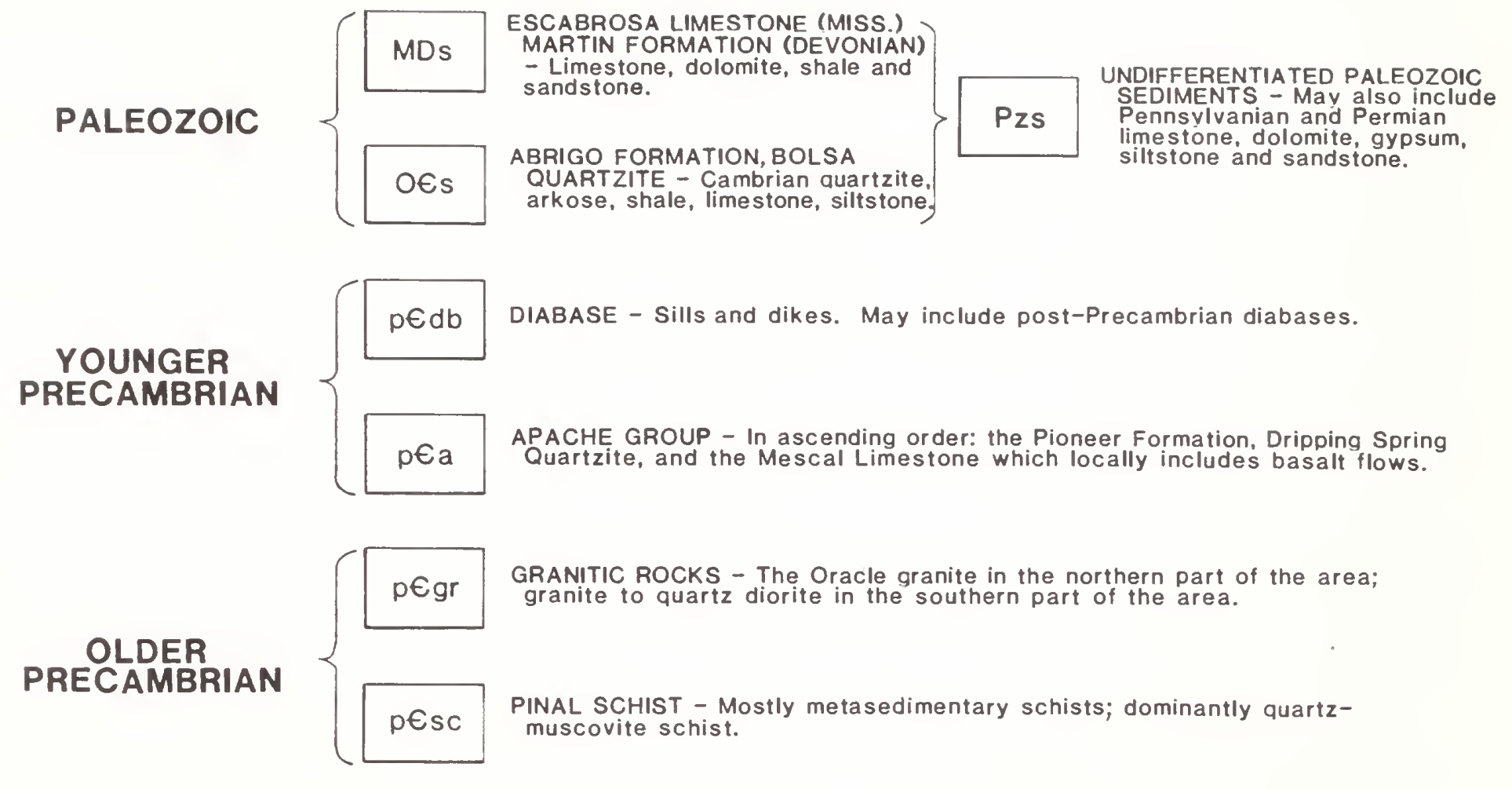




\section{SPECIAL SYMBOLS \\ OF STRUCTURAL FEATURES \\ After U.S. Geological Survey}

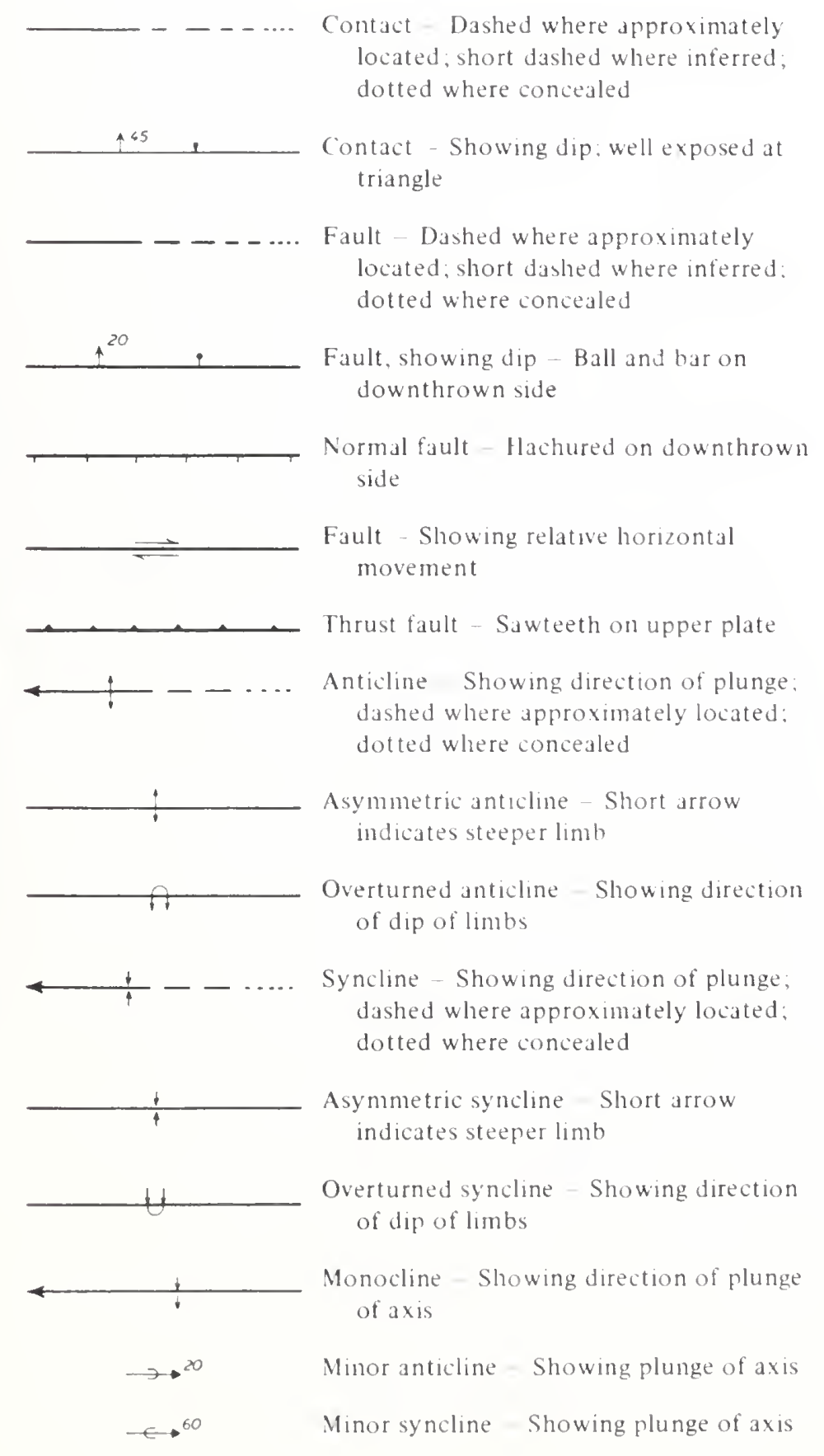

Strike and dip of beds - Ball indicates top of beds known from sedimentary structures

$\stackrel{70}{ \pm}$ Inclined $\oplus$ Horrzontal

+ Vertical 40 Oversurned

Strike and dip of foliation -20 Inclined ^ Vertcial * Ilorizontal

Strike and dip of cleavage 15 Inclined $\rightarrow$ Vertical if Iforizontal

Bearing and plunge of lineation

15 Inclined - Vertical $\rightarrow$ Ihorszontal

Strike and dip of joints

- Inclined - Vertical - Ilorizontal

Note: planar symbols (strike and dip of heds. foliation or schistosity. and cleavage) inay he combined with linear symbols (1) record data observed at same locality hy superimposed symhols at point of ohservation. Coexisting planar symbols are shown intersecting at point of ohservation. 


\section{SPECIAL SYMBOLS}

\section{FOR ENERGY AND MINERAL RESOURCES}

\section{KNOWN DEPOSITS AND OCCURRENCES}

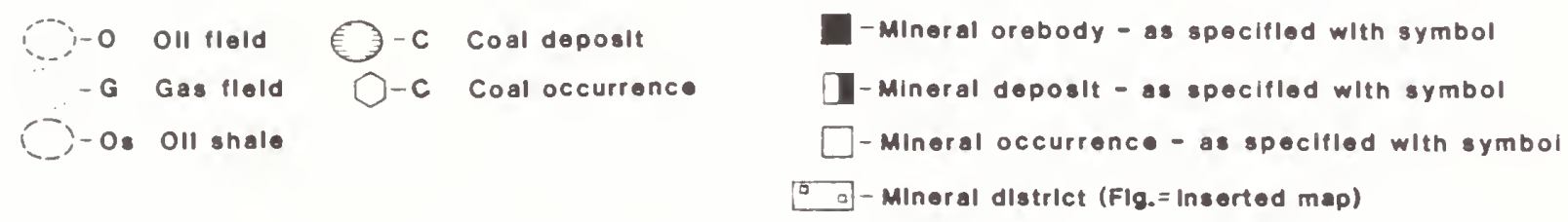

EXPLORATION AND/OR MINING ACTIVITY

\section{MINERALS AND COAL}

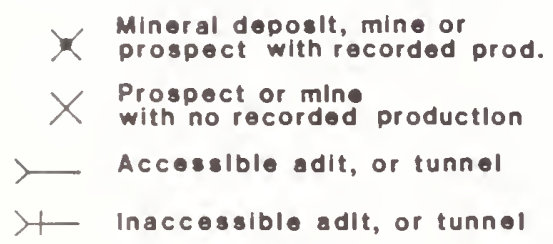

\section{GROUND WATER}

Water well of special importance

Water well of high yleld

Flowing water well

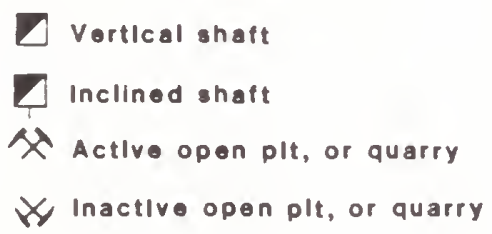

- Actlve gravel or clay (cl) plt - Inactlve gravel or clay (cl) plt $\bigoplus$ Exploration holo with data avallablo (8) Exploration hole without data $x$ MInIng distrlct (FIg.= Inserted map) 


\section{MINERAL RESOURCES}

\section{METALS}
Al Aluminum
Sb Antimony
As Arsenic
Be Beryilium
BI Bismuth
Cd Cadmium
Cr Chromium
Cs Cesium
Co Cobalt

Cu Copper
Ga Galilum

Ge Germanium

Au Goid

Fo Iron

Pb Load

LI Lithium

Mn Manganese

Hg Mercury

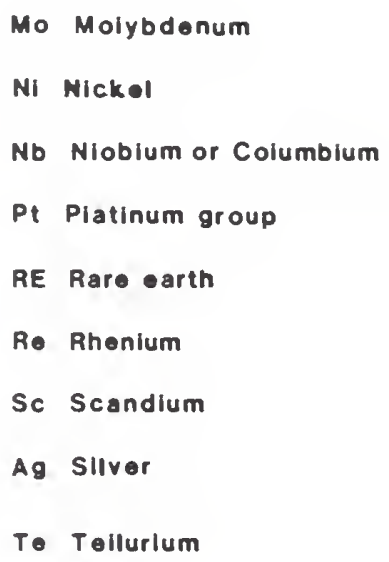

Ti Thailium

Sn Tin

TI Titanium

W Tungston

V Vanadlum

Zn Zinc

$\mathrm{Zr}$ Zirconium and Hf Hafnium

\section{NONMETALS - INDUSTRIAL MINERALS}

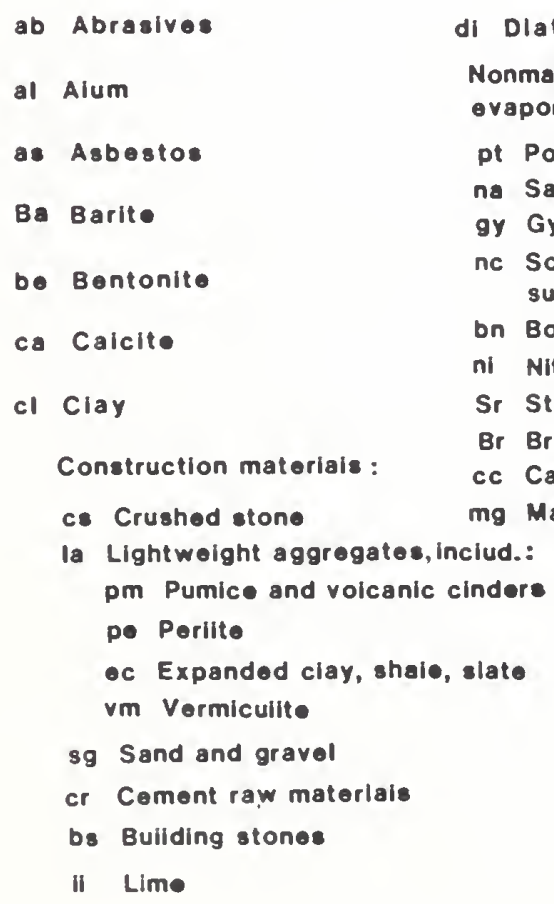

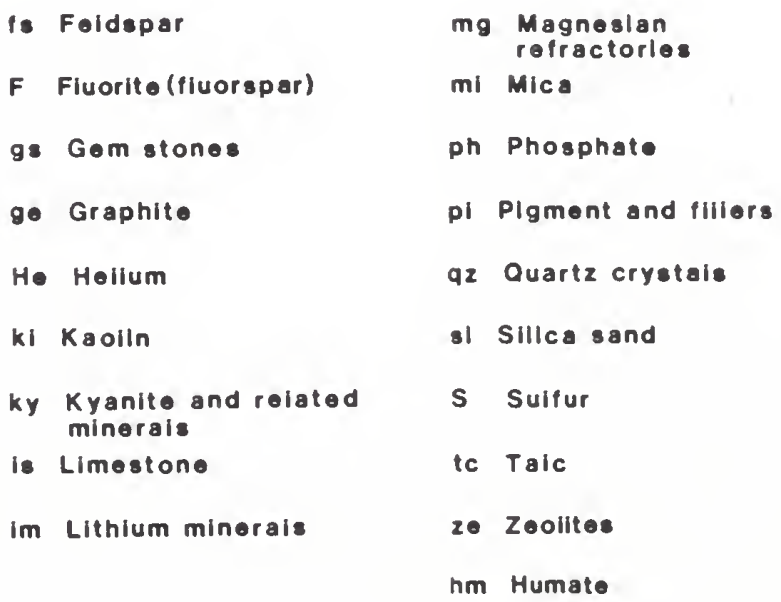




\section{SPECIAL GEOLOGICAL FEATURES}

POINT OF SPECIAL GEOLOGIC INTEREST
m Minerai occurrence
Fossil locality
v Volcanic phenomenon
t Stratigraphic sequence

- Structural, bedding, foliation, etc.,

b Brecclation, hear zone, etc.,

y High yield spring

p Spring with mineral water u Radioactive epring

g Thermal sping

a Extensive rock alteration

r Lithologic type locality

FAVORABILITY POTENTIAL AND LEVEL OF CONFIDENCE FOR MINERAL RESOURCES

FAVORABILITY:

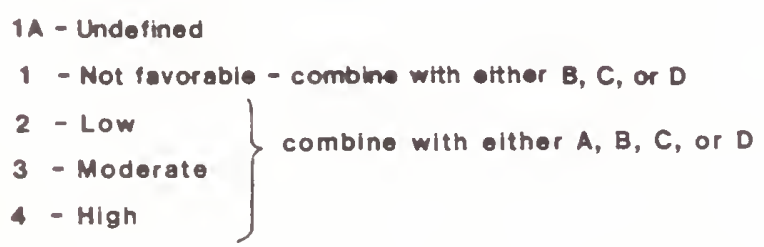

LEVEL OF CONFIDENCE:

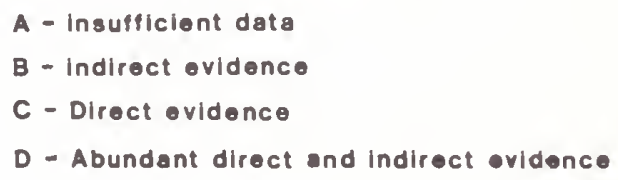


Schists which were deposited 1.7 - 1.68 b.y.B.P. (Silver, 1978) and consist of quartz-muscovite or quartz-muscovite-chlorite schist, arkose and quartzite (Titley, 1982).

The older Precambrian rocks were metamorphosed and intruded by granites during the Arizonan revolution 1.76 - 1.63 b.y.B.P. (Damon, 1968) and were intruded by granites during the Mazatzal revolution 1.5 - 1.4 b.y.B.P. (Damon, 1968; Silver et al., 1977).

According to Shafiqullah et al. (1980), the metamorphic rocks in the Sonoran Desert section of the Basin and Range Province are generally dark amphiholite gneisses and augen gneisses, in contrast to the lower grade greenschists to the northeast. The southwestern extension of the boundary between the Yavapai Series and the Pinal Schists and the approximately coincident Holbrook Line (see Figure 2A) of the magnetic anomalies projects to the west of the GRA.

The granitic rocks, according to Wilson et al. (1969), may range in composition between granite and quartz diorite.

Older Precambrian schists, gneiss and granite crop out in the Wymola GRA. Pinal Schist crops out in the northwest corner of the GRA and in the northern Picacho Mountains, where it is locally gneissic and is a roof pendant of the Oracle Granite (Johnson, 1981). The Oracle Granite in that area is 1.420 to $1.450 \mathrm{~b} \cdot \mathrm{y}$. old and is locally foliated (Johnson, 1981). Precambrian granitic rocks also crop out in the West Silver Bell Mountains and at Ragged Top in the southwest part of the GRA and at Toltec Buttes in the northwest.

Younger Precambrian

Younger Precambrian sediments of the Apache Group and a diabase sill dated as $1,100 \pm 15 \mathrm{~m} \cdot \mathrm{y} \cdot$ old (Titley, 1982) crop out in the Ragged Top WSA 
in the south central part of the GRA, and another diabase intrusion is located a few miles to the west of WSA.

The Apache Group consists, in ascending order, of the Pioneer Formation, the Dripping Spring Quartzite and its basal Barnes Conglomerate Member, and the Mescal Limestone which locally includes basalt flows. Contact between formations of the Apache Group are unconformable and total thickness of the Apache Group is between 1250 and 1600 feet in areas to the northeast where complete sections have been measured (Shride, 1967; Tit 1ey, 1982). The Pioneer Formation consists of basal quartzite and quartz pebble conglomerate overlain by arkose, grayish red tuffaceous siltstone and silty mudstone. Measured sections are from 150 to 500 feet thick. The Barnes Conglomerate, an arkosic quartz pebble conglomerate, is the basal member of the Dripping Spring Quartzite. Thick- to thin-bedded arkose and feldspathic quartzite, often cross-bedded, overlies the Barnes Conglomerate Member. Thinly laminated or cross-laminated, commonly pyritic siltstone with abundant mud cracks and stylolites comprises the upper member of the 550 to 7000 foot Dripping Spring Quartzite. Cherty limestone, locally metamorphosed to calc-silicate marble, overlain by algal dolomite and limestone, make up the Mescal Limestone, which is 190 to 400 feet thick. Porphyritic amygdaloidal basalt overlies the Mescal (Shride, 1967). In the Ragged Top WSA, both the basalt flow and the Mescal Limestone may have been removed by erosion (Titley, 1982; Shride, 1967 ). Intrusion of diabase sills and dikes followed local folding of the younger Precambrian sediments (Titley, 1982). Sills are up to 1200 feet thick. Precambrian diabases host ore mineralization in the porphry copper deposit at Ray, Arizona (Titley, 1982) and may have been the source of uranium for deposits in the Dripping Spring Quartzite (Granger and Raup, 1969 ). 
Paleozoic

Paleozoic sedimentary rocks occur in scattered outcroppings in the southernmost part of the GRA and may underlie Cretaceous volcanics in the Ragged Top WSA. Where present, total thickness of the Paleozoic section is 4000 to 5000 feet and includes the Bolsa Quartzite, Abrigo Formation, Martin Formation, Escabrosa Limestone and possibly the Scherrer Formation and other Paleozoic units in the Silver Bell Mountains. These units are shelf sediments deposited on a stable platform east of the Wasatch Line (fig. 2B), separating them from the Cordilleran geosyncline.

The Cambrian Bolsa Quartzite is 400 to 700 feet thick and consists dominantly of light gray to brownish gray cross-bedded arkose with lesser quartzite and minor shale. The unit rests unconformably on older Precambrian rocks and sediments of the younger Precambrian Apache Group (Titley, 1982; Heind and McClymonds, 1964).

Conformably overlying the Bolsa Quartzite is the upper Cambrian Abrigo Formation. 1250 feet thick, the unit consists of approximately equal proportions of thin-bedded, fetid limestone and greenish and gray siltstone (Titley, 1982; Graybeal, 1982).

The Devonian Martin Formation unconformbly overlies the older Paleozoic sediments. 300 to 400 feet thick, the Martin Formation is composed of limestone, dolomite, silty carbonate, shale and thin beds of sandstone (Titley, 1982). The shallow marine unit contains brachiopods, gastropods, fishes and ostracods.

Conformably overlying the Martin Formation are 600 to 750 feet of the lower Mississippian Escabrosa Group, consisting of a lower, thin-bedded limestone and an upper massive limestone (Titley, 1982; Bryant, 1968). Corals and brachiopods are reported from Escabrosa outcrops near Tucson (Arizona 
Geological Society, 1952), with crinoids, corals, bryozoans and brachiopods occurring in outcrops in the Vekol Mountains west of the area (Bryant, 1968).

The Paleozoic is poorly known in the southern part of the Wymola GRA due to the effects of contact metamorphism on the dominantly carbonate section. Titley (1982) reports 600 feet of Upper Pennsylvanian Horquilla Formation unconformably overlying the Escabrosa sediments in the Silver Bell area. The lower half of the formation is dominantly thick-bedded carbonate with lesser clastics. The upper half is more thinly bedded with siltstones and shales nearly equaling the amount of carbonates (Titley, 1982).

Conformably overlying and in gradational contact with the Horquilla Formation is the Upper Pennsylvanian to Lower Permian Earp Formation. Averaging 1000 feet thick in southeastern Arizona, the Earp Formation is composed of thin-bedded, pink, ferruginous silty limestone and dolomite with lesser siltstone (Titley, 1982). Paleozoic isopachs of southeastern Arizona indicate that the Paleozoic section in the Wymola area is thinner than average, so the Earp Formation, if present in the GRA, may be much thinner than the thousandfoot average thickness in southeastern Arizona.

Two hundred feet of Lower Premian Colina Formation sediments overly the Earp Formation in the Silver Bell Mountains (Titley, 1982). The contact is apparently conformable. The Colina Formation consists of thick-bedded limestones with very minor dolomite (Titley, 1982).

The Lower Permian Epitaph Formation may overly the Colina Formation in the Wymola GRA. If present, less than 750 feet of dolomite, limestone and cherty, thin-bedded gypsum comprise the Epitaph in the Silver Bell Mountains and surrounding areas (Titley, 1982).

Richard and Courtright (1966) report that sediments previously identified as Cambrian Bolsa Quartzite in the Silver Bell Mountains also resemble 
sediments of the middle Permian Sherrer Formation. The Sherrer Formation consists of lower and upper siltstone and sandstone beds sandwiching 300 feet of silty, carbonate-rich sandstone. Total thickness of the Sherrer Formation is up to 500 feet (Titley, 1982).

The middle Permian Rainvalley and Concha Formations complete the Paleozoic section of southeastern Arizona. The lower Concha Formation consists of thick-bedded limestone and the Rainvalley Formation is composed of thin- to thick-bedded limestone. Both units average 500 feet of thickness in southern Arizona but it is not known if either unit crops out in the Wymola GRA. Although there is much disagreement as to which Paleozoic units exist in the Silver Bell Mountains and surrounding areas, the fact remains that Paleozoic sediments are very important in the area. Intrusion by Laramide igneous rocks, which caused the contact metamorphism making the units difficult to distinguish, resulted in the Paleozoic sediments of the Silver Bell Mountains becoming important hosts of ore in the Silver Bell porphry copper deposits (Richard and Courtright, 1966; Graybeal, 1982; Titley, 1982).

Mesozoic

No Triassic or Jurassic rocks are definitely recognized in the Wymola GRA, but Cretaceous sediments and volcanics crop out in the soutehrn part of the area. Titley (1982) identifies Triassic and Jurassic sedimentary and volcanic rocks as occurring just southwest of the Silver Bell porphyry copper deposit; no other workers report any rocks of Triassic and Jurassic age in the area, although a Laramide alaskite intrusive is misidentified as a preLaramide Mesozoic granitic body on the Arizona state geologic map (Wilson et al., 1969). Alternatively, older Mesozolc units may underlie the Cretaceous sediments in the area and have gone unreported. Titley's (1982) description of the pre-Cretaceous rocks matches other workers' (Richard and Courtright, 
1966) descriptions of Cretaceous sediments, as given below. Titley (1982) also recognized the occurrence of Cretaceous foreland sediments in the Silver Bell Mountains, but does not describe the rocks. Graybeal (1982) describes Mesozoic clastic rocks of the Silver Bell Mountains as well-bedded and well sorted arkose with minor siltstone and pebble conglomerate; color of the clastics varies from buff to maroon. The Mesozoic clastics are intruded by the previously-mentioned alaskite body (Graybeal, 1982) which other workers regard as the earliest Laramide intrusive of the Silver Bell Mountains (Richard and Courtright, 1966). Graybeal's (1982) description of the Mesozoic clastic rocks is similar to Richard's and Courtright's (1966) description of Cretaceous sediments as arkosic sandstone, red shale and conglomerate, of greater than 5000 feet in total thickness. Other workers (Cooper, 1971; Wilson, et al. 1969, Bryant, 1952) correlate the Mesozoic sediments of the Silver Bell Mountains with sediments of known Cretaceous age in the Tucson and Sierrita Mountains. Underlying Cretaceous sediments in both ranges are sediments believed to have been deposited earlier in the Mesozoic (Cooper, 1971 ; Bryant, 1952).

Laramide Orogenic Period

The Laramide was a period of volcanism, intrusion and intense tectonic activity in southern Arizona. It is of particular importance because a large number of porphyry copper deposits were formed at this time, especially in southeastern Arizona (Damon and Mauger, 1966; Shafiqullah et al., 1980; Titley, 1981; Heidrick and Titley, 1982; see fig. 2C). The magmatic and tectonic activity was related to a southeastward sweep of the magmatic arc as the dip of the Benioff zone decreased (Coney and Reynolds, 1977; Clark et al., 1982 ). 
The latest pre-Laramide rocks (Wilson et al., 1969) or earliest Laramide age rocks in the Wymola GRA are andesite flows, breccias and associated lahar deposits (Titley, 1982; Ka unit on fig. 3). Thickness of this volcanic unit, which crops out in the southwestern part of the area, is not reported in the literature.

The oldest Laramide instrusive is an elongate, northwest-trending alaskite stock emplaced along the southwest side of a major pre-Laramide structure (discontinuity 3 of fig. 2C; Richard and Courtright, 1966). The medium- to coarse-grained alaskite contains $54 \%$ weakly perthitic orthoclase, $25 \%$ quartz, $18 \%$ oligoclase, and $2 \%$ biolife, with traces of other minerals (Graybeal, 1982).

Emplacement of the alaskite stock was followed by intrusion of a large sill-like body of dacite porphry. The dacite porphry contains enough potassium feldspar to qualify as a quartz latite, but the name dacite porphyry has been retained by recent workers in order to avoid confusion. This intrusive body contains several large roof pendants of folded and faulted Paleozoic sediments. Andesite porphyries crop out in the same part of the Silver Bell Mountains and either post-date the dacite porphry or represent another phase of the same magma (Graybeal, 1982; Richard and Courtright, 1966). Intrusion of dark colored, strongly porphyritic syenodiorite dikes (Graybeal, 1982) may be related to the dacite and andesite porphyries or may post-date those igneous events.

The latest Laramide event in the Silver Bell Mountains was the intrusion of stocks and contemporaneous dikes of quartz monzonite. The stocks were emplaced parallel to pre-Laramide and Laramide structures but associated dikes cross-cut all earlier structures. The quartz monzonite consists of $44 \%$ andesine, $28 \%$ orthoclase, $20 \%$ quartz, $5 \%$ biotite, $1 \%$ hornblende and accessory 
magnetite, zircon, sphere and apatite. Orthoclase porphyries and biotiterich rocks of the Silver Bell Mountains in the area may represent a younger intrusive phase. The quartz monzonite stocks are extremely important economically as porphyry copper mineralization was associated with that Laramide igneous event.

\section{Metamorphic Core Complexes}

More than a dozen metamorphic core complexes have been identified and described recently in southwestern Arizona. They occur along a northwesttrending zone that extends from southeastern to west-central Arizona and are part of a more extensive zone that runs from Sonora to Arizona, through eastern Nevada, Idaho, eastern Washington and southeastern British Columbia (Coney, 1980). Their general features have been summarized recently by Davis and Coney (1979) and Reynolds (1980) as follows. Metamorphic core complexes are characterized by metamorphic and mylonitic rocks whose gently dipping foliation defines broad domes which generally are elongated in an ENE to NE direction. The core of the domes consist of amphibolite facies gneisses and granites that have undergone ductile deformation. Up section a mylonitic fabric with an ENE-to-NE lineation is overprinted on both igneous and metamorphic rocks. This grades upward into a greenschist facies breccia over a short distance and records a sharp thermal and strain gradient. The breccia is overlain by a normal decollement zone, or dislocation surface, above which allochthonous, deformed, but unmetamorphosed upper plate rocks are present. These range in age from Precambrian to Miocene and have undergone listric normal faulting as recently as mid-Miocene. The core complexes typically record 30 - $20 \mathrm{~m} \cdot \mathrm{y} \cdot \mathrm{B} \cdot \mathrm{P} . \mathrm{K}-\mathrm{Ar}$ cooling ages. It is generally agreed that the complexes formed in an extensional environment (back-arc spreading?) during and after the fast regression of the magmatic arc $40-20 \mathrm{~m} \cdot \mathrm{y} \cdot \mathrm{B} \cdot \mathrm{P}$. (Coney 
and Reynolds, 1977) at a time of high heat flow. Davis and Coney (1979) regard the complexes as megaboudins formed from the crystalline basement. Rehrig and Reynolds (1980) agree that the complexes formed by an extensional process but consider that the metamorphic core complex itself developed between, rather than within, separating blocks.

The Picacho Mountains, including the Picacho Mountains WSA, are considered to be a metamorphic core complex by Johnson (1981), Rehrig and Reynolds (1980) and Banks (1980). Yeend (1976) mapped the range on a reconnaissance level. Information presented below is summarized from those sources. Much of the southern part of the Picacho Mountains is underlain by fairly coarse-grained, locally mylonitic, muscovite-biotite gneiss of apparent meta-igneous origin. Shallow-dipping follation trends northeast. Greenstone and hornblende augen gneiss occur sporadically within the gneiss. Potassiumargon dating of biotite from the gneiss gave a cooling age of $23.6 \pm 0.5 \mathrm{~m} \cdot \mathrm{y}$. To the north, where the Picacho Mountains sharply narrow, the gneiss is intruded by medium-to coarse-grained, equigranular, hornblende monzogranite (Johnson, 1981) or hornblende-biotite granodiorite (Yeend, 1976). The sphenebearing intrusive is rarely foliated and yielded a biotite $\mathrm{K}-\mathrm{Ar}$ age of $24.4 \pm$ $0.5 \mathrm{~m} \cdot \mathrm{y}$. This granodiorite is similar in age and rock type to intrusives which occur in the Durham Hills, Santa Catalina-Rincon Mountains and Tortolita Mountains metamorphic core complexes located southeast of the Picacho Mountains (see fig. 2D).

Overlying the mylonitic gneiss in local areas is schist, dominantly quartz-muscovite schist with lesser chloritic schist, quartzite schist, quartzite, rare siliceous slate, amphibolite schist and quartzite; some are clearly metasedimentary in origin.

The gneiss, granodiorite and schist of the metamorphic core are cut by pegmatite and aplite dikes, felsic dikes, small stocks and dikes of syenite and monzogranite, and andesite dikes. 
Upper plate rocks occur in contact with core rocks only in one small outcropping approximately one-quarter mile southeast of the southeastern corner of the Picacho Mountains WSA. The upper plate rocks are purplish red trachyandesites which are considered correlative with $20.72 \pm 0.50$ to $22.60 \pm$ $0.48 \mathrm{~m} \cdot \mathrm{y}$. old volcanics of Picacho Peak and a smaller hill south of the Picacho Mountains (Shafiqullah et al., 1976). Exxon State (74) No. 1, a wildcat well drilled in Sec. 2, T8S, R8E, about 4 miles west of the northwest corner of the Picacho Mountains WSA in the Picacho basin, bottomed out in quartz diorite gneiss which yielded a K-AR date from biotite of $25 \pm 1.4 \mathrm{~m} \cdot \mathrm{y}$. and a $\mathrm{Rb}-\mathrm{Sr}$ age of (whole rock) of 1,275 and $1,540 \mathrm{~m} \cdot \mathrm{y}$. This gneiss may be a down-faulted portion of the Picacho Mountains metamorphic core indicating that the protolith of the core is Precambrian, possibly the Oracle Granite or equivalent.

In the northern Picacho Mountains the contact between the mid-Tertiary metamorphic core rocks and Precambrian rocks is a fault, the nature of which is undetermined (Yeend, 1976; Johnson, 1981).

A small intrusive body, the North Star stock in the northern Picacho Mountains, was emplaced during the mid-Tertiary orogeny. The stock consists of a coarse-grained, equigranular granite which has been recrystallized and silicified, and a fine- to medium-grained, typically porphyritic monzonite (Johnson, 1981). Biotite from the monzonite yielded a K-AR age of $24.35 \pm$ $0.73 \mathrm{~m} \cdot \mathrm{y} \cdot \mathrm{B} \cdot \mathrm{P}$. (Shafiquallah et al., 1980).

Desert Peak, in the east-central part of the Wymola GRA, consists of mildly foliated quartz diorite which has been intruded along foliation planes by pegmatite and fine-grained quartz monzonite dikes (Banks, 1980). Banks (1980) suggests that Desert Peak is also part of a metamorphic core complex. 


\section{Mid-Tertiary}

Mid-Tertiary rocks are here defined to include all sedimentary and igneous rocks deposited after the Laramide orogeny and the post-Laramide period of peneplanation, and before Basin and Range-type faulting became dominant. These pre-Basin and Range rocks have been divided into three units by Eberly and Stanley (1978) and Scarborough and Wilt (1979, and stratigraphy of the units is summarized in fig. 5.

The lowest unit consists of indurated, red to brown arkosic fluvial sandstone, fanglomerates of gneissic and granitic provenance up to 300 feet thick, and minor lacustrine sediments with some algal limestone. Andesitic to rhyolitic volcanics increase in abundance towards the upper part of this unit.

The middle unit is characterized by voluminous intermediate to felsic volcanism that is associated with the mid-Tertiary orogeny. The volcanics consist of flows, ash flow tuffs, tuff breccias and ash of latitic, quartz latitic, rhyolitic, and trachytic composition and flows and flow breccias of basaltic, basaltic andesite, and andesitic composition (Reynolds, 1980). Small intrusions of the above compositions are also present. The volcanic rocks are interbedded with red sand and gravel fluvial deposits, massive fanglomerates, and lacustrine deposits with local organic-rich facies, algal limestones, and water-laid tuffs. It is within such beds that the well-known uranium deposit of the Anderson Mine is located (Sherborne et al., 1979).

The upper unit consists of grayish brown, poorly consolidated sandstones, fanglomerates, mudstones, and water-laid tuffs. The rocks contain abundant volcanic debris. They are overlain and intercalated with basaltic volcanic mudstones in lacustrine deposits and contain fresh water ostracods. 
PHOENIX-TUCSON AREA

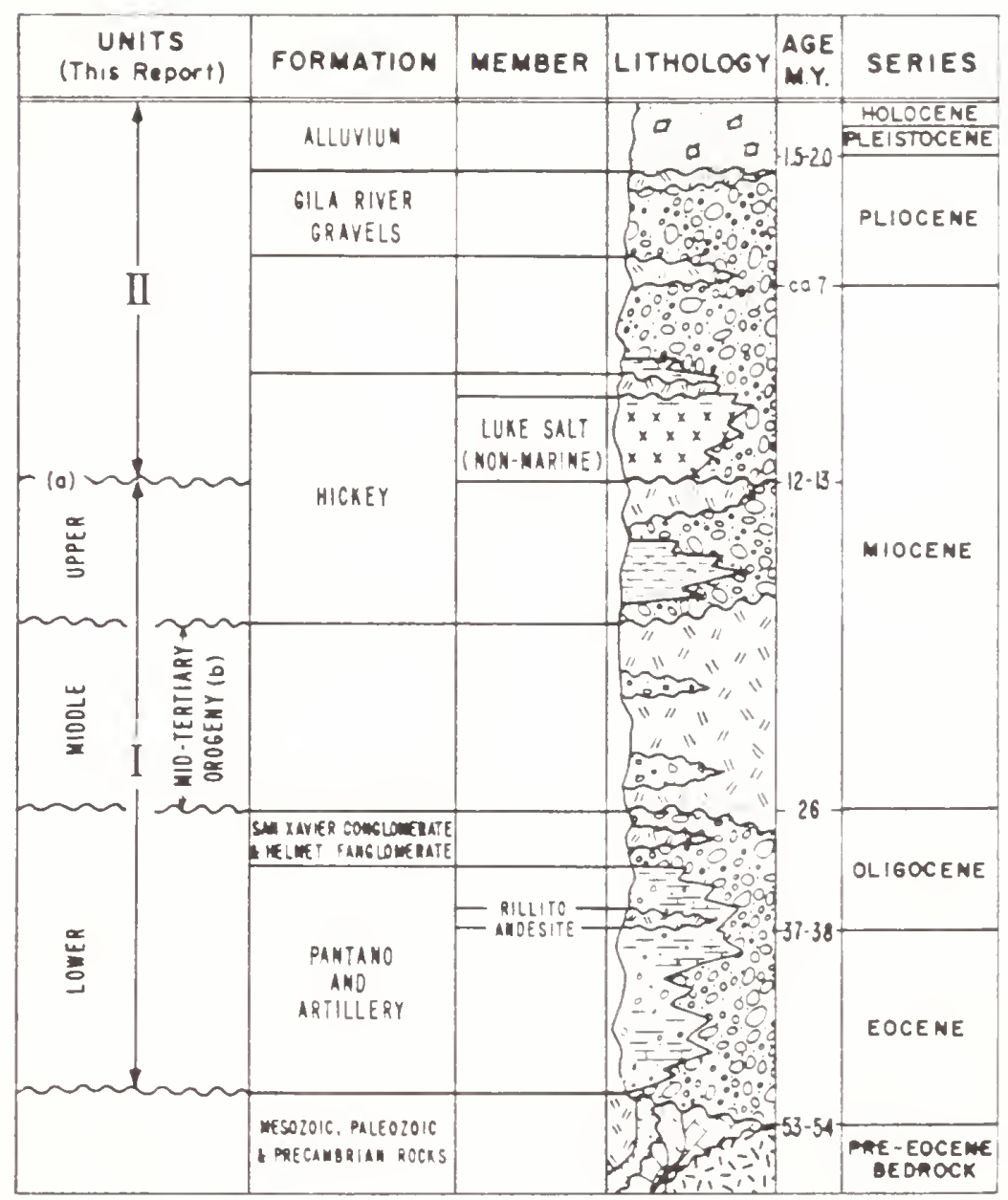

FIG.5 COMPOSITE STRATIGRAPHIC COLUMN OF SOUTHWESTERN ARIZONA. Unconformity (a) represents erosional surface that was disrupted by beginning of late Miocene block faulting. From Eberly and Stanley (1978). 
The mid-Tertiary rocks rest unconformably on Precambrian, Paleozoic, Mesozoic, and Laramide rocks. They were deposited in northwest-striking basins which were tilted northeastward and southwestward as shown in fig. 2D (Scarborough and Wilt, 1979).

The mid-Tertiary volcanic rocks lie mainly in the middle unit, but they do extend into the lower and upper units. The volcanism was extremely voluminous, and in southern Arizona about a million cubic kilometers were emptied (Shafiquallah et al., 1980). These may have been largely emptied from cauldrons such as have been identified in the Datil volcanics in southwestern New Mexico by E1ston (1978) and Elston and Bornhorst (1979). However, no such cauldrons have been identified in southwestern Arizona to date. The volcanism lasted from $35 \mathrm{~m} \cdot \mathrm{y} \cdot \mathrm{B} \cdot \mathrm{P}$. to about $12 \mathrm{~m} \cdot \mathrm{y} \cdot \mathrm{B} \cdot \mathrm{P}$., with the interval between 24 and $12 \mathrm{~m} \cdot \mathrm{y} \cdot \mathrm{B} \cdot \mathrm{P}$. being the transition from the mid-Tertiary orogeny to Basin and Range faulting, which did not take place simultaneously throughout southern Arizona (Shafiqullah et al., 1980). In southeastern Arizona the intensity of volcanism peaked about $26 \mathrm{~m} \cdot \mathrm{y} \cdot \mathrm{B} \cdot \mathrm{P}$. as the volcanic arc swept westward during the steepening of the Benioff zone in the late Oligocene and early Miocene (Coney and Reynolds, 1977) At first the volcanism was calc-alkaline, but as the main magmatic arc passed westward the volcanism became highly potassic with eruption of potassic trachyandesites and ultra-potassic trachytes (Shafiqullah et al., 1980). Towards the close of the mid-Tertiary orogeny, volcanism became almost entirely basaltic.

In the Wymola GRA, mid-Tertiary volcanics and sediments crop out in Picacho Peak and the surrounding area, in the eastern part of the area and throughout the southwestern part of ther area. Rock types include flows, tuffs, breccias, agglomerates, conglomerates and sands. Composition of the volcanics is varied, including basalt, andesite, latite, trachyte, 
and trachyandesite. Andesite, quartz latite and latite dikes cut the Laramide age rocks of the Silver Bell Mountains. Flows are aphanitic to porphyritic; a few are vesicular, with quartz and epidote filling vugs.

Conglomerates are commonly purple or red and contain clasts of pink granite, phyllite, volcanics and gneiss (not similar to the gneiss of Picacho Mountains. Tuffaceous beds are reported to occur in sedimentary sections of the Picacho Peak. The Wymola Conglomerate of Picacho Peak may be correlative with Pantano and Rillito conglomerates of the Tucson area. Conglomerates of the Silver Bell Mountains contain mineralized material derived from the leached cap of the Silver Bell porphyry copper deposit (Graybeal, 1982; Dohms et al., 1980; Shafiqullah et al., 1976; Richard and Courtright, 1966).

Approximately 1100 feet (336 m) of mid-Tertiary sediments and volcanics were encountered during drilling of Exxon's State (74) No. 1 wildcat well in the Picacho Basin.

\section{Late Tertiary}

Late Tertiary deposits occur in all the tectonic basins formed during the Basin and Range disturbance. The depth of these basins have been estimated by Oppenheimer and Sumner (1980) through gravity modeling and drillhole data and is shown in figure 1. The Picacho Basin, in the west-central and northwest of the Wymola GRA, and the Avra Valley, in the southeast, both are greater than 9600 feet deep. The basin in the northeast part of the area is between 6400 and 8000 feet deep.

The deposits consist mainly of poorly consolidated, tan colored fanglomerate, sandstone, and siltstone of fluvial and lacustrine origin, and minor basalt (Scarborough and Wilt, 1979; Eberly and Stanley, 1978). These deposits rest unconformably on mid-Tertiary or older rocks. Exxon's stratigraphic tests from the Exxon State (74) No. 1 will drilled in the Picacho 
Basin reveal that red-brown clay, about 6000 feet of gypsum with lesser halite and green bentonites, and varicolored claystone occur (Eberly and Stanley, 1978; Peirce, 1981, 1976).

The initiation of Basin and Range faulting and deposition of basin-fill sediments took place 13 - $12 \mathrm{~m} \cdot \mathrm{y} \cdot \mathrm{B} . \mathrm{P}$. according to Eberly and Stanley (1978). Shafiqullah et al. (1980), however, present evidence to show that the transition from the mid-Tertiary orogeny to the Basin and Range disturbance took place over the time interval between 19 and $12 \mathrm{~m} \cdot \mathrm{y} \cdot \mathrm{B} \cdot \mathrm{P} \cdot$, and that the basaltic volcanism decreased in intensity from 9 to $4 \mathrm{~m} \cdot \mathrm{y} \cdot \mathrm{B} . \mathrm{P}$. The interval during which Basin and Range tectonism, volcanic activity and sedimentation was dominant in southwestern Arizona was probably $14-4 \mathrm{~m} \cdot \mathrm{y} \cdot \mathrm{B} \cdot \mathrm{P}$. (Shafiqullah et al., 1980), though some basaltic volcanism is as young as $1 \mathrm{~m} \cdot \mathrm{y} \cdot \mathrm{B} . \mathrm{P}$.

Latest Tertiary and Quaternary

During the last four million years volcanic and tectonic activity has slowed down in southwestern Arizona. The dominant geological processes have been erosion of ranges and formation of extensive pediments, deposition of fanglomerates and deposition of alluvium.

\section{Structural Geology}

The GRA lies within the North American craton and east of the Wasatch Line and has been affected by tectonism during Proterozoic, mid-Mesozoic, Laramide and mid-Tertiary orogenies and most recently by the Basin and Range disturbance. The area is, therefore, structurally very complex. It is only recently, and largely as a result of detailed structural studies and extensive radiometric dating, that the structure and tectonics of the area has begun to be understood. Particularly important recent studies include strain analysis of various deformations by Davis (1981) and a summary of recent radiometric dates by Shafiqullah et al., (1980). 
During the Arizonan revolution, 1.76 to $1.63 \mathrm{~b} \cdot \mathrm{y} \cdot \mathrm{B} . \mathrm{P}$. (Damon, 1968), the Precambrian rocks were folded about ENE-striking axes and underwent N-S to NNW faulting (Davis, 1981). The Colorado Lineament (see fig. 2), a major strike slip system according to Warner, was initiated about this time and its southwestern extension passes to the northwest of the GRA.

No pronounced tectonic or igneous activity took place during the Paleozoic, but southwestern Arizona was strongly affected by a mid-Mesozoic magmatic arc and a later period of metamorphism and folding. The magmatic arc extended across southwestern Arizona (see fig. 2C) during mid-Jurassic and produced voluminous volcanism and granitic plutonism. The area underwent folding and metamorphism after deposition of molasse-like sediments and prior to the Laramide orogeny. Northwest-trending strike slip faulting was initiated (Davis, 1981) and movement along the Mojave-Sonora left-lateral megashear (see fig. 2B) probably took place at this time (Silver and Anderson, 1974). Northwest-trending linear discontinuities in depositional patterns (see fig. 2) were produced in southeastern Arizona (Titley, 1976).

The Laramide was a period of intense tectonism and localized magmatic activity which were associated with the southeastward migration of the magmatic arc (Coney and Reynolds, 1977; Lowel1, 1974). The Laramide basementcored uplifts and thrust faults which strike NNW to NW (Nielsen, 1979; Davis 1981); the WNW left-lateral strike slip faulting of the Texas zone of Schmitt (1966); and the ENE-striking tensional features (Rehrig and Heidrick, 1976) are all probably related to ENE plate motion and compression. Laramide plutons associated with porphyry copper mineralization have a pronounced NNW to NW trend and a secondary ENE trend (Heidrick and Titley, 1982; see fig. 2C). The former is parallel to the Laramide magmatic arc and basement-cored uplifts, and the latter is parallel to Precambrian fold axes and Laramide 
tensional features. One of the NE trends and one of the linear discontinuities pass through the southern part of the Wymola GRA (see fig. 2C).

The mid-Tertiary orogeny lasted approximately from 34 to $14 \mathrm{~m} \cdot \mathrm{y} \cdot \mathrm{B} \cdot \mathrm{P}$. (Shafiqullah et al., 1980) and involved eruption of large volumes of volcanic rocks, emplacement of metamorphic core complexes and listric normal faulting. These geologic events accompanied the steepening of the Benioff zone and the resultant westward migration of magmatic arc at this time (Coney and Reynolds, $1977)$.

The volcanism produced enormous volumes of ignimbrite eruptions and was dominantly calc-alkaline but became potassic in the later stages. In southwestern New Mexico similar volcanics originated from numerous cauldrons (Elston and Bornhorst, 1979). Cauldrons may be present in southern Arizona, although none have been located to date.

Metamorphic core complexes are characterized by mylonitic augen gneiss and an overlying brittle fracture zone separated by a dislocation surface from an allochthonous upper plate which is unmetamorphosed (Davis and Coney, 1979; Coney, 1980; Rehrig and Reynolds, 1980). The mylonitic foliation defines gently dipping, NE-to-ENE-striking dunes which often have physiographic expression. The mylonitic rocks have pronounced $\mathrm{NE}-\mathrm{to}-\mathrm{ENE}$ lineation which is developed parallel to the direction of extension in the lower plate. Most workers agree that the metamorphic core complexes indeed formed as a response to extension in a NE-SW to ENE-WSW direction. Davis (1980) considers the complexes as mega-boudins, whereas Rehrig and Reynolds (1980) consider that the complexes developed in areas of high heat flow between separating blocks. The relationship of the core complexes to the coeval volcanism is not known. The Buckeye Hills in the northwest corner of the Estrella sub-area has local mylonitic foliation which is possibly associated with a metamorphic core complex. 
Listric normal faulting is common in the upper plates of metamorphic core complexes. The faults merge downward into the dislocation surface. The spoon-shaped, gravity-like faults generally strike northwest and typically involve Oligocene and mid-Miocene rocks (Davis, 1981). An example is Picacho Peak; the NE tilting volcanics are believed to be listric-faulted upper plate rocks of the Picacho Mountsins metamorphic core complex (Rehrig and Reynolds, 1980; Banks, 1980).

About $14 \mathrm{~m} \cdot \mathrm{y} \cdot \mathrm{B} \cdot \mathrm{P}$. a transition occured between listric faulting and Basin and Range normal faulting. Basin and Range faults strike NW to N-S (see fig. 1) and are high angle faults (Davis, 1981). The present-day ranges and basins resulted from this tectonic episode which was terminated in much of southwestern Arizona about $4 \mathrm{~m} \cdot \mathrm{y} \cdot \mathrm{B} \cdot \mathrm{P}$.

\section{Paleontology}

Fossils are important for three major reasons, as follows:

a) guide fossils which in the sedimentary sequence are most useful for stratigraphic correlation,

b) outstanding fossil specimens or fossils which are extraordinarily well preserved can be beneficial to science and/ or tourism, and

c) fossils can be excellent indicators of the paleogeographic and paleoecological environments; as a result, even moderately to poorly preserved "uninteresting" fossils can be geologically important.

Plant fossils must also be considered important as organic material can trigger the precipitation of uranium and/or other metals. 
The following is a brief summary of the sedimentary formations of the Wymola GRA and WSAs listing types of fossils present. To the authors' knowledge, there are no fossil localities of outstanding importance, either scientifically or as curiosities.

Older metamorphic rocks of the Wymola GRA include the metasedimentary Pinal Schist which was deposited 1.7 to 1.68 b.y.B.P. The Apache Group, of late Precambrian age, includes siltstone and quartzite of the Pioneer Formation; the Dripping Springs Quartzite, which contains siltstone and mudstone beds as well as quartzite; and the Mescal Limestone, a dolomite with siltstone and mudstone beds. To the knowledge of the authors, none of the Precambrian rocks of the Wymola GRA contain any fossils.

Paleozoic fossil-bearing formations crop out in the Wymola area. Trilobites occur in the mid-Cambrian Abrigo Formation (Heindl and McClymonds, 1964). The Devonian Martin Formation contains coalified plant remains, brachiopods, gastropods, fish and ostracods (Teichert, 1965). Crinoids, coral, bryozoans and brachiopods occur in the late Devonian to Mississippian Escabrosa Limestone (Bryant, 1968). No information is available on the paleontology of other Paleozoic formations, that may crop out in the area.

Cooper (1971) and Bryant (1952) report fossils of Cretaceous age in rocks correlative with sediments which crop out in the Silver Bell Mountains, but no fossils are reported.

The lowest mid-Tertiary unit of Scarborough and Wilt (1979) and Eberly and Stanley (1978) contains algal limestone in other areas. The middle midTertiary units of the same groups of authors consist of volcanic rock interbedded with fluvial deposits, fanglomerates and fluvial sands and gravels, fanglomerates and lacustrine deposits including organic-rich beds and algal limestones. No reports of plant or animal fossil occurrences in 
the late Tertiary and Quaternary basin-fill sediments are known to the authors.

The Picacho Mountains WSA (020-194) is underlain by rocks of a metamorphic core complex and a small area of thin Quaternary alluvium which caps a pediment. No fossil occurrences have been reported from the area; it seems unlikely that any exist.

The Ragged Top WSA (020-197) contains outcrops of mostly igneous rocks, but Precambrian Apache Group sediments and Tertiary sediments do crop out. Fossils have not been reported from the Apache Group, but Tertiary sediments in some localities contain algal limestones.

\section{Geologic History}

The geologic history of the area is long and complex, and only a brief synopsis is presented here. Excellent summaries of the main geological events that affected the southern Cordillera of North America are given by Burchfiel (1979) and Dickinson (1981). More detailed accounts pertaining particularly to southern Arizona are given by Titley (1982) and Shafiqullah et al., (1980). The geologic history can be sumarized as follows:

1. 1.8 to 1.6 b.y.B.P. volcanic and clastic rocks were accreted onto the North American Craton from the southeast (Anderson, 1976; Anderson and Silver, 1976; Silver, 1978; Titley, 1982) The boundary between the dominantly volcanic and volcanoclastic Yavapai Series and the clastic nonvolcanic Pinal Schists coincides with the Holbrook Linear which passes to the northwest of the GRA (see fig. 2A). The rocks were folded about northeasterly axes, metamorphosed and intruded by granites 1.7 to 1.6 b.y.B.P. (Damon, 1968), and then intruded by anorogenic granites 1.5 to 1.4 b.y.B.P. (Damon, 1968; Silver et al., 1977 ). 
2. Some time after this, but before $1.2-1.1$ b.y.B.P., the area was uplifted and eroded. The eastern part of the GRA was then submerged beneath epicontinental seas and shallow marine clastic sediments and minor carbonates of the Apache Group were deposited (Heindl and McClymonds, 1964).

3. The Apache Group was intruded by diabase sills and dikes 1.2 to 1.1 b.y.P.B. (Damon, 1968). Locally, the Apache Group is overlain by basaltic rocks of similar age to the intrusives.

4. The area was uplifted and bevelled, and during the Cambrian the GRA was again submerged beneath epicontinental seas. At this time, shallow marine clastic sandstone, mudstone and minor limestone were deposited (Heindl and McClymonds, 1964).

5. No deposition took place during the Ordovician and Silurian, and the Cambrian is disconformably overlain by a thick Devonian to Early Mississippian transgressive sequence of fluvial sandstone, shallow marine clastic rock and dolomitic carbonate rock (Teichert, 1965; Bryant, 1968).

6. Late Paleozoic sediments may or may not occur in the area; possibly they were removed by erosion during the mid-Mesozoic orogeny. Molasse-like Mesozoic sediments were deposited in local basins in the eastern part of the GRA (Heindl, 1965). The upper part of this sequence contains volcanic material, possibly derived from the magmatic arc that extended over the southern part of the GRA during the mid-Jurassic (see fig. 2B).

7. The Laramide was a period of intense tectonic activity characterized by NNW-to-NW-striking basement-cored uplifts 
and thrust faults (Neilsen, 1979; Davis, 1981); WNW-striking, left-lateral faults of the Texas zone (Schmitt, 1966); ENEstriking tensional features (Rehrig and Heidrick, 1976); and intrusion of small epizonal plutons along NW and ENE trends (Heidrick and Titley, 1982). The magmatic activity proceeded from northwest to southeast as the dip of the Benioff zone flattened in the time interval from 70 to $50 \mathrm{~m} \cdot \mathrm{y} \cdot \mathrm{B} . \mathrm{P}$. (Coney and Reynolds, 1977). Several Laramide intrusives crop out in the southern part of the GRA.

8. The Laramide was followed by a period of tectonic quiet and erosion.

9. The mid-Tertiary orogeny lasted from about 35 to $14 \mathrm{~m} \cdot \mathrm{y} \cdot \mathrm{B} . \mathrm{P}$. During this time, a great thickness of fluvial and lacustrine sediments interbedded with voluminous felsic to intermediate volcanics were deposited in northwest-striking basins (Eberly and Stanley, 1978; Scarborough and Wilt, 1979). The volcanism was mainly calc-alkaline (Shafiqullah et al., 1980) and was dominated by ignimbrite eruptions, possibly related to cauldrons. Coeval with the volcanism was the emplacement of metamorphic core complexes which occur along a northwesttrending zone (Coney, 1980) going through the GRA and including the Picacho Mountains in the northern part of the GRA. Associated with the core complexes and also present elsewhere in south Arizona are listric normal faults (Davis, 1981) which offset mid-Tertiary volcanic and sedimentary rocks. Volcanism and tectonism migrated westward during the mid-Tertiary as the dip of the Benioff zone steepened (Coney and Reynolds, 1977). 
10. After the westward passage of the magmatic arc, listric normal faulting gave way to steep, normal Basin and Range faulting which became dominant after $14 \mathrm{~m} \cdot \mathrm{y} \cdot \mathrm{B} . \mathrm{P} . \quad$ (Shafiqullah et al., 1980). At this time basalt became the predominant volcanic rock, the present ranges were uplifted, and the basins were filled with fluvial, lacustrine and marine sediments.

11. Since 4 m.y.B.P. volcanism and tectonism have been minor (Shafiqullah et a1., 1980), and the dominant geologic processes have been erosion of ranges resulting in the formation of extensive pediments and deposition of fans in the basins and alluviun along major rivers.

\section{ENERGY AND MINERAL RESOURCES}

The following are descriptions of known wineral deposits, prospects, occurrences, mineralized areas and thermal wells and other energy resources (fig. 3) of the Wymola GRA. Information was derived from the following sources: U.S. Geological Survey (1982, entries dated 1981, 1980, 1979, 1977, 1976, 1973, 1972; CRIB), witcher et a1., (1982), Johnson (1981), Eber1y and Stanley (1978), Yeend (1976), Arizona Bureau of Mines (1969), Stipp et al. (1967), Richard and Courtright (1966) and McCrory and O`Haire (1965). Also consulted, but found not to contain applicable information, were Union Carbide Corporation (1982 - NURE HSSR data), Scarborough and Wilt (1979), Texas Instruments, Incorporated (1978; 1975 - NURE) and Johnson (1972).

The following descriptions represent a summary of the information about individual mines and occurrences that is available to the authors. Figure 3 illustrates locations of the listed mines, mineral occurrences and energy resources. 
Known Mineral Deposits, Mines or Prospects with Recorded Production

11. Magdnigal Mine

Synonym Name:

Location:

$32025^{-32} 32 \mathrm{~N}, 111^{\circ} 37-35 " \mathrm{~W}$

Sec. 34, TI1S, R7E

Commodities:

$\mathrm{Cu}, \mathrm{Au}$ (major), $\mathrm{Pb}, \mathrm{Mo}, \mathrm{Mn}$ (minor)

Ore Materials:

Chrysocolla, chalcopyrite, chalcocite, pyrite (main), wulfenite, manganese oxide, malachite (?) (minor).

Deposit Description: Disseminated deposit in shear zone, small deposit with surface and underground workings.

Geology: Mineralization in Cretaceous sediments and andesitic volcanics.

Production: Yes, small amount.

References: USGS, 1979, CRIB Mineral Resources File 12, Record 1006, p. 2638-2640, Stipp et.al., 1967.

15. Unnamed Prospect VHNE-029N

Location:

$32023-9 " \mathrm{~N}, 111030-39 " \mathrm{~W}$

Sec. 14, TIIS, R8E

Commodities: $\mathrm{Au}$ (major), $\mathrm{Cu}$ (occurrence)

Deposit Description:

Geology:

Production:

Small vein deposit, striking $N 750^{\circ}$.

Underground workings.

In Tertiary red beds.

References:

Yes, small amount.

USGS, 1976, CRIB Mineral Resources File 12, Record 1010, p. 2647-2648.

19. Grand Mogul

Location:

$32027-57 \cdots \mathrm{N}, \quad 111032-32 \cdots \mathrm{W}$

NW1/4 NWl/4 Sec. 21, I11S, R8E

Commodities:

$\mathrm{Pb}$ (major), $\mathrm{Ag}, \mathrm{Cu}, \mathrm{Au}$ (minor)

Deposit Description: Metasomatic lenses and pods. Surface workings.

Geology:

Mineralization in Paleozoic limestone.

Production:

Yes, small amount.

References:

USGS, 1981, CRIB Mineral Resources File 12, Record 1014, p. 2655-2656.

20. New Hope Mine

Location:

$32018-16 " \mathrm{~N}, 111^{\circ 0}-34^{\prime \prime W}$

NW $1 / 4 \mathrm{Sec} .21, \mathrm{~T} 11 \mathrm{~S}, \mathrm{R} 8 \mathrm{E}$

Commodities:

$\mathrm{Cu}$ (major), $\mathrm{Ag}$ (minor)

Deposit Description: Metasomatic lenses and pods. Surface workings.

Geology:

Mineralization in Paleozoic limestone.

Production:

Yes, small amount.

References:

USGS, 1981, CRlB Mineral Resources File 12,

Record 1015, p. 2657-2658.

23. Unnamed Prospect VHNE-051N
Location:
$322^{\circ} 27^{-38 * N,} 111^{\circ} 32^{\prime \prime} 13^{\prime \prime} \mathrm{W}$
Sec. 21, TIIS, R8E
Comriodities:
$\mathrm{Pb}, \mathrm{W}, \mathrm{V}, \mathrm{Cu}$ (trace)
Ore Materials:
Wulfenite, Vanadinite. 
Deposit Description: Snall, trending N850W, dipping $55{ }^{\circ}$ S vein with unknown workings.

Geology: Agglomerate and welded tuff of Tertiary (?) Mount Lord volcanics.

Production: Yes, small amount.

References: USGS, 1976, CRIB Mineral Resources File 12, Record 1018, p. 2663-2664.

25. Rigueza Claims

Location:

$32027-4 " \mathrm{~N}, 111030-7 \mathrm{~W}$

Sec. 23, Tl1S, R8E

Commodities:

$\mathrm{Cu}, \mathrm{Pb}, \mathrm{Zn}$

Ore Materials:

Sphalerite, galena, chalcopyrite.

Deposit Description:

Geology:

Small disseminated-fissures type deposit, Workings--prospects, short adits.

Production:

Mineralization in granodiorite porphyry, Cretaceous--Tertiary.

References:

Yes, two carloads.

USGS, 1976, CRIB Mineral Resources File 12, Record 1020, p. 2667-2668.

30. North Silverbell Mine
Location:
$32{ }^{\circ} 26^{-2} 27^{* N}, 111^{\circ} 31^{-5} 57^{\prime \prime} \mathrm{W}$
Sec. 28, T11S, R8E
Commodities:
$\mathrm{Cu}$ (najor); Mo (occurrence)
Ore Materials:
Chalcocite, chalcopyrite, oxide copper minerals.
Deposit Description: Small, irregular oval elongate NW shape in a disseminated-fracture type deposit, surface and underground workings.
Geology:
Mineralization in Cretaceous quartz latite porphyry.
Production:
Yes, small amount.
References:
USGS, 1976, CRIB Mineral Resources File 12, Record 1025, p. 2677-2678.

33. Silver Lead Mine Group

Location:

Commodities:

Ore Materials:

Deposit Description:

Geology:

Production:

References:

37. Atlas Mine

Location:

Commodities:
$32 \circ 26^{\prime} 16^{\prime \prime} \mathrm{N}, 111^{\circ} \mathrm{32} 2^{\prime} 18^{\prime \prime} \mathrm{W}$

Sec. 28, T11S, R8E

$\mathrm{Pb}, \mathrm{Zn}, \mathrm{Cu}, \mathrm{Ag}$

Base metal sulphides.

Snall, largely oxidized, spotty in a pyrometosomatic type deposit, underground workings. Mineralization in Paleozoic limestone associated with Cretaceous-Tertiary granitic intrusive; limestone block along a fault contact with Laramide intrusive.

Yes, 130 tons.

USGS, 1979, CRIB Mineral Resources File 12, Record 1028, p. 2683-2685.

$32025-47 " \mathrm{~N}, 111032-46 " \mathrm{~W}$

Sec. 32, Tl1S, R8E

$\mathrm{Zn}, \mathrm{Cu}$ (major); $\mathrm{Ag}, \mathrm{Au}, \mathrm{Pb}$ (minor) 
Ore Materials: Chalcopyrite, bornite, sphalerite.

Deposit Description: Medium trending ENE, dipping $63^{\circ} \mathrm{SE}$, many ore shoots are present and are stopped; mantos, pods and lenses in pyrometasomatic replacement, underground workings.

Geology : Mineralization in Paleozoic quartzite and linestone associated with Laramide alaskite, dacdacite porphyry and monzonite porphyry.

Production: Yes, medium amount--147,500 tons.

References: USGS, 1981, CRIB Mineral Resources File 12, Record 1032, p. 2692-2694.

53. Ramero Ranch

Location:

$32{ }^{\circ} 19^{-} 39^{\circ} \mathrm{N}, 111^{0} 30^{\circ} 19^{\prime \prime} \mathrm{W}$

Sec. 2, T12S, R8E

Conmodities:

$\mathrm{Cu}, \mathrm{Au}$ (major); $\mathrm{Ba}$ (occurrence)

Ore Materials:

Malachite, barite, azurite, native gold, chalcopyrite, bornite.

Deposit Description: Small, shear zone, underground workings. Geology:

Production:

Mineralization in Tertiary sediments.

References:

Yes, small amount. USGS, 1976, CRIB Mineral Resources File 12, Record 1064, p. 2768-2769.

55. Mamoth Mine/0ld Boot, Imperial, Union

Location:

Commodities:

Ore Materials:

Deposit Description:

Production:

References:
Geology:

$32024-52 " \mathrm{~N}, 111031-45 " \mathrm{~W}$

$\mathrm{Sec} \cdot$ 4, T12S, R8E

$\mathrm{Cu}, \mathrm{Ag}$ (najor); $\mathrm{Pb}, \mathrm{Zn}, \mathrm{Au}$ (minor); $\mathrm{Mo}$ (potential); F, Ba (occurrence)

Chalcopyrite, $\mathrm{Pb}$ and $\mathrm{Zn}$ carbonates and sulphides.

Small; fissure veins, irregular disseminations in a pyrometasomatic type deposit; underground workings. Mineralization in Paleozoic linestone associated with Cretaceous-Tertiary dacite porphyry monzonite.

At least 45,000,000 1bs. Cu produced. USGS, 1979, CRIB Mineral Resources File 12, Record 1066, p. 2772-2774; Arizona Bureau of Mines Bull. 180, 1969; Richard and Courtright, 1966.

56. Silver Bell Copper/Silver Bell Mill

\section{Location:} $32025^{\prime} 13^{\prime \prime} \mathrm{N}, 111032^{\prime} 25^{\prime \prime} \mathrm{W}$

Sec. 4, 11, T12S, R8E

Commodities:

$\mathrm{Cu}$ (major); $\mathrm{Pb}, \mathrm{Zn}, \mathrm{Mo}, \mathrm{Au}, \mathrm{Ag}$ (minor); $\mathrm{Bi}$, Cd (occurrence)

Ore Materials: Chalcopyrite associated with pyrite, chalcocite. Deposit Description: chalcocite with minor chalcopyrite, also contact replacement-type ore deposits in Cretaceous sediments, flat tabular ore bodies; surface workings. 
Geology:

Production:

References:

68. Indiana-Arizona

Location:

Commodities:

Ore Materials:

Deposit Description:

Geology:

Production:

References:
Mineralization in Laramide alaskite, dacite porphyry and monzonite.

Yes, large amount.

USGS, 1977, CRIB Mineral Resources File 12, Record 1067, p. 2775-2776; Arizona Bureau of Mines Bull. 180, 1969, Richard and Courtright, 1966.

$32021^{-2} 21^{\prime \prime N}, 111028-42 " \mathrm{~W}$

Sec. 25, T12S, R8E

$\mathrm{Cu}, \mathrm{Pb}, \mathrm{Zn}, \mathrm{Ag}, \mathrm{Au}$

Sulfide and carbonates.

Small, trending E-NE, large lenses of high grade chalcopyrite ore in a vein/shear zone, underground workings.

Mineralization in Paleozoic limestone.

Yes, small amount.

USGS, 1981, CRIB Mineral Resources File 12, Record 1079, p. 2799-2800, Stipp et. al., 1967.

71. Silver Hill Mine Group

Location:

Commodities:

Ore Materials:

Deposit Description:

Geology:

Production:

References:

72. Twin Hill Prospect

Location:

Commodities:

Ore Materials:

Deposit Description:

Geology:

Production:

References:

73. Sunset Group

Location:

Commodities:

Ore Materials: $32^{\circ} 20^{\prime} 52^{\prime \prime} \mathrm{N}, 111^{\circ} 28^{\prime} 19^{\prime \prime} \mathrm{W}$

Sec. 31, T12S, R9E

$\mathrm{Cu}, \mathrm{Ag}, \mathrm{Pb}$ (major); $\mathrm{Au}$ (minor)

Copper and lead carbonates and sulphides.

Small, lensing in a replacement/veins/shear zone, underground workings.

Mineralization in Paleozoic limestone and quartzite associated with Cretaceous-Tertiary granitic intrusives.

Yes, small amount.

USGS, 1981, CRIB Mineral Resources File 12, Record 1082, p. 2805-2807, Stipp et. al., 1967.

$32021^{\prime} 4^{\circ \mathrm{N},} 111^{\circ} 11^{-5} 58^{\circ \mathrm{W}}$

Sec. 34, T12S, R1IE

$\mathrm{Pb}, \mathrm{Zn}, \mathrm{Ag}, \mathrm{Cu}$

Lead-zinc carbonate, copper silicate.

Small, trending $\mathrm{N}_{4} \mathrm{O}_{\mathrm{W}}$; lenses, veinlets, vugs in a replacement; surface workings. Mineralization in Paleozoic limestone and in Precambrian Pinal schist.

Yes, small amount - 40 tons.

USGS, 1979, CRIB Mineral Resources File 12, Record 1083, p. 2808-2810.

$320^{\circ} 25-40 " \mathrm{~N}, 111^{\circ} 37^{\circ} 55^{\prime \prime} \mathrm{W}$

Sec. 34, T11S, R7E

Mn (major); Cu (occurrence)

Psilomelane with minor softer oxides of manganese, $\mathrm{Cu}$ oxides. 
Deposit Description: Small, trending northwest, dipping 6005W, ore body parallels bedding in limestone and terminates on northwest side of $N 40^{\circ} \mathrm{E}$

trending fault; lens in a replacement/vein, surface and underground workings.

Geology:

Mineralization in limestone associated with

Production:

Cretaceous or Tertiary porphyry dike.

References:

Yes, small amount.

USGS, 1972, CRIB Mineral Resources File 12, Record 1308, p. 3454-3456.

74. El Tiro Open Pit Mine/ Red Rock Group, Silver Bell Mine

\section{Location:}

Comodities:

Ore Materials:

Deposit Description:

Geology:

Production:

References:
$32024^{-58} " \mathrm{~N}, 111032^{\prime \prime} 13^{\circ} \mathrm{W}$

Sec. 4, T12S, R8E

$\mathrm{Cu}$ (major); $\mathrm{Mo}, \mathrm{Ag}, \mathrm{Pb}, \mathrm{Au}$ (minor)

Pyrite, chalcopyrite (primary); chalcocite (secondary); cuprite or limonite in leached capping.

Large; tabular in porphyry copper, ore in thin quartz-sulfide veinlets but aggregate thickness of many rake a disseminate type. Mineralization in Laramide monzonite and Paleozoic sediments associated with CretaceousTertiary alaskite, dacite porphyry.

Yes, large amount.

USGS, 1973, CRIB Mineral Resources File 12, Record 1324, p. 3493-3495; Arizona Bureau of Mines Bull. 180, 1969, Richard and Courtright, 1966.

75. Oxide Open Pit Mine/Young American, Silver Bell Mine

Location:

Commodities:

Ore Materials:

Deposit Description:

Geology :

Production:

References: $32^{\circ} 23^{-4} 49^{\circ} \mathrm{N}, 111^{\circ} 30^{-} 7 \mathrm{w} \mathrm{W}$

Sec. 11, T12S, R8E

$\mathrm{Cu}$, Ilo, Au

Pyrite, chalcopyrite (primary); chalcocite (secondary); cuprite or limonite in leached capping .

Large, tabular in porphyry copper; ore in thin quartz-sulfide veinlets but aggregate thickness of many make a disseminated type. Mineralization in Laramide monzonite associated with Cretaceous-Tertiary alaskite, dacite porphyry..

Yes, large amount.

USGS, 1973, CRIB Mineral Resources File 12, Record 1325, p. 3496-3498, Stipp et. al., 1967, Richard and Courtright, 1966.

81. Arizona Portland Cement

Location:

Commodity:

Ore Material:

Geology:

Production:

References:
Sec. 34, T12S, R11E

Limestone for cement

Limes tone.

Escabrosa and Naco Group limestone.

Yes.

Stipp et. al., 1967; Arizona Bureau of Mines Bul1. 180, 1969. 
154. Better Pay

Location:

Sec. 22, T9S, R9E

Commodity:

Location very approximate

Production:

$\mathrm{Pb}$

References:

27 tons of ore shipped in 1940.

Arizona Bureau of Mines Bull. 180, 1969.

Known Prospects, Mineralized Areas, and Geothermal

Resources With No Recorded Production

1. Unnamed Prospect

Location:

Commodity:

Ore Materials:

Deposit Description:

Geology:

Production:

References:

2. North Star Mine

Location:

Commodity:

Ore Materials:

Deposit Description:

Geology:

Production:

References:

3. Sundown

Location:

Commodities:

Ore Materials:

Deposit Description:

Geology:

Production:

References:

4. Gold Bell

Location:

Commodities:

Production:

References:
$32031-9 " \mathrm{~N}, 111040-46 " \mathrm{~W}$

Sec. 30, T10S, R7E

$\mathrm{Cu}$

Malachite, chrysocolla, chalcocite (?), limonite.

Vein, with sericitic alteration, small body 10-20 feet in width, striking $N 75 \%$.

Quartz vein cutting Precambrian granite.

Unknown.

USGS, 1979, CRIB Mineral Resources File 12, Record 1666, p. 4316-4317.

$32049-31 " \mathrm{~N}, 111^{\circ} 20^{-} 32 \mathrm{~W}$

Sec. 7, 8, T7S, RIOE

$\mathrm{Cu}$

Chrysocolla, malachite, chalcocite, chalcopyrite.

Snall, striking $N 40^{\circ}$ to $N 60 \mathrm{OW}$, dipping 30-40\% $\mathrm{SW}$.

Granite, dikes, sills of monzonite, dacite, and andesite porphyry.

Unknown.

USGS, 1972, CRIB Mineral Resources File 12, Record 1746, p. 4483-4484, Johnson, 1981.

Sec. 3, T10S, R11E

$\mathrm{Cu}, \mathrm{Ba}$

Tenorite, Azurite, malachite, chalcopyrite, chrysocolla, barite.

Vein.

Quartz barite veins in Tertiary sediments. Unknown.

USGS, 1976, updated 1981, CRIB Mineral

Resources File 12, Record 1855, p. 4737-4738.

$32043^{-7} " \mathrm{~N}, 111^{\circ} 22^{\prime} 19^{\prime \prime} \mathrm{W}$

$\mathrm{NW} 1 / 4 \mathrm{NW} 1 / 4 \mathrm{sec} \cdot 24$, T8S, R9E

Unknown, may be copper.

Unknown.

USGS, 1973, CRIB Mineral Resources File 12, Record 1912, p. 4850, Johnson (1981). 
5. Unnamed Prospect VHNE-028N

Location:

Commodities:

Deposit Description:

Geology:

Production:

References:

6. Sunset Claims

Location:

Commodities:

Ore Materials:

Deposit Description:

Geology:

Production:

References: $320^{\circ} 22^{-39 " \mathrm{~N},} 111^{\circ} 30^{\circ} 19^{\prime \prime} \mathrm{W}$

$\mathrm{SW} 1 / 4, \mathrm{sec} \cdot 14, \mathrm{~T} 12 \mathrm{~S}, \mathrm{R} 8 \mathrm{E}$

Unknown.

Disseminated, fractures, propylitic

alteration.

Mineralization in Cretaceous (?) red beds.

No.

USGS, 1976, CRIB Mineral Resources File 12, Record 974, p. 2567-2568.

$32025^{-4} 43^{\prime \prime} \mathrm{N}, 111^{\circ} 38^{\circ} \mathrm{W}$

Sec. 33, T11S, R7E

$\mathrm{Cu}, \mathrm{Mn}$

Copper carbonates, chrysocolla, manganese

oxides.

Dike intruded along fault.

In Tertiary-Cretaceous granodiorite porphyry. Unknown.

USGS, 1976, CRIB Mineral Resources File 12, Record 982, p. 2583-2584.

7. Unnaned Prospect VHNW-014N

Location:

$32027-38^{\prime \prime} \mathrm{N}, 111^{\circ} 38^{-12} 1 \mathrm{w}^{\circ}$

Commodity:

Sec. 22, T11S, R7E

Chrysocolla, chalcocite, malachite.

Deposit Description: Disseminated, fractures, small deposit.

Geology:

Production:

References:

Mineralization in welded tuff.

None.

USGS, 1976, CRIB Mineral Resources File 12, Record 1002, p. 2630-2631.

8. Unnamed Prospect VHNE-124N

Location:

$32026^{-34} " \mathrm{~N}, 111^{\circ} 36^{-00} \mathrm{\prime W}$

Sec. 25, TI1S, R7E

Commodity:

$\mathrm{Cu}$

Ore Materials:

Chrysocolla, chalcopyrite.

Deposit Description: Disseminated, fracture/vein small deposit.

Geology:

Production:

Mineralization in Cretaceous volcanics.

None.

References: $\quad$ USGS, 1976, CRIB Mineral Resources File 12, Record 1003, p. 2632-2633.

9. Unnamed Prospect VHNE-125N

Location:

Commodity:

Ore Materials:

Deposit Description:

Geology:

Production:

References: $320^{\circ} 26^{-3} 38^{\prime \prime} \mathrm{N}, 111^{\circ} 35^{-5} 56^{\prime \mathrm{W}}$

Sec. 25, T11S, R7E

$\mathrm{Cu}$

Chrysocolla, chalcocite.

Stnall, disseminated deposit.

Mineralization in Cretaceous welded tuff.

None.

USGS, 1976, CRIB Mineral Resources File 12, Record 1004, p. 2634-2635. 
10. Unnained Prospect VHNE $-127 \mathrm{~N}$

Location: $\quad 32026^{-5} 53^{\prime \prime N}, 111^{\circ} 35^{-5} 55^{\prime \prime W}$

Commodity: $\quad \mathrm{Cu}$

Ore Materials: Chrysocolla, azurite.

Deposit Description: Small disseminated deposit with underground workings.

Geology: Mineralization in Cretaceous volcanics.

Production: None.

References: USGS, 1976, CRIB Mineral Resources File 12, Record 1005, p. 2636-2637.

12. Unnamed Prospect VHNE-007R

Location:

$320^{\circ} 25-40 \mathrm{~N}, 111^{\circ} 37-55^{\mathrm{NW}}$

$\mathrm{SE} 1 / 4 \mathrm{sec} \cdot 33$, T11S, R7E

Commodity:

$\mathrm{Cu}$

Ore Materials: Chrysocolla, chalcopyrite, pyrite.

Deposit Description: Small disseminated deposit.

Geology:

Production:

Mineralization in Paleozoic limestone.

References:

Unknown.

USGS, 1976, CRIB Mineral Resources File 12, Record 1007, p. 2641-2642.

12. Unnamed Prospect VHNW-008R

Location:

$32025^{-52} \mathrm{wN}, 111^{\circ} 38^{-23} \cdot \mathrm{W}$

Commodity:

Sec. 34, T11S, R7E

Ore Materials:

$\mathrm{Cu}$

Deposit Description:

Geology:

Production:

Chrysocolla, tenorite, chalcopyrite.

References:

Small disseminated deposit.

Mineralization in Permian limestone.

Unknown.

USGS, 1976, CRIB Mineral Resources File 12, Record 1008, p. 2643-2644.

14. Unnamed Prospect VHNE-043N

Location:

$32{ }^{\circ} 28-52 " \mathrm{~N}, 111030^{-17} " \mathrm{~W}$

Sec. 11, T11S, R8E

Commodity:

Mn

Ore Materials:

Coronadite (?) or hollandite.

Deposit Description:

Geology:

Production:

Small vein deposit, 1 foot in width, striking $\mathrm{N}^{\circ} 0^{\circ} \mathrm{E}$.

References:

Mineralization in Tertiary basalt.

None.

USGS, 1976, CRIB Mineral Resources File 12, Record 1009, p. 2645-2646.

16. Unnamed Prospect VHNE $-044 \mathrm{~N}$

Location:

Commodity:

Deposit Description:

Geology:

Production: $320^{\circ} 8^{-} 2 " \mathrm{~N}, 111^{\circ} 30^{-} 34^{\prime \prime} \mathrm{W}$

Sec. 15, Tl1S, R8E

$\mathrm{Cu}$

Snall deposit, associated with alteration along dike.

Associated with diabase intruding Precambrian granite.

None. 
References:

USGS, 1976, CRIB Mineral Resources File 12, Record 1011, p. 2649-2650, Stipp et. al., 1967.

17. Unnamed Prospect VHNE-068N

Location:

$32028-25 " \mathrm{~N}, 111032-26 \mathrm{~W}$

Sec. 16, TIlS, R8E

Commodities:

$\mathrm{Pb}, \mathrm{Cu}, \mathrm{Zn}$ (occurrence)

Ore Materials:

Galena, malachite, chrysocolla, sphalerite.

Deposit Description:

Geology:

Small deposit in shear zone.

Production:

Mineralization in Precambrian granite.

None.

References:

USGS, 1976, CRIB Mineral Resources File 12, Record 1012, p. 2651-2652.

18. Unnamed Prospect VHNE-072N

Location:

Commodity:

Ore Materials:

Deposit Description:

Geology:

Production:

References:
$32027^{-2} 22^{\prime N} \mathrm{~N}, 111^{\circ} 33^{\prime} 10^{\circ} \mathrm{W}$

Sec. 20, T11S, R8E

$\mathrm{Cu}$

Chalcocite.

Sall deposit, boxwork chalcocite.

Mineralization in Cretaceous sediments.

None.

USGS, 1976, CRIB Mineral Resources File 12, Record 1013, p. 2653-2654.

21. Unnamed Prospect VHive-036N

Location:

$32027-5 \cdots \mathrm{N}, 111032-2 " \mathrm{~W}$

$\mathrm{Sec} \cdot 21$, T11S, R8E

Commodities:

$\mathrm{Cu}, \mathrm{Pb}, \mathrm{Zn}$.

Ore Materials:

Chalcopyrite, sphalerite, galena.

Deposit Description:

Geology:

Production:

References:

Disseminated fractures. Underground workings.

Mineralization in Cretaceous volcanics.

None.

USGS, 1976, CRIB Mineral Resources File 12, Record 1016, p. 2659-2660.

22. Unnamed Prospect VHNE-062N

Location:

$32027^{-2} 20^{\circ} \mathrm{N}, 111^{\circ} 31^{-5} 50^{\prime \prime} \mathrm{W}$

Sec. 21, T11S, R8E

Commodities:

$\mathrm{Pb}, \mathrm{Cu}, \mathrm{Zn}, \mathrm{Ag}$

Ore Materials:

Galena, cerussite, malachite-sphalerite boxwork.

Deposit Description:

Smal1, trending $\mathrm{N} 67^{\circ} \mathrm{E}$, dipping $70^{\circ} \mathrm{S}$,

fracture disseminated type deposit, underground workings.

Geology:

3 minor adits on minor fault with quartzsericite-pyrite-galena-sphalerite, copper showings in dump as malachite.

Production: None.

References:

USGS, 1976, CRIB Mineral Resources File 12, Record 1017, p. 2661-2662. 
24. Unnamed Prospect VHNE-050N

Location: $\quad 32{ }^{\circ} 27^{-} 50^{\prime \prime} \mathrm{N}, 111^{\circ} 30^{-} 44^{\mathrm{W}} \mathrm{W}$

Commodity:

Sec. 22, TIIS, R8E

Ore Materials: Chrysocolla, malachite-chalcopyrite and chalcocite boxwork.

Deposit Description: Small, disseminated-fracture type deposit. Geology: Mineralization in Precanbrian (?) diabase associated with Cretaceous-Tertiary quartz monzonite porphyry; whole area has "live" limonite colors; some of the alteration in diabase may be potassic.

Production: None.

References: $\quad$ USGS, 1976, CRIB Mineral Resources File 12, Record 1019, p. 2665-2666.

26. Unnamed Prospect VHNE-139N

Location:

$32 \circ 26-52 \mathrm{~N}, 111030-47 \mathrm{~W}$

Sec. 27, TI1S, R8E

Comodity:

$\mathrm{Cu}$

Ore Materials:

Malachite.

Deposit Description: Small, tabular shaped in a fracture-

disseminated type deposit, surface workings.

Geology:

Mineralization in granodiorite porphyry associated with Cretaceous-Tertiary finegrained dike.

Production: None.

References: $\quad$ USGS, 1976, CKIB Mineral Resources File 12, Record 1021, p. 2669-2670.

27. Unnamed Prospect VHNE-137N

Location: $\quad 32026^{-} 22^{\prime \prime} \mathrm{N}, 111^{0} 30^{\prime} 55^{\prime \prime} \mathrm{W}$

Sec. 27, T11S, R8E

Commodity: $\quad \mathrm{Cu}$

Ore Materials: Malachite (sulfide boxwork).

Deposit Description: Small, disseminated-fracture type deposit, unknown developments.

Geology:

Production: Mineralization in Laramide quartz latite porphyry.

References: $\quad$ USGS, 1976, CRIB Mineral Resources File 12, Record 1022, p. 2671-2672.

28. Unnamed Prospect VHNE-138N

Location:

$32026^{-52} \mathrm{~N} \mathrm{~N}, 111030^{-40 " \mathrm{~W}}$

Sec. 27, T11S, R8E

Commodity:

$\mathrm{Ba}$

Ore Materials:

Barite.

Deposit Description: Geology:

Suall, vein type, underground workings. Mineralization in Cretaceous-Tertiary granodiorite porphyry; coarse barite with quartz gangue in dump. Overall propylitic alteration of rhyodacite, spotty light pyrite stains in area. 
Production: None.

References: USGS, 1976, CRIB Mineral Resources File 12, kecord 1023, p. 2673-2674.

29. Scott Claims

Location:

Commodities:

Ore Naterials:

Sec. 28, TIIS, R8E

$\mathrm{Cu}, \mathrm{Pb}, \mathrm{Zn}, \mathrm{W}, \mathrm{F}$

Chrysocolla, wulfenite, galena, sphalerite boxwork, fluorite.

Deposit Description: Small, trending N300E, dipping 650W-faulting, disseminated-veinlet type deposit, surface workings - 4-5 prospects and trench.

Geology:

Mineralization in Cretaceous-Tertiary

granodiorite porphyry; vein fractured quartzose intrusive, veins of fluorite, galena, sphalerite, also quartz (vuggy) + pyrite veinlets, overall alteration is propylitic but sericite occurs = adjacent to quartzpyrite veins.

Production:

None.

References: $\quad$ USGS, 1976, CRIB Mineral Resources File 12, Record 1024, p. 2675-2676.

31. Unnamed Prospect VHNE-076N

Location:

$32026^{-2} 22^{\prime \prime N}, 111032-32 " \mathrm{~W}$

Sec. 28, TIIS, R8E

Commodities:

$\mathrm{Cu}$, Mo

Ore Materials:

Chalcopyrite, molybdenite.

Deposit Description:

Geology:

Small, disseminated-fracture type deposit, surface workings--drill hole tailings.

Mineralization in Laramide quartz latite; heavy quartz sericite-pyrite with abundant moly and light amounts of chalcopyrite in drill hole tailings.

Production: None.

References: USGS, 1976, CRIB Mineral Resources File 12, Record 1026, p. 2679-2680.

32. Unnamed Prospect VHNE-035N
Location:
$32026^{-} 60^{\circ} \mathrm{N}, 111^{\circ} 32^{\prime} 11^{\prime \prime} \mathrm{W}$
Commodity:
Sec. 28, TllS, R8E
Ore Materials:
$\mathrm{Cu}$
Deposit Description:
Copper stains.
Small, trending $N 50^{\circ} \mathrm{E}$, dipping steeply, disseminated-fractures type deposit.
Geology:
Mineralization in Cretaceous Mount Lord
Production: volcanics.
References:
None.
USGS, 1976, CRIB Mineral Resources File 12, Record 1027, p. 2681-2682. 
34. Unnamed Prospect VHNE-023N

\begin{tabular}{|c|c|}
\hline Location: & $\begin{array}{l}322^{\circ} 6^{-} 27^{\prime \prime} \mathrm{N}, 111035^{\prime} 10^{\prime \prime} \mathrm{W} \\
\text { Sec. 30, TIIS, R8E }\end{array}$ \\
\hline Commodity: & Unknown \\
\hline Ore Materials: & Unknown. \\
\hline Deposit Description: & $\begin{array}{l}\text { Small, trending } \mathrm{N}^{\circ} 60^{\circ} \mathrm{W} \text {, dipping } 58 \mathrm{O}_{\mathrm{NE}} \text {, } \\
\text { three prospect pits. }\end{array}$ \\
\hline Geology: & $\begin{array}{l}\text { Mineralization in Cretaceous volcanics; } \\
\text { moderate to heavy veining with light pyrite } \\
\text { mineralization and } 1-2 \mathrm{~mm} \text { sericite envelopes. }\end{array}$ \\
\hline Production: & None. \\
\hline References: & $\begin{array}{l}\text { USGS, 1976, CRIB Mineral Resources File 12, } \\
\text { Record 1029, p. 2686-2687. }\end{array}$ \\
\hline
\end{tabular}

35. Unnamed Prospect VHNE $-025 \mathrm{~N}$

Location:

Commodity:

Ore Materials:

Deposit Description:

Geology:

Production:

References:
$32{ }^{\circ} 25^{-49} \mathrm{~N}, 111034-55^{\prime \mathrm{W}}$

Sec. 31, T11S, R8E

$\mathrm{Cu}$

Chrysocolla, malachite.

Small, trending N15\%, dipping steeply E

and $W$, disseminated, surface and underground workings.

Nineralization in Cretaceous welded tuff

(Mount Lord volcanics); series of closely spaced quartz-sulfide veinlets to $5 \mathrm{~cm}$ with now all oxidized and leached. Chrysocolla and malachite make it showy.

Undetermined.

USGS, 1976, CRIB Mineral Resources File 12, Record 1030, p. 2688-2690.

36. Unnamed Prospect VHNE-117N

Location:

$322^{\circ} 5^{-56} \mathrm{~N}, 111^{\circ} 34^{-1} 18^{\prime \prime} \mathrm{W}$

Sec. 31, T11S, R8E

Commodity:

$\mathrm{Cu}$

Ore Materials:

Chrysocolla-tenorite (chalcocite boxwork).

Deposit Description:

Small, disseminated-fracture type deposit, surface workings.

Geology:

Mineralization in Cretaceous volcanics,

Production:

Tertiary basalt dike.

References:

None.

USGS, 1976, CRIB Mineral Resources File 12, Record 1031, p. 2690-2671.

38. Unnamed Prospect VHNE-109N

Location:

Commodity:

Ore Materials:

Deposit Description:

Geology:

Production:

References: $322^{\circ} 5^{-2} 22^{\prime \prime} \mathrm{N}, 111^{\circ} 33^{\prime \prime} 13^{\prime \prime} \mathrm{W}$

Sec. 32, T11S, R8E

$\mathrm{Cu}$

Chrysocolla (chalcocite boxwork, probably chalcopyrite boxwork.)

Small, disseminated-fracture type deposit. Mineralization in Laramide quartz monzonite. None.

USCS, 1976, CRIB Mineral Resources File 12, Record 1033, p. 2695-2696. 
39. Unnamed Prospect VHiv-113iv

Location: $\quad 32025-39 " \mathrm{~N}, 111^{\circ} 32-57 " \mathrm{~W}$

Commodity:

Sec. 32, TIlS, R8E

Chalcocite-chrysocolla.

Deposit Description: Small, disseminated-fracture type, surface and underground workings.

Geology:

Production:

Mineralization in Laramide quartz monzonite.

None.

References: USGS, 1976, CRIB Mineral Resources File 12, Record 1034, p. 2697-2698.

40. Unnamed Prospect VHNE-078N

Location:

$322^{\circ} 6^{-9} 9^{\prime N}, 111^{\circ} 32^{-4} 46^{\prime \prime} \mathrm{W}$

Commodities:

Sec. 32, T11S, R8E

Ore Materials:

$\mathrm{Cu}, \mathrm{Mo}$

Deposit Description:

Malachite (chalcopyrite boxwork), molybdenite.

Geology:

Small, disseminated-fracture/veins/gossan

type, surface and underground workings.

Mineralization in Cretaceous-Tertiary granodiorite porphyry; very altered intrusive, moderate amount of sulfides with $k$-feldspar halos on veins, malachite stains observed and good chalcopyrite boxwork accounts for at least $1 / 2$ of sulfide gossan.

Production: None.

References: USGS, 1976, CRIB Mineral Resources File 12, Record 1035, p. 2699-2700.

41. Unnamed Prospect VHNE-079N

Location:

$32025-59 " \mathrm{~N}, 111032-38 " \mathrm{~W}$

Sec. 32, T11S, R8E

Comnodity:

$\mathrm{Cu}$

Ore Material:

Chalcopyrite

Deposit Description:

Geology:

Small, disseminated-fracture type, surface workings.

Mineralization in Laramide quartz latite porphyry.

Production:

None.

References:

USGS, 1976, CRIB Mineral Resources File 12, Record 1036, p. 2701-2702.

42. Unnamed Prospect VHNE-160N

Location:

$32025-24 " \mathrm{~N}, 111032-32 \mathrm{WW}$

Sec. 33, TIIS, R8E

Commodity:

$\mathrm{Cu}$

Ore Materials:

Malchite.

Deposit Description:

Small, disseminated-fracture type, underground workings.

Geology:

Mineralization in Laramide quartz latite

Production:

porphyry.

References:

None.

USGS, 1976, CRIB Mineral Resources File 12, Record 1037, p. 2703-2704, Stipp et. al., 1967. 
43. Unnamed Prospect VHNE-156N

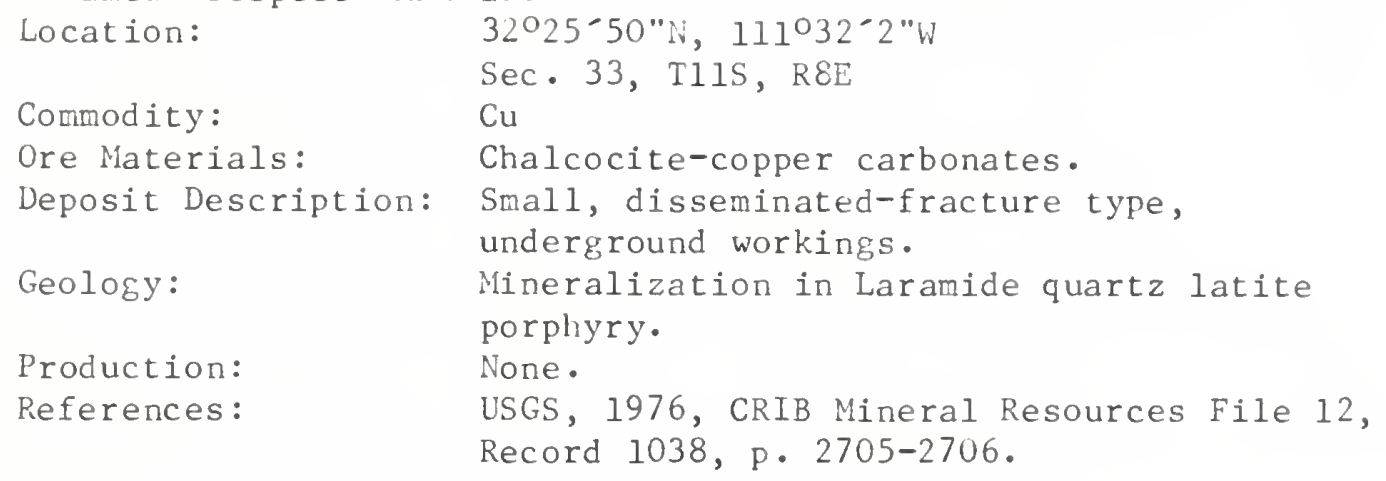

45. Unnamed Prospect VHNE-154N

Location: $\quad 320^{\circ} 26^{-9} \mathrm{~N} \mathrm{~N}, 111^{032-9 " \mathrm{~W}}$

Sec. 33, TllS, R8E

Commodity: $\quad \mathrm{Cu}$

Ore Materials: Chalcocite, turquoise.

Deposit Description: Small, disseminated-fracture type.

Geology: Mineralization in Laramide quartz latite porphyry.

Production: Yes, small amount.

References: $\quad$ USGS, 1976, CRIB Mineral Resources File 12, Record 1040, p. 2709-2710.

46. Unnamed Prospect VHNE-153N

Location:

$32{ }^{\circ} 26^{-8 * \mathrm{~N},} 111^{\circ} 31^{-55 " \mathrm{~W}}$

Sec. 33, Tlls, R8E

Commodities:

$\mathrm{Cu}, \mathrm{Mo}$

Ore Materials:

Chalcopyrite, molybdenite and chalcocite.

Deposit Description: Small, disseminated-fracture type, drill hole.

Geology:

Mineralization in Laramide quartz latite porphyry.

Production:

None.

References: USGS, 1976, CRIB Mineral Resources File 12, Record 1041, p. 2711-2712.

47. Unnamed Prospect VHNE-152:
Location:
$32026-9 " \mathrm{~N}, 111^{\circ} 31^{-47} \mathrm{WW}$
Commodity:
Sec. 32, TIIS, R8E
Ore Materials:
$\mathrm{Cu}$
Chalcopyrite, chalcocite. 
Deposit Description: Small, disseminated-fracture type, surface workings.

Geology: Mineralization in Laramide quartz latite porphyry.

Production: None.

References: USGS, 1976, CKIB Mineral Resources File 12, Record 1042, p. 2713-2714.

48. Unnamed Prospect VHNE-159N

Location:

$32025^{-3} 35^{\prime \prime N}, 111031^{-53 * \mathrm{~W}}$

Sec. 33, T11S, R8E

Commodity:

$\mathrm{Cu}$

Ore Materials:

Chalcocite, turquoise.

Deposit Description:

Small, disseminated-fracture type,

underground workings.

Geology:

Mineralization in Laramide quartz latite.

Production:

None.

References:

USGS, 1976, CRIB Mineral Resources File 12, Record 1043, p. 2715-2716.

49. Unnamed Prospect VHINE-158N

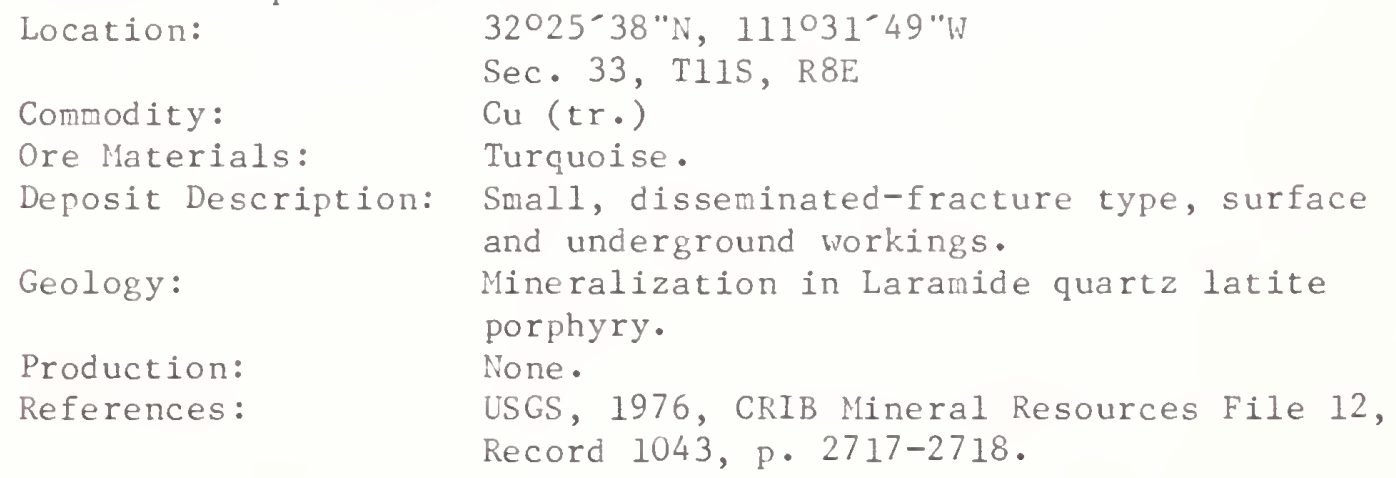

50. Unnamed Prospect VHNE-135N

Location:

Commodity:

Ore llaterials:

Deposit Description:

Geology:

Production:

References:
$32025-52 \mathrm{~N}, 111030^{-56} \mathrm{w} \mathrm{W}$

Sec. 34, T11S, R8E

$\mathrm{Ba}, \mathrm{pb}$

Barite, galena, angelsite, cerussite.

Srall, trending $N 15^{\circ}-20^{\circ} \mathrm{E}$, dipping

$80 \%$, tabular form in a vein type deposit, surface and underground workings. Mineralization in Tertiary-Cretaceous quartz latite porphyry.

None.

USGS, 1976, CRIB Mineral Resources File 12, Record 1045, p. 2719-2720.

51. Unnamed Prospect VHNE-151N

Location:

Comriodity:

Ore Materials:

Deposit Description:

Geology:
$32025^{-} 21^{\prime \prime} \mathrm{N}, 111^{\circ 030^{-}} 26^{\prime \mathrm{W}}$

Sec. 35, TIIS, R8E

$\mathrm{Cu}$

Chalcocite boxwork.

Small, disseminated-fracture type, underground workings.

Mineralization in Cretaceous Mount Lord volcanics. 
$\begin{array}{ll}\text { Production: } & \text { None. } \\ \text { References: } & \text { USGS, 1976, CRIB Mineral Resources File 12, } \\ & \text { Record 1046, p. 2721-2722, Stipp et. al., } \\ & 1967 .\end{array}$

52. Unnamed Prospect VHNE-041N
Location: $\quad 320^{\circ} 19^{-} 55^{\prime \prime} \mathrm{N}, 111^{\circ} 30^{\circ} 19^{\prime \prime} \mathrm{W}$
Sec. 35, T12S, R8E

Comnodity: $\quad \mathrm{Cu}$

Ore Materials: Malachite.

Deposit Description: Small, vein-disseminated type deposit. Geology: Mineralization in Permian Concha (?) or

Scherrer Fm. (?) (limestone) or other Paleozoic formation.

Production: None.

References: $\quad$ USGS, 1976, CRIB Mineral Resources File 12, Record 1063, p. 2766-2767, Stipp et. al., 1967.

54. Unnamed Prospect VHNE-042N

Location: $\quad 32^{\circ} 19^{-} 55^{\mathrm{N}} \mathrm{N}, 111030^{-7} \mathrm{~m} \mathrm{~W}$

Sec. 3, T12S, R8E

Commodity: $\quad \mathrm{Cu}$

Ore Material: Malachite.

Deposit Description: Small, trending $155^{\circ} \mathrm{W}$, dipping $55^{\circ} \mathrm{S}$,

Geology: Mineralization in Concha (?) fm. (limestone); abundant malachite along fault zone, associated quart $z$ veins and oxidized sulfide.

Production: None.

References: $\quad$ USGS, 1976, CRIB Mineral Resources File 12, Record 1065, p. 2770-2771, Stipp et. al., 1967.

57. Unnamed Prospect VHNE-083N

$\begin{array}{ll}\text { Location: } & 32024-44 " \mathrm{~N}, 111^{0} 33^{\circ} 19^{\prime \prime} \mathrm{W} \\ & \text { Sec. } 5, \mathrm{~T} 12 \mathrm{~S}, \mathrm{R} 8 \mathrm{E}\end{array}$

Commodity: $\mathrm{Cu}$

Ore Materials: Malachite, chrysocolla, neotocite.

Deposit Description: Small, disseminated-fracture type, surface and underground workings.

Geology:

Mineralization in Cretaceous-Tertiary quartz monzonite or alaskite; abundant copper oxides in trenches, moderate pyrite veining and gossan in footwall block showing some chalcocite boxwork. Tertiary gravel in hanging wall shows some exotic copper oxide and this copper was apparently the target of mining.

Production: None.

References:

USGS, 1976, CRIB Mineral Resources File 12, Record 1068, p. 2777-2778, Stipp et. al., 1967. 
58. Unnamed Prospect VHNE-094N

Location:

Commodity:

Ore Materials:

Deposit Description:

Geology:

Production:

References:
$32{ }^{\circ} 24^{-2}-27 " \mathrm{~N}, 111^{\circ} 33^{-2} 23^{\prime \prime W}$

Sec. 5, T12S, R8E

$\mathrm{Cu}$

Chrysocolla.

Sriall, surface workings.

Mineralization in Cretaceous sediments

(Claflin Ranch Fm. ?)

None.

USGS, 1976, CRIB Mineral Resources File 12, kecord 1069, p. 2779-2780.

59. Unnamed Prospect VHNE-086N

Location:

$322^{\circ} 342 " \mathrm{~N}, 111032^{-14} \mathrm{w} \mathrm{W}$

Sec. 9, T12S, R8E

Commodity:

$\mathrm{Cu}$

Ore Materials:

Chrysocolla.

Deposit Description:

Geology:

Production:

Snall, exotic type, underground workings.

Mineralization in Cretaceous sediments.

None.

References:

USGS, 1976, CRIB Mineral Resources File 12, Record 1070, p. 2781-2782, Stipp et. al., 1967.

60. Unnamed Prospect VHINE-83N

Location:

$32023-30 \mathrm{w}, 111^{\circ} 31^{-42} \mathrm{w} \mathrm{W}$

Sec. 9, T12S, R8E

Commodity:

$\mathrm{Cu}$

Ore Materials:

Malachite chalcocite boxwork.

Deposit Description:

Small, disseminated-fracture type, surface workings.

Geology:

Mineralization in Cretaceous red beds.

Production:

iNone.

References:

USGS, 1976, CRIB Mineral Resources File 12, Record 1071, p. 2783-2784.

61. Unnamed Prospect VHNE-085N

Location:

Conmodity:

Ore Materials:

Deposit Description:

Geology:

Production:

References:
$32023-45 " \mathrm{~N}, 111032-22 \% \mathrm{~W}$

Sec. 9, TI2S, R8E

$\mathrm{Cu}$

Malachite, chrysocolla.

Small, disseminated-fracture type, surface workings.

Mineralization in Cretaceous sediments.

None.

USGS, 1976, CRIB Mineral Resources File 12, Record 1072, p. 2785-2786.

62. Unnamed Prospect VHNE-008R

Location:

Commodity:

Ore Materials:

Deposit Description:
$32023-32 " \mathrm{~N}, 111031-37 " \mathrm{~W}$

Sec. 9, T12S, R8E

$\mathrm{Cu}$

Copper oxide-chrysocolla, malachite.

Small, trending N530\%, dipping steeply, variable; disseminated-fracture type. 
Geology:

Production:

Mineralization in Cretaceous sedinents.

References:

None.

USGS, 1976, CRIB Mineral Resources File 12, Record 1073, p. 2787-2788.

63. Unnamed Prospect VHNE-082N

Location:

$32023^{-} 23^{\prime \prime} \mathrm{N}, 111^{\circ} 31^{-9} \mathrm{~g}^{\mathrm{W}}$

Commodity:

Sec. 10, T12S, R8E

Ore Materials: Malachite (chalcocite gossan).

Deposit Description: Small, disseminated-fracture type.

Geology:

Mineralization in hornsfelsed Cretaceous

Production:

red beds.

References:

None.

USGS, 1976, CRIB Mineral Resources File 12, Record 1074, p. 2789-2790.

64. Unnamed Prospect VHNE-080N

Location:

$322^{\circ} 249 " \mathrm{~N}, 111^{\circ} 31^{\prime \prime} 1^{\prime \prime} \mathrm{W}$

Sec. 15, T12S, R8E

Commodity:

$\mathrm{Cu}$

Ore Materials: Malachite, chrysocolla.

Deposit Description: Small, disseminated-fracture type.

Geology:

Production:

References:

Mineralization in Cretaceous red beds.

None.

USGS, 1976, CRIB Mineral Resources File 12, Record 1075, p. 2791-2792, Stipp et. al., 1967.

65. Unnaned Prospect VHNE-009R

Location:

$32022-38 " \mathrm{~N}, 111030-37 \mathrm{~W}$

Sec. 15, T12S, R8E

Commodity:

$\mathrm{Cu}$

Ore Materials: Chrysocolla, malachite, boxwork chalcopyritechalcocite-pyrite.

Deposit Description: Small, trending N600E, dipping steep S. disseminated-fracture type, underground workings.

Geology:

Mineralization in Cretaceous sediments associ-

Production: ated with Tertiary quartz latite dike. None.

References:

USGS, 1976, CRIB Mineral Resources File 12, Record 1076, p. 2793-2794.

66. Unnamed Prospect VHNE-026N

Location:

Commodity:

Ore Materials:

Deposit Description:

Geology :

Production:

References:
$32{ }^{\circ} 12-37 \cdots \mathrm{N}, \quad 111^{\circ} 33-55^{\circ \mathrm{W}}$

Sec. 19, T12S, R8E

$\mathrm{Cu}$

Trace of copper carbonate.

Small, variable trending, disseminated type deposit.

Mineralization in Cretaceous andesite associated with quartz-epidote veining.

None.

USGS, 1976, CRIB Mineral Resources File 12, Record 1077, p. 2795-2796. 
67. Unnaned Prospect VHive-O30N

Location: $\quad 320^{\circ} 22^{-46} " \mathrm{~N}, 111^{\circ} 30-35 \% \mathrm{~W}$

Sec. 22, 23, T12S, R8E

Commodity: $\quad \mathrm{Cu}$

Ore Materials: Chalcocite, covellite, malachite, chrysocolla. Deposit Description: Small, fissure-vein type.

Geology:

Mineralization in Cretaceous sediments associated with quartz gangue.

Production: None.

References: USGS, 1976, CRIB Mineral Resources File 12, Record 1078, p. 2797-2798, Stipp et. al., 1967.

69. Unnamed Prospect VHNE-047N

Location:

Commodity:

Ore Materials:

Deposit Description: Geology:

Production:

References:
$32020^{-} 48 " \mathrm{~N}, 111030^{\circ} 10^{\prime \prime} \mathrm{W}$

Sec. 26, T12S, R8E

$\mathrm{Cu}$

Chalcocite.

Small, EW trending vein type.

Mineralization in Precambrian Oracle Granite. None.

USGS, 1976, CRIB Mineral Resources File 12, Record 1080, p. 2801-2802.

70. Unnamed Prospect VHne-043N

Location:

$320^{\circ} 0^{-3} \mathrm{NN}, 111030^{-6} \mathrm{NW}^{\mathrm{W}}$

Sec. 35, T12S, R8E

Commodities:

$\mathrm{Cu}, \mathrm{Pb}$ (potential); V, Ba, Ag (occurrence)

Ore Materials: Azurite, galena, cerrusite, anglesite, vanadinite, barite.

Deposit Description:

Geology:

Small, contact metanorphic type, several

prospects.

Mineralization in Permian Sherrer Fm. + Precambrian Oracle Granite.

Production:

None.

References:

USGS, 1976, CRIB Mineral Resources File 12, Record 1081, p. 2803-2804.

76. Unnamed Prospect 145-2

Location:

Commodity:

Ore Materials:

Deposit Description: Geology:

Production:

References: $32021^{\prime} 7 " \mathrm{~N}, 111^{\circ} 11^{-60} \mathrm{~m} \mathrm{~W}$

Sec. 34, T12S, R11E

$\mathrm{Cu}$

Cu silicate.

Small, shear zone type, surface workings. Mineralization in Precambrian Pinal Schist and in Paleozoic limestone associated with Cretaceous quartz monzonite; prospect at contact between gray-brown limestone to west and brecciated Pinal Schist; scarce Cu silicate on fractures.

None.

USGS, 1976, CRIB Mineral Resources File 12, Record 1326, p. 3499-3500. 
77. Unnamed Prospect 145-1

Location:
Commodity:
Ore Materials:
Deposit Description:

Geology:

Production:

References:
$32021^{-5} 5^{\prime N}, 111^{\circ} 11^{-56} 56^{\prime W}$

Sec. 34, T12S, R11E

$\mathrm{Cu}$

$\mathrm{Cu}$ silicate.

Snall, trending $144{ }^{\circ} \mathrm{W}$, dipping $87{ }^{\circ} \mathrm{W}$, veinlets in a mesothermal/shear zone, surface workings.

Mineralization in Precambrian Pinal Schist and in Cretaceous quartz monzonite.

None.

USGS, 1976, CRIB Mineral Resources File 12, Record 1327, p. 3501-3503.

78. Unnamed Sand and Gravel Occurrence

Location:

Commodities:

Sec. 34, T8S, R9E

Production:

Sand and gravel

Reference:

Unknown.

McCrory \& H'Haire, 1965.

79. Unnamed Fluorspar Occurrence
Location:
Conmodity:
Production:
Sec. 18, T12S, R8E
Fluorospar
Unknown.
References:
McCrory \& O־Haire, 1965.

80. Unnamed Limestone Occurrence
Location:
Commodity:
Sec. 26, T12S, RIIE
Production:
Limestone
References:
Unknown.
McCrory \& O־Haire, 1965.

82. Unnamed Tungsten Occurrence
Location:
Commodity:
Sec. 10, T7S, RI1E
Production:
Tungsten.
References:
Unknown.
Stipp, Haigler, Alto and Sutherland, 1967.

83. Unnamed Silver, Copper and Gold Occurrence

Location:

Commodities:

Production:

References:

Sec. 14, T9S, R9E

$\mathrm{Ag}, \mathrm{Cu}, \mathrm{Au}$

Unknown.

Stipp, Haigler, Alto and Sutherland, 1967.

84. Unnamed Silver, Copper and Gold Occurrence

Location: Sec. 28, T9S, R9E

Commodities: $\quad \mathrm{Ag}, \mathrm{Cu}, \mathrm{Au}$

Production: Unknown.

References: Stipp, Haigler, Alto and Sutherland, 1967.

85. Unnamed Mineral Occurrence
Location:
Commodity:
Sec. 31, T9S, R11E
Unknown
Production:
Unknown.
References:
Stipp, Haigler, Alto and Sutherland, 1967.

86. Unnamed Manganese Occurrence

Location:

Commodity:
Sec. 33, T11S, R7E

$\mathrm{Mn}$ 
Production: Unknown.

References: Stipp, Haigler, Alto and Sutherland, 1967.

87. Unnamed Limestone Occurrence
Location:
Comnodity:
Sec. 26, T12S, RIIE
Production:
Limestone
References:
Unknown.
Stipp, Haigler, Alto and Sutherland, 1967.

88. Unnamed Copper Occurrence

$\begin{array}{ll}\text { Location: } & \mathrm{Sec} .31, \mathrm{~T} 6 \mathrm{~S}, \mathrm{R} 1 \mathrm{OE} \\ \text { Commodity: } & \mathrm{Cu} \\ \text { Production: } & \text { Unknown. } \\ \text { References: } & \text { Johnson, 1981. }\end{array}$

89. Unnamed Copper Occurrence

Location: $\quad$ Sec. 32, T6S, RIOE

Commodity: $\mathrm{Cu}$

Production: Unknown.

References: Johnson, 1981, Yeend, 1976.

90. Unnamed Copper Occurrence

Location: Sec. $32 \mathrm{~T} 6 \mathrm{~S}, \mathrm{RIOE}$

Commodity: $\mathrm{Cu}$

Production: Unknown.

References: Johnson, 1981.

91. Unnamed Copper Occurrence

Location: Sec. 1, T7S, RYE

Commodity: $\mathrm{Cu}$

Production: Unknown.

References: Johnson, 1981.

92. Unnamed Copper Occurrence

Location: Sec. 6, T7S, RIOE

Commodity: $\quad \mathrm{Cu}_{\mathrm{u}}$

Production: Unknown.

References: Johnson, 1981.

93. Unnamed Copper Occurrence

$\begin{array}{ll}\text { Location: } & \mathrm{Sec} .6, \mathrm{~T} 7 \mathrm{~S}, \mathrm{R} \text { IOE } \\ \text { Commodity: } & \mathrm{Cu} \\ \text { Production: } & \text { Unknown. } \\ \text { References: } & \text { Johnson, 1981. }\end{array}$

94. Unnamed Copper Occurrence

Location: Sec. 6, T7S, RlOE

Commodity: $\quad \mathrm{Cu}$

Production: Unknown.

References: Johnson, 1981.

95. Unnamed Copper Occurrence

Location:

Commodity:

Sec. 6, T7S, R1OE

Production:

$\mathrm{Cu}$

References: Johnson, 1981. 
96. Unnawed Copper Occurrence

Location: Sec. 5, T7S, R10E

Commodity: $\mathrm{Cu}$

Production: Unknown.

References: Johnson, 1981.

97. Unnamed Copper Occurrence

Location: $\quad \mathrm{Sec} \cdot 4, \mathrm{~T} 7 \mathrm{~S}, \mathrm{R} 10 \mathrm{E}$

Commodity: $\mathrm{Cu}$

Production: Unknown.

References: Johnson, 1981, Yeend, 1976.

98. Unnamed Copper Occurrence

Location: $\quad \mathrm{Sec} \cdot 3, \mathrm{~T} 7 \mathrm{~S}, \mathrm{R} 10 \mathrm{E}$

Commodity: $\mathrm{Cu}$

Production: Unknown.

References: Johnson, 1981, Yeend, 1976.

99. Unnamed Copper Occurrence

Location: $\quad \mathrm{Sec} \cdot$ 9, T7S, RIOE

Comnodity: $\mathrm{Cu}$

Production: Unknown.

References: Johnson, 1981.

100. Unnaned Copper Occurrence

Location: $\quad \mathrm{Sec} \cdot 7, \mathrm{~T} 7 \mathrm{~S}, \mathrm{R} 10 \mathrm{E}$

Comodity: $\mathrm{Cu}$

Production: Unknown.

References: Johnson, 1981.

101. Unnamed Copper Occurrence

Location: $\quad \mathrm{Sec} \cdot 7$, T7S, RIOE

Comodity: $\mathrm{Cu}$

Production: Unknown.

References: Johnson, 1981.

102. Unnamed Copper Occurrence

Location: $\quad \mathrm{Sec} \cdot 7, \mathrm{~T} 7 \mathrm{~S}, \mathrm{RIOE}$

Commodity: $\quad \mathrm{Cu}$

Production: Unknown.

References: Johnson, 1981.

103. Unnamed Copper Occurrence

Location: Sec. 7, I7S, RIOE

Commodity: $\mathrm{Cu}$

Production: Unknown.

References: Johnson, 1981.

104. Unnaned Copper Occurrence
Location:
Commodity:
Production:
Sec. 7, T7S, R1OE
$\mathrm{Cu}$
Unknown.
References: Johnson, 1981, Yeend, 1976. 
105. Unnamed Copper Mine

Location:

Comelodity:

Sec. 7, T7S, RIOE

Production:

$\mathrm{Cu}$

References: Johnson, 1981, Yeend, 1976.

106. Unnamed Copper Occurrence

Location: $\quad$ Sec. 18, T7S, RIOE

Commodity: $\mathrm{Cu}$

Production: Unknown.

References: Johnson, 1981, Yeend, 1976.

107. Unnamed Copper Occurrence

Location: Sec. 13, T7S, R9E

Commodity: $\mathrm{Cu}$

Production: Unknown.

References: Johnson, 1981.

108. Unnamed Copper Occurrence

Location: Sec. 24, T7S, R9E

Commodity: $\mathrm{Cu}$

Production: Unknown.

References: Johnson, 1981.

109. Unnamed Copper Occurrence

Location: Sec. 33, T7S, R9E

Commodity: $\quad \mathrm{Cu}$

Production: Unknown.

References: Johnson, 1981, Yeend, 1976.

110. Unnamed Copper Occurrence

Location: $\quad$ Sec. 33, T7S, R9E

Commodity: $\mathrm{Cu}$

Production: Unknown.

References: Johnson, 1981.

111. Unnamed Copper Occurrence

Location: Sec. 33, T7S, R9E

Commodity: $\mathrm{Cu}$

Production: Unknown.

References: Johnson, 1981.

112. Unnamed Copper Occurrence

Location: $\quad$ Sec. 34, T7S, R9E

Commodity: $\quad \mathrm{Cu}$

Production: Unknown.

References: Johnson, 1981.

113. Unnamed Copper Occurrence

Location: Sec. 34, T7S, R9E

Commodity: $\quad \mathrm{Cu}$

Production: Unknown.

References: Johnson, 1981. 
114. Unnamed Copper Occurrence

Location: $\quad \mathrm{Sec} \cdot 36, \mathrm{~T} 7 \mathrm{~S}, \mathrm{R} 9 \mathrm{E}$

Comnodity: $\quad \mathrm{Cu}$

Production: Unknown.

Reference: Johnson, 1981.

115. Unnamed Copper Occurrence

Location: Sec. 36, T7S, R9E

Commodity: $\quad \mathrm{Cu}$

Production: Unknown.

References: Johnson, 1981, Yeend, 1976.

116. Unnamed Copper Occurrence

Location: Sec. 36, T7S, R9E

Commodity: $\quad \mathrm{Cu}$

Production: Unknown.

Reference: Johnson, 1981.

117. Unnamed Copper Occurrence

Location: $\mathrm{Sec} \cdot 36, \mathrm{~T} 7 \mathrm{~S}, \mathrm{RgE}$

Commodity: $\quad \mathrm{Cu}$

Production: Unknown.

Reference: Johnson, 1981.

118. Unnamed Copper Prospect

Location: Sec. 33, T6S, RlOE

Commodity: $\mathrm{Cu}$

Production: Unknown.

Reference: Yeend, 1976.

119. Unnamed Copper Occurrence

Location: $\mathrm{Sec}$. 33, T6S, RIOE

Commodity: $\mathrm{Cu}$

Production: Unknown.

Reference: Yeend, 1976.

120. Unnamed Copper Prospect

Location: Sec. 4, T7S, RIOE

Commodity: $\mathrm{Cu}$

Production: Unknown.

Reference: Yeend, 1976.

121. Unnamed Copper Prospect

Location: Sec. 4, T7S, RIOE

Commodity: $\mathrm{Cu}$

Production: Unknown.

Reference: Yeend, 1976.

122. Unnamed Copper Prospect

Location:

Commodity:

Production:

Reference:
Sec. 4, T7S, RIOE

$\mathrm{Cu}$

Unknown.

Yeend, 1976 
123. Unnamed Copper Prospect

$\begin{array}{ll}\text { Location: } & \text { Sec. 4, T7S, RlOE } \\ \text { Commodity: } & \mathrm{Cu} \\ \text { Production: } & \text { Unknown. } \\ \text { Reference: } & \text { Yeend, 1976. }\end{array}$

124. Unnamed Copper Prospect

Location: $\quad \mathrm{Sec} .3$, T7S, RIOE

Commodity: $\mathrm{Cu}$

Production: Unknown.

Reference: Yeend, 1976.

125. Unnamed Copper Prospect

Location: Sec. 5, T7S, RlOE

Commodity: $\mathrm{Cu}$

Production: Unknown.

Reference: Yeend, 1976.

126. Unnamed Copper Prospect
Location:
Commodity:
Sec. 5, T7S, RIOE
Production:
$\mathrm{Cu}$
Reference:
Unknown.
Yeend, 1976.

127. Unnamed Copper Prospect
Location:
Commodity:
Sec. 5, 8, T7S, RIOE
Production:
$\mathrm{Cu}$
Unknown.
Reference: Yeend, 1976.

128. Unnamed Copper Prospect
Location:
Commodity:
Sec. 6, T7S, R1OE
Production:
$\mathrm{Cu}$
Unknown .
Reference:
Yeend, 1976.

129. Unnamed Copper Prospect

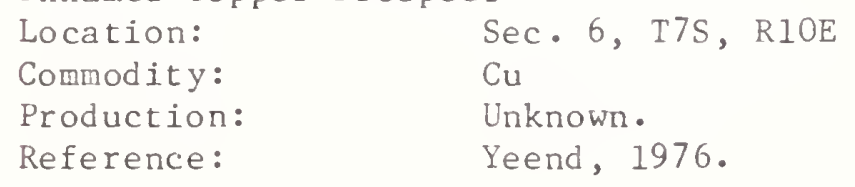

130. Unnamed Copper Prospect

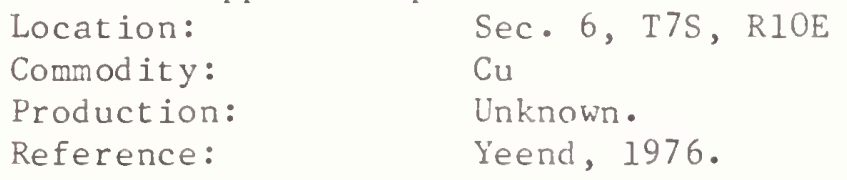

131. Unnawed Copper Prospect
Location:
Commodity:
Production:
Sec. 7, T7S, R10E
$\mathrm{Cu}$
Reference:
Unknown.
Yeend, 1976. 
132. Unnamed Copper Prospect

Location:

Commodity:

Production:

Reference:

133. Unnamed Copper Mine

Location:

Commodity:

Production:

Reference:

134. Unnamed Copper Mine

Location:

Commodity:

Production:

Reference:

135. Unnamed Copper Mine

Location:

Commodity:

Production:

Reference:

136. Unnamed Copper Mine

Location:

Commodity:

Production:

Reference:

137. Unnamed Copper Mine Location:

Commodity:

Production:

Reference:

138. Unnamed Copper Mine Location:

Commodity:

Production:

Reference:

139. Unnamed Copper Mine

Location:

Commodity:

Production:

Reference:
Sec. 8, T7S, RIOE

$\mathrm{Cu}$

Unknown •

Yeend, 1976.

Sec. 8, T7S, R1OE

$\mathrm{Cu}$

Unknown.

Yeend, 1976.

Sec. 8, T7S, R1OE

$\mathrm{Cu}$

Unknown •

Yeend, 1976.

Sec. 7, 8, T7S, RIOE

$\mathrm{Cu}$

Unknown •

Yeend, 1976.

Sec. 18, T7S, RIOE

$\mathrm{Cu}$

Unknown.

Yeend, 1976.

Sec. 19, T7S, R1OE

$\mathrm{Cu}$

Unknown •

Yeend, 1976.

Sec. 19, T7S, R1OE

$\mathrm{Cu}$

Unknown •

Yeend, 1976.

Sec. 19, T7S, R10E

$\mathrm{Cu}$

Unknown •

Yeend, 1976.

140. Unnamed Copper Occurrence

Location:

Commodity:

Production:

Reference:
Sec. 3, T8S, R9E

$\mathrm{Cu}$

Unknown •

Yeend, 1976. 
141. Unnamed Copper Prospect

Location: $\quad \mathrm{Sec} \cdot 4, \mathrm{~T} 8 \mathrm{~S}, \mathrm{R} 9 \mathrm{E}$

Commodity: $\mathrm{Cu}$

Production: Unknown.

Reference: Yeend, 1976.

142. Unnamed Copper Prospect

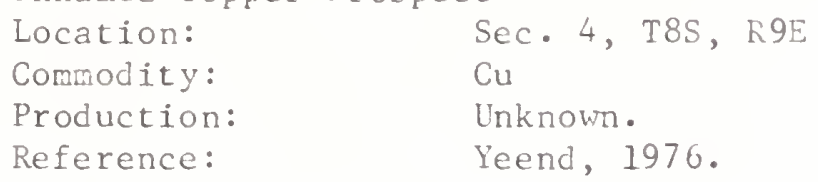

143. Unnamed Copper Prospect

Location: Sec. 13, T8S, R9E

Commodity: $\mathrm{Cu}$

Production: Unknown.

Reference: Yeend, 1976.

144. Unnamed Copper Prospect

Location: Sec. 13, T8S, R9E

Commodity: $\mathrm{Cu}$

Production: Unknown.

Reference: Yeend, 1976.

145. Unnamed Copper Occurrence

Location: $\quad$ Sec. 34, 8, T8S, R9E

Comilodity: $\mathrm{Cu}$

Production: Unknown.

Reference: Yeend, 1976.

146. Unnamed Copper Prospect

Location: Sec. 24, T8S, R9E

Commodity: $\mathrm{Cu}$

Production: Unknown.

Reference: Yeend, 1976.

147. Unnamed Copper Prospect

Location: Sec. 24, T8S, R9E

Commodity: $\mathrm{Cu}$

Production: Unknown.

Reference: Yeend, 1976.

148. Unnamed Copper Prospect

Location:

Comnodity:

Sec. 23, T8S, R9E

Production:

$\mathrm{Cu}$

Reference:

Unknown.

Yeend, 1976.

149. Unnamed Copper Mine

Location:

Commodity:

Sec. 24, T8S, R9E

Production:

$\mathrm{Cu}$

Reference:

Unknown.

Yeend, 1976. 
150. Unnamed Copper Occurrence

$\begin{array}{ll}\text { Location: } & \text { Sec. 23, T8S, R9E } \\ \text { Commodity: } & \mathrm{Cu} \\ \text { Production: } & \text { Unknown. } \\ \text { Reference: } & \text { Yeend, 1976. }\end{array}$

151. Unnamed Copper Prospect

$\begin{array}{ll}\text { Location: } & \text { Sec. 21, T8S, R9E } \\ \text { Commodity: } & \mathrm{Cu} \\ \text { Production: } & \text { Unknown. } \\ \text { Reference: } & \text { Yeend, 1976. }\end{array}$

152. Unnawed Gravel Pit
Location:
Comnodity:
Production:
Sec. 20, T8S, R9E
sg
Unknown.
Reference:
Yeend, 1976.

153. Unnamed Copper Occurrence
Location:
Commodity:
Production:
Sec. 28, T8S, R9E
$\mathrm{Cu}$
Reference:
Unknown •
Yeend, 1976.

155. Red Rock

Location:

Sec. 24, 8, T7S, RIIE

Location very approximate

Commodities:

$\mathrm{Ti}, \mathrm{Fe}$

Ore Material:

Titaniferous magnetite and ilmenite.

Deposit Description:

Placer.

Geology:

Alluvial deposits with disseminated and stratified magnetite deposits.

Production:

Unknown.

Reference:

Arizona Bureau Mines, Bul1. 180, 1969.

156. Unnamed Analcime Occurrence
Location:
Sec. 25, T7S, R8E
Commodity:
Analcime (zeolite)
Deposit Description:
Discovered in drill hole.
Geology:
In silty claystone of late Tertiary age.
Reference:
Arizona Bureau of Mines (1969).

157. Thermal Well

Location:

Temperature:

NE1/4 NE1/4 NE1/4, Sec. 36, T11S, R8E

Well Depth:

$32^{\circ} \mathrm{C}$.

235 meters.

Reference:

Witcher et. al., 1982. 
158. Area of Low Temperature Geothermal Waters Location:

$\mathrm{I} 6 \mathrm{~S}, \mathrm{R} 7,8$, and $9 \mathrm{E}$,

T7S, R7, 8, and $9 \mathrm{E}$,

T8S, R7, 8, and 9E,

T9S, R.7, and 8E,

T10S, R7, 8, 9, 10, 11E

T11S, R9, 10, 11 and $12 \mathrm{E}$

Geology:

Production:

T12S, R9, 10, 11 and 12E

References:

Deep Basin

None

Information from Witcher et. al., 1982, who state: "Existing knowledge does not in general permit the inference that thermal waters may be found everywhere within the depicted areas, nor do the boundaries represent current knowledge of the area's extent of the geothermal resources."

Note: Wells have reported temperatures of $32^{\circ} \mathrm{C}-110^{\circ} \mathrm{C}$ and well depth varies from $235 \mathrm{~m}$ to 3101 meters.

159. Exxon State (74) No. 1 Location:

Commodity: IW1/4 NW1/4, Sec. 2, T8S, R8E

Ore materials:

Oil and gas exploration well

Production: None - dry, abandoned.

Reference:

None. Total depth $=3,102 \mathrm{~m}(10,177 \mathrm{ft}$.

Eberly and Stanley, 1978.

160. Berry No. 1 Federal

Location:

Commodity:

NE $1 / 4 \mathrm{SE} 1 / 4, \mathrm{Sec} .27, \mathrm{~T} 11 \mathrm{~S}, \mathrm{R} 10 \mathrm{E}$

Ore Materials:

Oil and gas exploration

None - dry, abandoned.

Production:

None. Total depth $=979 \mathrm{~m}$.

Reference:

Eberly and Stanley, 1978.

\section{Mining Claims, Leases and Material Sites}

Mining claim density (number of claims per square mile) of the two WSAs and their surrounding areas is summarized in table 2 and shown in figure 6. Additionally, an outline of all land currently either fully or partially leased for oil and gas is shown in figure 6 (area enclosed by hachured lines). Much of the federal and fee land is leased for oil and gas for five or ten year terms. All data were obtained from the BLM's records of June, 1982. Eight unpatented claims are located within the Ragged Top WSA (020-197). Numerous patented claims, some associated with ASARCO's Silver Bell mine, are located within a few miles of the WSA. The entire WSA is leased for oil and gas. 
TABLE 2

CLAIM DENSITY RECORDS IN THE WILDERNESS STUDY AREAS (WSA), WYMOLA GRA ACCORDING TO BLM (JUNE 1982), ARIZONA STATE OFFICE

\begin{tabular}{|c|c|c|c|c|c|c|}
\hline Township & Range & Section & $\begin{array}{l}\text { Claims For } \\
\text { Each Section }\end{array}$ & Claimants & $\begin{array}{c}\text { Latest } \\
\text { Assmt. } \\
\text { Date }\end{array}$ & Remarks \\
\hline \multirow{3}{*}{$8 S$} & \multirow{3}{*}{$9 \mathrm{E}$} & & WSA 020-194 & cho Mountains & & \multirow{3}{*}{$\begin{array}{c}\text { Tode } \\
\text { " }\end{array}$} \\
\hline & & 10 & SW 1 & Moyer, Ray & none & \\
\hline & & 27 & SE 1 & Blanton, Jimmie & 1981 & \\
\hline
\end{tabular}

WSA 020-197 Ragged Top

115

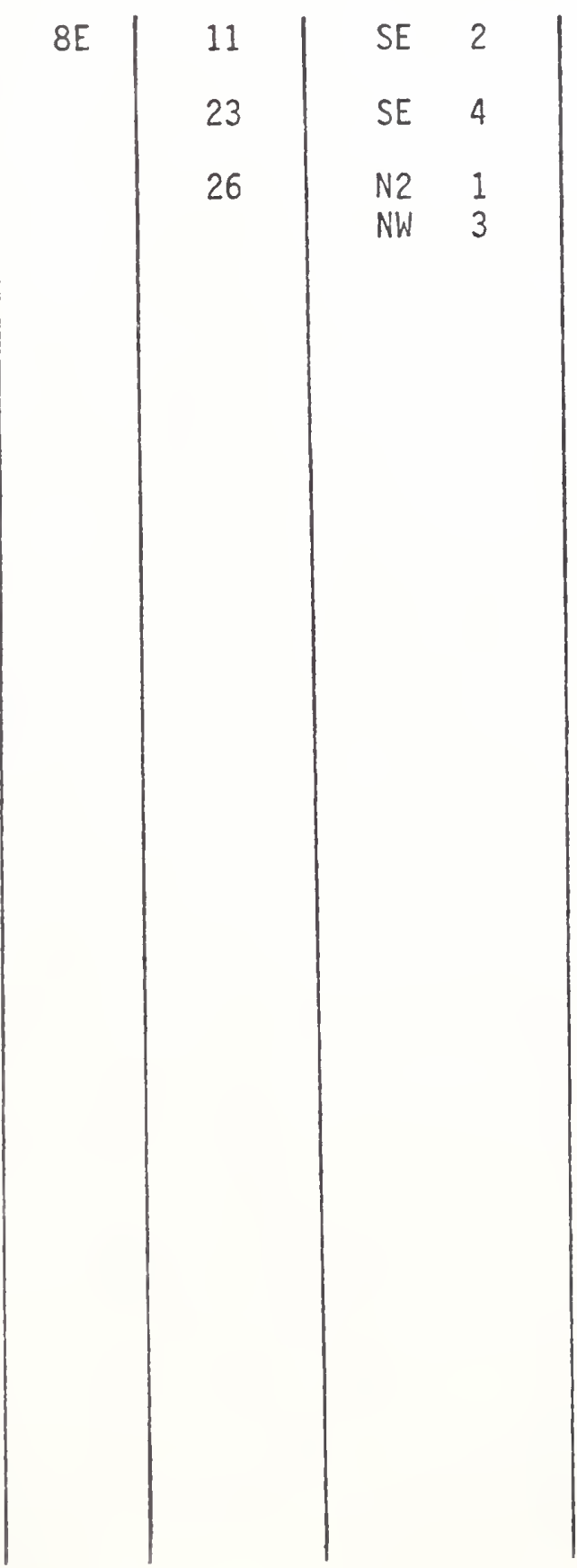


B.EE $111^{\circ} 30^{\circ} \quad$ R QE 
Two unpatented claims are located within the Picacho Mountains WSA (020-194), and the entire area is leased for oil and gas. No patented clains are located near the WSA. No information is available about commodities present in any claimed land in the Wymola GRA.

\section{Mineral Deposit Types}

Geological environments considered potentially favorable for the occurrence of mineral and energy resources include the following:

Older Precambrian igneous and metamorphic rocks,

Younger Precambrian rocks,

Paleozoic and Mesozoic sediments,

Laramide intrusive rocks,

Mid-Tertiary metamorphic core complexes,

Mid-Tertiary volcanic rocks,

Mid-Tertiary sediments,

Late Tertiary basin-fill sediments,

Recent alluvium, and

Active geothermal systems.

Table 3 lists these geological enviroments in relation to types of mineral deposits that may be expected.

Older Precambrian Igneous and Metamorphic Rocks

Ore deposit types that may have formed during the Precambrian include volcanogenic massive sulfide deposits and hydrothermal deposits associated with Precambrian intrusive activity or metamorphist.

Numerous occurrences of massive sulfide deposits are found in older Precambrian rocks in Arizona. They are invariably associated with submarine rhyolitic volcanism (Donnelly and Hahn, 1981), and are either of 
Table 3. GEOLOGICAL ENVIROMENTS OF THE WYMOLA AREA AND ASSOCIATED POTENTIAL MINERAL DEPOSIT TYPES

\begin{tabular}{|c|c|c|c|c|c|c|c|c|c|c|c|}
\hline $\begin{array}{l}\text { MINERAL } \\
\text { DEPOSIT } \\
\text { TYPE } \\
\text { GEOLOGICAL } \\
\text { ENVIROMENT - } \\
\text { HOST ROCKS }\end{array}$ & 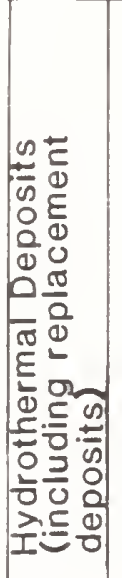 & 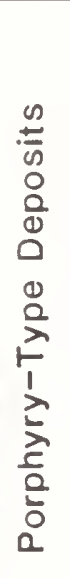 & 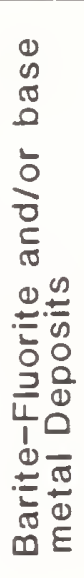 & $\begin{array}{l}0 \\
: 5 \\
0 \\
0 \\
0 \\
0 \\
0 \\
0 \\
0 \\
0 \\
2 \\
1 \\
0 \\
0 \\
0 \\
0 \\
0 \\
1 \\
0 \\
0 \\
0 \\
0\end{array}$ & 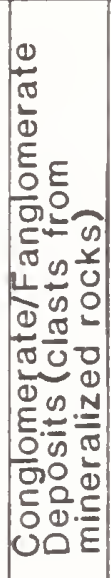 & $\begin{array}{l}0 \\
\frac{\pi}{n} \\
0 \\
0 \\
0 \\
0 \\
0 \\
0 \\
0 \\
\frac{\pi}{0}\end{array}$ & 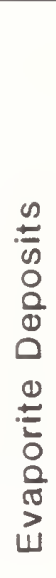 & 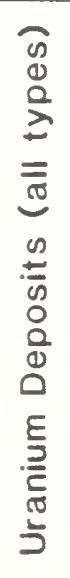 & 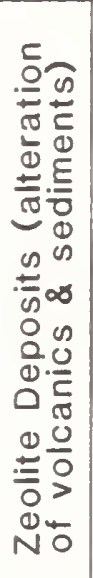 & 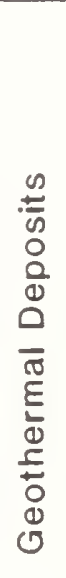 & 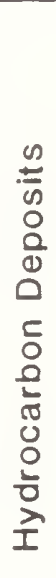 \\
\hline $\begin{array}{l}\text { Active Geothermal } \\
\text { Systems }\end{array}$ & & & & & & & & & & $\mathbf{X}$ & \\
\hline $\begin{array}{l}\text { Tertiary and Quaternary } \\
\text { Alluvium }\end{array}$ & & & & & & $\mathbf{X}$ & & & & & \\
\hline $\begin{array}{l}\text { Mid- and Late Tertiary } \\
\text { Basin-Fill Sediments }\end{array}$ & & & & & $\mathbf{X}$ & & $\mathbf{X}$ & $\mathbf{X}$ & $\mathbf{X}$ & $\mathbf{X}$ & \\
\hline $\begin{array}{l}\text { Mid-Tertiary Volcanic } \\
\text { Rocks }\end{array}$ & $\mathbf{X}$ & & $\mathbf{X}$ & & & & & $\mathbf{X}$ & & & \\
\hline $\begin{array}{l}\text { Mid-Tertiary Metamorphic } \\
\text { Core Complexes } \\
\text { (including upper plates) }\end{array}$ & $X$ & & & & & & & $\mathbf{X}$ & & & \\
\hline $\begin{array}{l}\text { Laramide Intrusive } \\
\text { Rocks }\end{array}$ & & $\mathbf{X}$ & & & & & & & & & \\
\hline $\begin{array}{l}\text { Paleozoic and Mesozoic } \\
\text { Sediments }\end{array}$ & & & & $\mathbf{X}$ & & & & & & & $\mathbf{X}$ \\
\hline $\begin{array}{l}\text { Younger Precambrian } \\
\text { Rocks }\end{array}$ & $X$ & & & & & & & $\mathbf{X}$ & & & \\
\hline $\begin{array}{l}\text { Older Precambrian } \\
\text { Igneous and } \\
\text { Metamporphic Rocks }\end{array}$ & $\mathbf{X}$ & & & & & & & & & & \\
\hline
\end{tabular}


the copper-rich proximal type or the zinc and lead-rich distal type (Anderson and Guilbert, 1979). They are commonly associated wth banded iron formations which are zoned, with sulfide facies near the rhyolitic center and carbonate and oxide facies further away (Anderson and Guilbert, 1979). Netavolcanic rocks occur in the Yavapai Series and in the gneissic terrain to the northwest and both lie to the northwest of the Holbrook line which separates them from the non-volcanogenic Pinal Schist (see fig. 2A). The GRA is located to the southeast of the Holbrook line and is probably largely underlain by metasedimentary Pinal Schist and Precambrian granitic intrusives. No massive sulfide occurrences are known in the Wymola GRA.

There are many occurrences of hydrothermal copper mineralization in Precambrian Pinal Schist and Oracle Granite of the northern Picacho Mountains (see fig. 3). At least some of these occurrences are related to the Tertiary North Star Stock (Johnson, 1981) but others may be related to granitic intrusion or a Precambrian metamorphic event. Hydrothermal copper mineralization also occurs in Precambrian granitic rocks of the West Silver bell Mountains ( $\mathrm{Cu}$ 1) and in the area just west of the Ragged Top WSA ( $\mathrm{Cu} 16$; $\mathrm{Pb} 17$, containing copper and zinc in addition to lead). These occurrences may also be related to Precambrian events or later hydrothermal events. Mineralization in Pinal Schist ( $\mathrm{Pb} 72$ ) of the Twin Peaks, southeastern part of the GRA is continuous into Paleozoic sediments and thus is doubtlessly post-Precambrian.

\section{Younger Precambrian Rocks}

Forty-six uranium deposits or occurrences have been identified in carbonand potassium-rich siltstones of the Dripping Spring Quartzite of the Precambrian Apache Group in Gila County, northeast of the Wymola GRA. The deposits occur in close proximity to younger Precambrian diabase intrusives 
and the diabases have been suggested as the source of the uranium concentrated in sediments of the Dripping Spring Quartzite (Granger and Raup, 1969). No uranium occurrences have been reported for the hymola GRA, but both Precambrian diabases and Apache Group sediments crop out in the southern part of the GRA and a possibility exists that undiscovered occurrences may be present within the GRA.

Two copper occurrences (16 and 24) are located in Precambrian diabase, one ( $\mathrm{Cu}$ 16) along the contact where the diabase intrudes older Precambrian granitic rocks. These occurrences may be related to the diabase or may have resulted from a later event.

Paleozoic and Mesozoic Sediments

Paleozoic and Mesozoic sediments are potential host rocks for accumulation of hydrocarbons and possibly red-bed type copper and silver deposits. In south Arizona, Paleozoic and Mesozoic sediments, especially in the possible extension of the Overthrust Belt, have been considered potentially favorable for the accumulation of hydrocarbons (Keith, 1980; Peirce, 1982). All exploration wells drilled to date however, have been dry (Peirce, 1979; Keith, 1981; Peirce, 1982; see fig. 7). In the Wymola GRA, eight such holes have been drilled in the deep basins of the area (fig. 7).

Paleozoic and Mesozoic sedimentary rocks crop out in the Twin Peaks, Waterman Mountains and Silver Bell Mountains in the southern part of the GRA. Potential source rocks for hydrocarbons are shales and fetid limestones in the Abrigo and Martin Formations. Mesozoic rocks are non-marine, are not known to be rich in organic matter and are unlikely to be good source rocks for hydrocarbons. Locally, they could be effective reservoir rocks.

Both the Paleozoic and Mesozoic sediments have undergone deformation during the Laramide and mid-Tertiary orogenies with Paleozoic sediments 


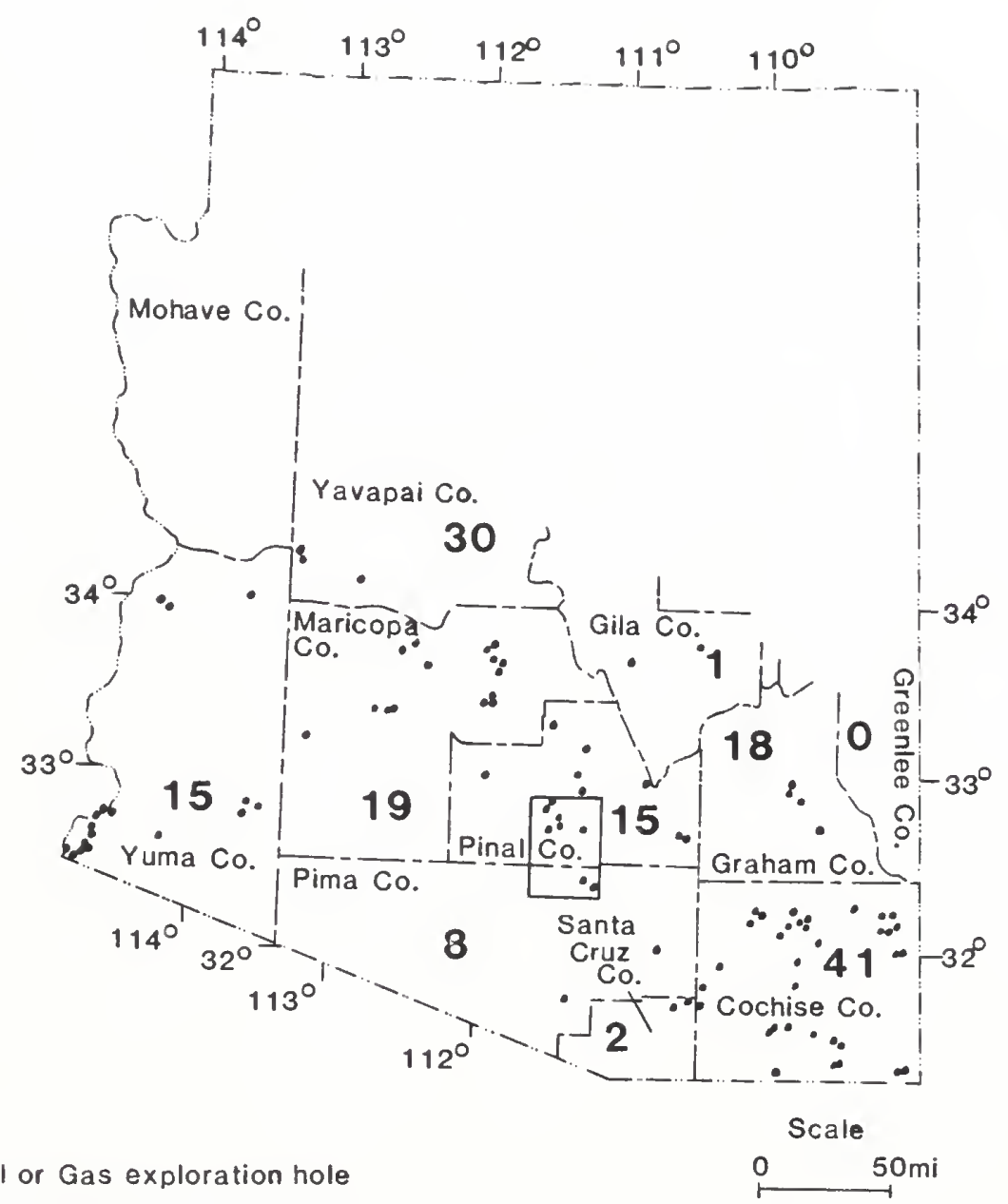

15 Number of holes in county

FIG.7 LOCATION OF OIL AND GAS EXPLORATION HOLES IN SOUTHERN ARIZONA, after Jones (1979). 
subjected to the mid-Mesozoic orogeny as well, and during Basin and Range faulting. They have been metamorphosed and are structurally highly complex. Thus, they are not considered favorable for the accumulation of hydrocarbons. It should be noted, however, that there has been recent drilling activity in southern Arizona based on a reinterpretation of seismic data which suggests that extensive thrust sheets are present in the area (Keith, 1980; Peirce, 1982). According to this interpretation rocks cropping out at the surface have been thrust over Paleozolc and Mesozoic sediments which are potentially favorable for the accumulation of hydrocarbons. We have no data to support or refute this except to note that one hole drilled near Florence (just north of the GRA) on the basis of such an interpretation bottomed in granite at 18,000 feet (Keith, 1981).

Thick Mesozoic red beds crop out in the Silver Bell Mountains within the Wymola GRA. Such beds are potentially favorable for red bed-type, copper silver deposits such as are present in Permian and Triassic sediments in central and northern New Mexico (LaPoint, 1974a, 1974b). No occurrences of this sort are known in the GRA, but the presence of permeable red-beds suggests that a favorable environnent for such deposits could be present.

\section{Laramide Intrusives}

The Laramide was a time of emplacement of all but one (Bisbee) of the porphyry copper deposits in Arizona and adjacent New Mexico and Mexico. Of the 35 major porphyry copper deposits in this region, 32 lie to the southeast of the Holbrook line where basement is the Pinal Schist and three lie to the northwest where basement consists of Yavapai Series and gneissic-metavolcanic terrain (see fig. 2C). The intrusives associated with the porphyry copper deposits were emplaced during the westward sweep of the magmatic arc (Damon et al., 1981; Clark et al., 1982), possibly related to the decrease in the 
dip of the Benioff zone at this time (Coney and Reynolds, 1977). The porphyry copper deposits appear to be aligned along northwest and east-northeast trends (Heidrick and Titley, 1982; see fig. 2). The northwesterly trend is subparallel to Mesozoic linear discontinuities in depositional patterns (Titley, 1976); the trend of Laramide basement-cored uplifts and thrust faults (Nielson, 1979; Davis, 1981); the Texas zone of Schmitt (1966); and the trend of the Laramide magmatic arcs. The ENE trend is sub-parallel to Precambrian fold axes and Laramide tensional features (Rehrig and Heidrick, 1976). The intrusions related to the porphyry copper deposits are small in area (seldom over $3 \mathrm{~km}^{2}$ ) and may have been emplaced along the NW and ENE structural intersection (Titley, 1981).

$\mathrm{ASARCO}^{-}$s important Silver Bell porphyry copper deposit is located a few miles south and southwest of the Ragged Top WSA in the southern part of the Wymola GRA. High-grade replacement deposits in Paleozoic limestones intruded by Laramide igneous rocks were the first source of ore in the Silver Bell Mountains (Richard and Courtright, 1966). Prior to 1930, replacement deposits of Mamroth Mine, Union Mine (both included as $\mathrm{Cu} 55$ ) and Atlas Mine produced about 100 million pounds of copper (Richard and Courtright, 1966). Production from disseminated deposits in Paleozoic sediments and Laramide porphyries mined in the Oxide ( $\mathrm{Cu}$ 75) and El Tiro ( $\mathrm{Cu}$ 74) of the Silver Bell Mine ( $\mathrm{Cu}$ 56) yielded $75,655,000$ tons of ore averaging $0.80 \% \mathrm{Cu}, 0.07$ ounces Ag per ton and $0.022 \% \operatorname{MoS}_{2}$ between 1954 and 1977 (Graybeal, 1982). Laramide mineralization is also hosted by Cretaceous andesites and sediments and possibly Precambrian rocks in addition to the Paleozoic sediments and Laramide intrusives. Most of the numerous occurrences and deposits of the southern GRA shown in figure 3 resulted from Laramide mineralization.

Laramide intrusives in the Silver Bell Mountains are elongated parallel to pre-Laramide discontinuities (see fig. 2C) and apparently were emplaced 
along a fault contact which separated Paleozoic and Mesozoic sediments (see fig. 3; Richard and Courtright, 1966; Graybeal, 1982). It is possible that other Laramide intrusives and, potentially, porphyry copper deposits exist in the GRA and remain unroofed.

Mid-Tertiary Metamorphic Core Complexes

The potential for mineral deposits associated with metamorphic core complexes is not well known as only during the last ten or so years have the complexes themselves been widely recognized. In an important work, Coney and Reynolds (1980) and several co-workers have attempted to assess uraniun favorability of these complexes and in so doing they have also provided useful information on some other elewents. Some important findings of this study wich also includes the report by Keith and Reynolds (1980) and Reynolds (1980) are as follows:

1. Uraniun related to plutonic processes tends to be associated with potassium-rich rocks $\left(\mathrm{K}_{2} \mathrm{O}>4 \%\right.$ )

2. Uranium related to netamorphic processes may be transported by fluids released through dehydration reactions. Geochemical studies by Keith and Reynolds (1980) show that mylonitization is not associated with any changes in $U$ or Th concentration. However, the rich uranium deposit of Graeber Lease in the Kettle Metamorphic Core Complex, Washington, occurs in mylonitic gneisses and may be of metamorphic origin (Reynolds, 1980).

3. The dislocation surface and the underlying chloritic breccia represent a permeable horizon along which fluids migrated (Reynolds, 1980). Geochernical studies in the Rawhide Mountains by Keith and Reynolds (1980) show that these rocks are enriched 
in $U, T h, C u, Z n, F e, V, L i$ and $C r$ compared to the protolith, contain uranium occurrences, and more widespread hematite, limonite, Cu, and Au mineralization. Coney and Reynolds (1980) consider that investigation of these zones downdip into the nearby basins may be worthwhile.

Overall, metamorphic core complexes are moderately favorable for cu, Au and Ag deposits. Deposits in the Buckskin Mountains in the Bill Willams GRA of western Arizona formed along fracture zones related to dislocation surfaces and listric normal faulting . Circulation of metal-bearing fluids may have resulted from temperature gradients associated with the emplacement of the metamorphic core complexes and/or with mid-Tertiary volcanism.

In the Wymola GRA, numerous copper occurrences, and possibly the lead, copper, silver and gold deposits and occurrences in upper plate rocks of Picacho Peak (Ag $83 \& 84, \mathrm{~Pb} 154$ ), are associated with the Picacho Mountains metamorphic core complex. Much of the copper in the Picacho Mountains is merely chrysocolla staining (Johnson, 1981). Greater mineralization may exist in upper plate rocks which are buried by late Tertiary and Quaternary sediments on the southern, eastern and western sides of the Picacho liountains. One occurrence (85) and possibly another (3) appear to be associated with the metamorphic core complex at Desert Hills in the eastern part of the GRA.

Mid-Tertiary Volcanic Rocks

Mid-Tertiary volcanics in southern Arizona, southwestern New Mexico and Mexico are associated with gold-silver and base metal lode deposits (Damon et a1., 1981; Clark et a1., 1982). The volcanics were erupted when the magmatic are swept rather rapidly westward, possibly as a result of the steepening of the Benioff zone (Coney and Reynolds, 1977). In southwestern 
New Mexico the deposits are associated with cauldrons froin which voluminous ignimbrites and other volcanics were erupted (Elston, 1978). As yet, no such cauldrons have been identified in Arizona, but the voluminous ignimbrites and presence of numerous deposits suggest that such cauldrons could be present.

In the Wymola GRA, mid-Tertiary volcanics crop out in much of the southern two-thirds of the GRA and underly the deep basins (Eberly and Stanley, 1978). Two deposits (Mn 14, and Au 15, a past producer, are definitely related to a Tertiary hydrothermal event, and at least one ( $\mathrm{Cu} 2$, the North Star Mine) and possibly many more occurrences in the northern Picacho Mountains are related to a Tertiary intrusive. Sone roineralization in the Silver Bell and West Silver Bell Mountains, Waterman Mountains and Picacho Peak may also be a result of Tertiary magratism.

As mentioned previously in this report, an association between high potassium content in igneous rocks and high uranium content has been established (Keith and Reynolds, 1980; Reynolds, 1980). Ultrapotassic trachytes and trachyandesites (unit Tvi, fig. 3) of Picacho Peak and the south-central part of the GRA, with up to $14 \% \mathrm{~K}_{2} \mathrm{O}$ (Shafiqullah et al., 1976), must be considered as excellent source rocks for uranium deposits. Some sediments are interbedded with the volcanics; if they contain adequate reductants uranium could concentrate. Although no uranium occurrences have been reported, the potassium-rich mid-Tertiary volcanics and sediments have at least low favorability for uraniun occurrences.

\section{Mid-Tertiary Sediments}

Mid-Tertiary valley-fill sediments are widespread in central and southern Arizona, and since the discovery of the Anderson Mine (Sherborne et al., 1979), have become a prine target for uranium exploration. In order for a uranium defosit to form by the agency of groundwater or connate water, 
it is necessary to have an adequate uranium source rock, permeable sediments for water to flow through, and a reductant to precipitate the uranium. In the southern part of the GRA where the mid-Tertiary sediments are located, suitable source rocks may be the mid-Tertiary volcanics, especially the ultrapotassic volcanics, and possibly the Precambrian granites. The mid-Tertiary sediments are interbedded in the volcanics and are suitably permeable. It is not known where the reductants are present, but past or present geothermal waters (Gt 157 and Gt 158) could be sufficiently reducing to cause uranium precipitation. No uranium occurrences are located in mid-Tertiary sediments of the Wymola GRA, but Tertiary sediments in the deep basins of the GRA, especially those near the metamorphic core complexes and ultrapotassic Tertiary volcanics, should be considered as possible sites of uranium concentration.

Richard and Courtright (1966) report the occurrence of a mid-Tertiary conglomerate or fanglomerate which consists mainly of clasts of the leached cap of one of the Silver Bell Mine ore bodies. To the north of the GRA, in the White Canyon area, Kennecott is exploring the mid-Tertiary Whitetail Conglomerate, which is comprised of clasts of mineralized Pinal Schist that were deposited as talus. It is possible that a similar conglomerate, composed of mineralized clasts and not leached cap, could be found in the southern part of the Wymola GRA.

Late Tertiary Sediments

Late Tertiary sediments are present in all basins formed as a result of Basin and Range faulting, including the basins of the GRA (see fig. 1; Eberly and Stanley, 1978). As in the case of the mid-Tertiary sediments, adequate uranium source rocks and permeable horizons are present. Extensive organic reductants are not known to be present in these sediments but warm geothermal 
waters (Gt 157, 158) could be sufficiently reducing to cause uraniutu precipitation. No uraniug occurrences are known to be present within the late Tertiary sediments of the GRA.

Thick anhydrite beds, with lesser halite, were discovered by drilling done in the Picacho Basin of the western part of the GRA (Peirce, 1981 and 1976, Eberly and Stanley, 1978). This deposit is not being exploited but does represent a potential resource.

Analcite (Ze 156), a zeolite mineral, occurs in subsurface tuffaceous lacustrine sediments of the Picacho Basin (Arizona Bureau of Mines, 1969) and was also discovered by oil and gas drilling. The potential for large zeolite deposits, like those currently being exploited in southeastern Arizona, must be considered as low to moderate in deep basins of the GRA.

Recent Alluviun

Alluvium deposited in present-day stream valleys is a possible site for concentration of placer gold. Johnson (1972) reports that stream beds in the Silver Bell Mountains or surrounding area were worked for gold, but the location of the deposit is unknown and there are no records of production.

Geothermal

Extensive but low temperature geothermal resources are known to be present in southern Arizona (Jones, 1979). Factors that are favorable for the existence of substantial geothermal systems are: Presence of a high temperature heat source; presence of aquifers which allow large volumes of water to circulate through the hot rocks; and the presence of cap rocks which prevent the escape to the surface of at lease sone of the hot fluid.

In southern Arizona the intensity of volcanic activity has been waning during the past $9 \mathrm{~m} \cdot \mathrm{y}$. and that may explain why most geothermal areas are 
at a low temperature. Aquifers and cap rocks are plentiful and extensive in Tertiary valley-fill sediments. Both the Picacho Basin and the Avra Valley (Gt 158) in the Wymola GRA are considered by Witcher and others (1982) as areas of low temperature geothermal waters. Temperatures and depths of wells range from $32^{\circ} \mathrm{C}(235 \mathrm{~m})$ to $110^{\circ} \mathrm{C}(3101 \mathrm{~m}$ - Exxon State (74) No. 1 oil and gas exploration well, listed as 159 on fig. 3 and in the deposit listings).

\section{Mineral Economics}

The assessment of the geological, energy and mineral resources favorability should rely upon not only geology, but must also be concerned with economic factors and priorities. Discovery, recovery, cost of production of the resource from sources with varyng qualities and/or concentrations are included in those considerations. Special consideration must be given to the strategic and critical minerals and metals. As this project is of limited scope, and because of special difficulties in southwestern Arizona, economic analyses of various comodities can only be discussed briefly.

Some factors especially important to the evaluation of the mineral and energy resources of southern Arizona include the following:

1. The geology of the Wymola GRA is very complex and detailed information on the geology and mineral deposits of the WSAs is, for the large part, limited. This is multiplied by recent and ongoing reinterpretations of the geology of the Basin and Range in Arizona. In order to interpret the geology of the WSAs, and thus be able to project the types of mineral deposits that may be present in those areas, it is necessary to apply information about known areas of apparently similar geology to the interpretation of the geology of the WSAs. These are not optimum 
conditions. A wide variety of possibilities must be considered and, therefore, discussions of mineral economics must be considered tentative.

2. Contributing to the problems listed above, and creating some other distinct difficulties, are the ruggedness and roadless nature of the WSAs. Roadlessness, a criterion for WSAs, inhibits exploration and development of wineral resources due to poor access, distance to market, and other factors which increase the expense and difficulty of geological and mineral exploration.

3. A number of commodities, including strategic and critical minerals and metals, are known to occur in the GRA.

4. Considering all the above mentioned problems, it is very possible that sophisticated methods currently used by professional geologic explorationists have not been fully employed in southern Arizona. Many of the mines and occurrences in the GRA were discovered many years ago by prospectors using simple techniques.

Three copper occurrences are located within the Picacho Mountains WSA (020-194). One past producer of copper, lead and zinc is located within the Ragged Top WSA (020-194) and several occurrences of copper, along with gold, manganese and barite are located within two miles of the WSA boundary. There has been much recent speculation about the potential for oil and gas occurrences in the Basin and Range of southern Arizona. It has been suggested that the Overthrust Belt, related to oil occurrences from Canada to Utah, extends into Arizona as a wide NW-SE trending belt curling around the Colorado Plateau in the Basin and Range area (Peirce, 1982; Anschutz, 1980). 
The theory states that around $60 \mathrm{~m} \cdot \mathrm{y} \cdot \mathrm{B} \cdot \mathrm{P}$. older crystalline rocks thrust over younger, possibly oil-rich, strata (Peirce, 1982). The complex structures, including Basin and Range faults, found in southern Arizona coupled with the high temperatures created by igneous activity since that time dim the possibility of preservation of oil and gas. Peirce (1982) states if the Overthrust Belt exists, or ever has existed, in Arizona, geologic complexity obscures it and drilling has not yet resolved the issue. Anschutz (1980) suggests that the Overthrust Belt could become the most important oil and gas province to be discovered in the last 20 to 30 years, but also states that it is one of the most difficult and expensive areas to explore and develop.

Strategic and Critical Minerals and Metals

Within the WSAS of the Wymola GRA are a few occurrences of the stragegic and critical minerals and metals copper, lead and zinc.

Zinc has a variety of industrial applications, the most important being zinc-base alloy die castings, galvanizing iron and steel products, and brass production. Much of the lead used in the United States is consumed in the manufacture of storage batteries and as a gasoline additive, although use in gasoline is not as important as it once was. Use in ammition and solder is also important, increasingly so during wartime. Copper, although considered a strategic and critical metal, occurs in abundance in Arizona.

In summary, it must be noted that the Wymola GRA contains a large number of mineral occurrences and many different commodities. Deposits of strategic and critical commodities, some which have produced, are known to occur in the WSAs and surrounding parts of the GRA. Further exploration could lead to the discovery of potentially important deposits in the GRA and WSAs. 
THE GEOLOGY, ENERGY AND MINERAL RESOURCES

OF THE WILDERNESS STUDY AREAS

In this section each individual WSA is discussed with respect to its physiography, geology, mineral occurrences, resource potential, and recommendations for further work. For most of the WSAs, detailed and specific information is lacking; in these cases, information pertinent to the particular WSA will be summarized from the preceding sections. The classification of resource potential and level of confiaence is according to the scheme provided by the Bureau of Land Management (attachment 9, dated March 24, 1982). The classification is summarized on the maps in Figures 8 through 10 and detailed below.

\section{Classification Scheme}

1. The geologic environment and the inferred geologic processes do not indicate favorability for accumulation of mineral resources.

2. The geologic environment and the inferred geologic processes indicate low favorability for accumulation of mineral resources.

3. The geologic environment, the inferred geologic processes, and the reported mineral occurrences indicate noderate favorability for accumulation of mineral resources.

4. The geologic environment, the inferred geologic processes, the reported mineral occurrences, and the known mines or deposits indicate high favorability for accumulation of mineral resources.

Level of Confidence Schere

A. The available data are either insufficient and/or cannot be considered as direct evidence to support or refute the possible existence of mineral resources within the respective area. 
B. The available data provide indirect evidence to support or refute the possible existence of mineral resources.

C. The available data provide direct evidence but are quantitatively minimal to support or refute the possible existence of mineral resources.

D. The available data provide abundant direct and indirect evidence to support or refute the possible existence of mineral resources.

The Picacho Mountains WSA (020-194)

Physiography

The WSA lies on the southern part of the Picacho Mountains. Slopes in the north- to northeast-trending Picacho Mountains are steep; total relief in the WSA is about 2700 feet.

\section{Geology}

The WSA is almost entirely underlain by locally mylonitic muscovitebiotite gneiss and associated schists, augen gneisses and dikes of a midTertiary metamorphic core complex. Parts of the western portion of the WSA are underlain by Quaternary sediments, most likely pediment and fan deposits.

Mineral Deposits

Three copper prospects and occurrences are located within the WSA and numerous other occurrences, prospects and mines (4, the Gold Bell Mine) occur within a couple of miles outside the WSA boundaries. Yeend (1976) gave only a brief description of the copper mineralization, stating that chrysocolla and/or hematite are found in quartz veins one inch to eight feet in width. 
Metamorphic core complexes have been recognized in Arizona only recently and little is certain about the relationship between core complexes and mineralization. Recent studies by Keith and Reynolds (1980) and Reynolds (1980), however, found that the dislocation surface and underlying chloritic breccia are enriched in U, Th, Cu, $\mathrm{Zn}, \mathrm{Fe}, \mathrm{V}, \mathrm{Li}$ and $\mathrm{Cr}$ compared to the protolith, contain uranium occurrences and more widespread hematite, limonite, Cu and Au mineralization.

Land Classification for GEM Resources Potential Metallic Minerals

The WSA (area l; fig. 8) is classified as having moderate favorability for the occurrence of metallic minerals at a confidence level of $B$. The reasons for the above classification are as follows:

(a) Copper occurrences are known within the WSA, and

(b) Uranium occurrences and copper and gold mineralization, as well as high concentrations of $\mathrm{Fe}, \mathrm{Cr}$, and $\mathrm{Zn}_{\mathrm{n}}$ are reported for other metamorphic core complexes, however:

(c) Little is reported of the extent of mineralization within the Picacho Mountains, and dislocation surfaces, which have been eroded away in all but one small area in the very southeastern most Picacho Mountains, and chloritic breccias, which remain only in several small areas of the Picacho Mountains, are believed to be the parts of core complexes that are wost likely to be mineralized.

(d) The level of confidence is not high because the relationship between metamorphic core complexes and mineralization is still in the early stages of understanding. 


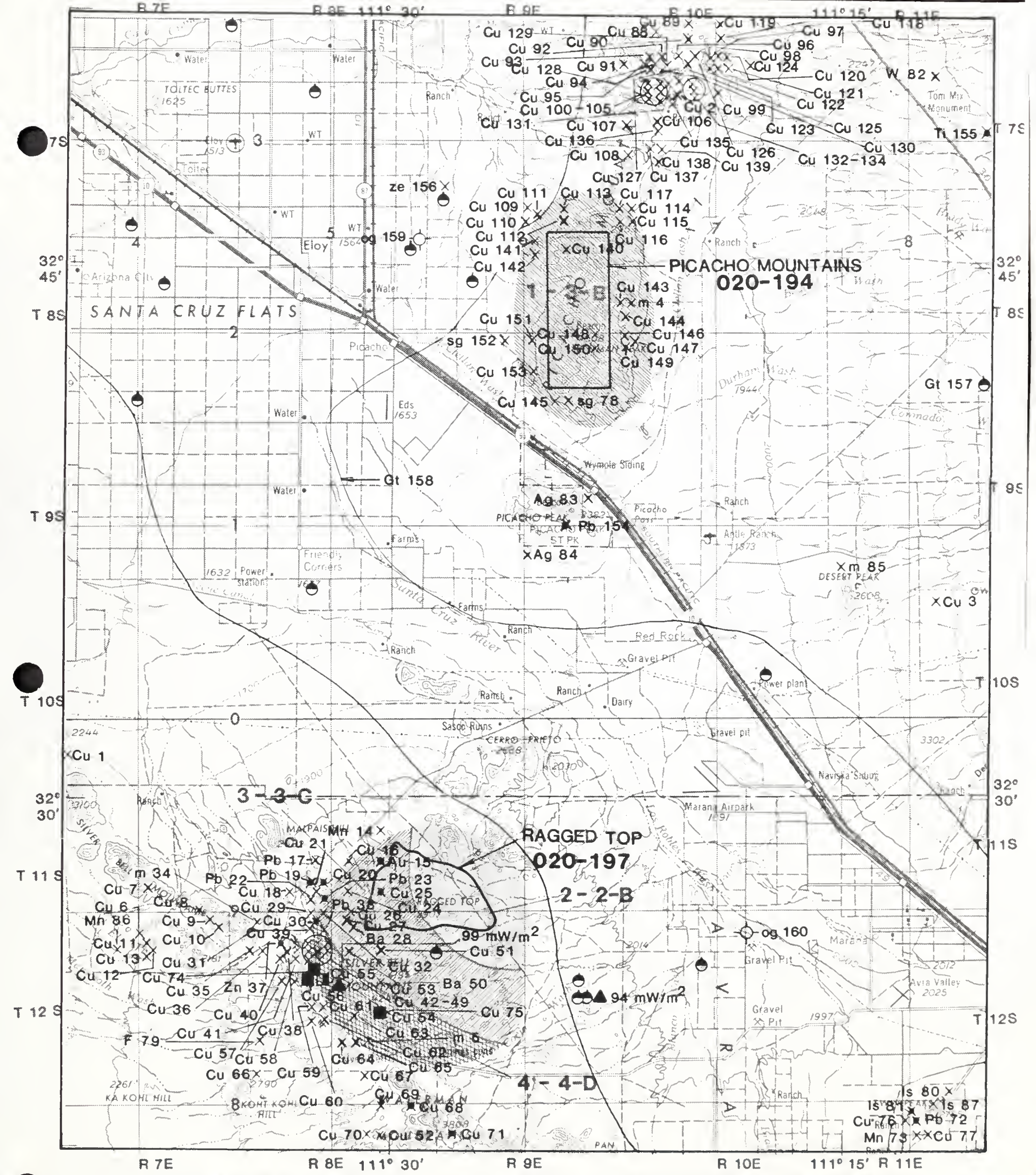

FIG.8 FAVORABILITY AND LEVEL OF CONFIDENCE MAP FOR METALLIC MINERAL
RESOURCES OF THE WYMOLA AREA, ARIZONA 
Uranium

The WSA (area 5, fig. 9) is classified as having low favorability for the occurrence of uranium at a confidence level of $B$. The reasons for this classification are as follows:

(a) No uranium occurrences have been found in the WSA, however,

(b) Uranium occurrences and anomalously high concentrations of uranium, thorium and other elements are reported for metamorphic core complexes of the Rawhide Mountains and the rich Graeber lease uranium deposit of Rettle Dome, Washington, may have formed by processes related to formation of the metamorphic core complex.

Other Resources

The WSA is not favorable for the occurrence of other resources at a confidence level of $B$ as there are no indications suggesting their presence.

The Ragged Top WSA (020-197)

\section{Physiography}

The WSA lies within an area of low hills overlooking Santa Cruz Plats (the Picacho Basin) and the Avra Valley that is dominated by Ragged Top, a steep-sided butte. Ragged Top is an outcropping of Tertiary intrusive rock and may be a volcanic neck or subvolcanic pluton. Total relief of the WSA is about 1700 feet.

\section{$\underline{\text { Geology }}$}

In the Ragged Top WSA, older Precambrian granitics are overlain by younger Precambrian Apache Group sediments and intruded by Precambrian diabases. Cretaceous andesites in the southwestern part of the WSA have 

been intruded by Laramice igneous rocks, probably dacite porphyry. MidTertiary sediments overlie the Precambrian granitic rocks and Apache Group sediments in the eastern part of the WSA. Mid-Tertiary volcanics of andesitic to trachytic composition crop out at the southeastern and northwestern corners of the area and a Tertiary intrusive, possibly a plug or sub volcanic stock, crops out at Ragged Top. Quaternary sediments overlie the rocks in the northwest and southeast. A northeast-trending fault in the center of the WSA cuts all the Precambrian units, Cretaceous andesite and the Tertiary intrusive.

\section{Mineral Deposits}

One deposit with past production, the Franco Riqueza Claims ( Cu 25), is located within the WSA. Copper, lead and zinc have been recovered. Several other occurrences and deposits are located within a mile of the western and southwestern boundaries of the GRA, including an unnamed hydrothermal gold prospect (Au 15), located in Cretaceous or Tertiary red beds, which has produced a small amount of ore.

Geologic environments similar to those in the WSA occur elsewhere in the GRA and contain mineral deposits of the following types:

(a) Hydrothermal veins, most containing copper but also some with lead, zinc, gold, silver, barite, fluorite and manganese, occur in Precambrian granitics and diabases, Cretaceous andesites, Cretaceous and/or Tertiary sediments and nid-Tertiary volcanics. These deposits are located west and southwest of the WSA in the Silver Bell and West Silver Bell Mountains.

(b) Tertiary sediments found a few miles to the south of the WSA in the Silver Bell Mountains contain abundant clasts of leached cap material from Silver Bell porphyry copper 
deposits. Rocks with higher-grade mineralization may have been eroded, also.

Land Classification for GEM Resources Potential

Metallic Minerals

Area 2 (fig. 8), including the eastern two-thirds of the WSA, is classified as having low favorability at a confidence level of B. The reasons for this are as follows:

(a) No occurrences have been found in the area, but

(b) Similar geologic environments that contain mineralization exist elsewhere in the GRA, and undiscovered occurrences and deposits may be associated with the Tertiary intrusive at Ragged Top.

(c) It is possible that Laramide intrusives, associated with porphyry copper deposits, occur beneath the WSA.

West and southwest of area 2 and continuing to the northwesternmost of the three major structures in the Silver Bell Mountains (area 3 ), is classified as moderately favorable for the occurrence of metallic minerals at a confidence level of $\mathrm{C}$. The reasons are as follows:

(a) Several deposits, including some past producers, occur in this area .

(b) Nearby to the south are the porphyry copper deposits of the Silver Bell Mine. Laramide intrusive rocks were responsible for the mineralization and similar Laramide porphyry rocks may occur within the Laramide intrusive bodies in area 3.

The area south of area 3 (area 4) includes the rich deposits of the Silver Bell Mines. Many millions of tons of ore containing copper with lesser molybdenum, gold, lead, zinc, silver and occurrences of barite, 
fluorite, bismuth and cadmium, have been produced from rich replacement deposits on Paleozoic limestones and quartzites and from disseminated deposits in Laramide porphyry intrusives. This area (area 4) is classified as highly favorable for the occurrence of metallic minerals at a confidence level of D.

Uranium

Areas in the WSA underlain by Precambrian diabases and Apache Group sediments, highly potassic mid-Tertiary volcanics, mid-Tertiary intrusives and mid-Tertiary sediments (area 6) is classified as having low favorability for the occurrence of uranium at a confidence level of $B$. The reasons for this classification are as follows:

(a) No uranium occurrences have been located in the WSA or CRA, however

(b) Organic-rich siltstones of the Apache Group contain uranium deposits near diabase intrusions in localities in Gila County to the northeast of the Wymola GRA. In addition, highly potassic volcanic rocks most frequently contain anomalously high amounts of uranium. Sediments interbedded with the mid-Tertiary potassic volcanics, Tertiary sediments and the Tertiary intrusive which may be related to the potassic volcanics all could contain uranium.

Non-metallic Minerals

The portion of the WSA underlain by Precambrian granitic rocks (area 7) is classified as having low favorability at a confidence level of A. The reasons are as follows: 
(a) Precanbrian granitic rocks in Arizona often contain pegmatites which may include resources of mica, feldspar and other non-metallics. However,

(b) No occurrences are reported in this area and it is unknown if pegmatites are existent in this Precambrian granitic body.

\section{Other Resources}

The WSA is considered unfavorable for the occurrence of other resources. No occurrences of other resources are known and deposits aside from those types discussed in the previous paragrpahs are highly unlikely to be found in the Rageed Top WSA.

Recommendations

For area 1 it is recommended that:

a The area should be field checked for the presence of hydrothermal alteration.

b. The three copper occurrences should be field checked to determine the extent of mineralization.

c. Schist bodies, possibly containing chloritic breccia, should be field checked and given special attention in checks for alteration and mineralization. Additionally, they should be checked to see if dislocation surfaces and upper plate rocks are present atop the schist bodies. When Yeend (1976) mapped the area, metamorphic core complexes were not well recognized in Arizona.

For area 2 it is recommended that:

a The area should be field checked for hydrothermal alteration.

b. Tertiary sediments should be investigated to check for the presence of conglomerates rich in mineralized clasts. 
For Area 3 it is recommended that:

a. Deposits Au 15 and $\mathrm{Cu} 25$ be field checked to evaluate the extent of mineralization.

b. Alteration minerals should be dated to determine the age of mineralization.

For area 5 and 6 it is recomended that:

a. Units Tvi and $T i$ in area 6 and schist bodies in area 5 (see Yeend, 1976) should be sampled and geochemical analysis for U, Th, K, Ca, phosphate, fluoride and carbonate should be performed.

In addition, it is recommended that outcroppings of Tertiary and Precambrian sediments be checked for the occurrence of organic-rich beds.

For area 7 , it is recommended that Precambrian granitics be field checked for the occurrence of pegmatites and especially mica and feldspar. 


\section{REFERENCES}

Anderson, C.A. and Silver, L.T., 1976, Yavapai Series - a greenstone belt, in Wilt, J.C. and Jenney, J.P., eds. Tectonic Digest: Arizona Geological Society Digest, v. 10, p. 13-26.

Anderson, P., 1976, Proterozoic convergent plate tectonics [abs.]: 25th International Geologic Congress, v. 1, p. 73.

Anderson, P. and Guilbert, J.M., 1979, the Precambrian massive sulfide deposits of Arizona - A district metallogenic epoch and province, in Ridge, J.D., ed., Papers on mineral deposits of western North America: Nevada Bureau of Mines and Geology Report 33, p. 39-48.

Anschutz, P.F., 1980, The overthrust belt: will it double U.S. gas reserves?: World Oil, January 1980, p. 111-116.

Arizona Bureau of Mines, 1969, Mineral and water resources of Arizona: Arizona Bureau of Mines Bulletin 180, 638 p.

Arizona Geological Society, 1952, Guidebook for field trip excursions in southern Arizona: Tucson, Arizona Geological Society, 150 p.

Banks, N.G., 1980, Geology of a zone of metamorphic core complexes in southeastern Arizona, in Crittenden, M.D., Jr., Coney, P.J., and Davis, G.H., eds., Cordilleran metamorphic core complexes: Geological Society of America Memoir 153, p. 177-186.

Bryant, D.L., 1968, Diagnostic characteristics of the Paleozoic formations of southeastern Arizona, in Titley, S.R., ed., Southern Arizona Guidebook III: Arizona Geological Society, p. 33-47.

Bryant, D.L., 1952, Paleozoic and Cretaceous stratigraphy of the Tucson Mountains, in Arizona Geological Society, Guidebook for field excursions in southern Arizona: Tucson, Arizona Geological Society, p. 33-42.

Burchfiel, B.C., 1979, Geologic history of the central western United States, in Ridge, J.I., ed., Papers on mineral deposits of western North Anerica: Nevada Bureau of Mines and Geology Report 33, p. 1-12.

Clark, K.F., Foster, C.T., and Damon, P.E., 1982, Cenozoic mineral deposits and subduction related magmatic arcs in Mexico: Geological Society of American Bulletin, v. 93, p. 533-544.

Coney, P.J., 1980, Cordilleran metamorphic core complexes - An overview: Geological Society of America Memoir 153, p. 7-31.

Coney, P.J. and Reynolds, S.J., 1980, Cordilleran metamorphic core complexes and their uranium favorability: U.S. Department of Energy Open File Report GJBX-258 (80).

Coney, P.J. and Reynolds, S.J., 1977, Cordilleran Benioff zones: Nature, v. $270, p \cdot 403-406$. 
Cooper, J.R., 1971, Mesozoic stratigraphy of the Sierrita Mountains, Pima County, Arizona: U.S. Geological Survey Professional Paper 658-D, 42 p.

Courtright, J.H., 1958, Progress report on investigations of some CretaceousTertiary formations in southeastern Arizona, in Anthony, J.W., ed., Arizona Geological Society Digest: Tucson, Arizona Geological Society, v. $1, \mathrm{p} .7-10$.

Damon, P.E., 1968, Application of the potassium-argon method to the dating of igneous and metamorphic rocks within the basin ranges of the southwest, in Titley, S.R., ed., Southern Arizona Guidebook III: Arizona Geological Society, p. 7-20.

Damon, P.E., and Mauger, R.L., 1966, Epeirogeny - orogeny viewed from the Basin and Range Province: Transactions of the American Institute of Mining, Metallurgical and Petroleum Engineers, v. 235, p. 99-112.

Damon, P.E., Shafiqullah, M., and Clark, K.F., 1981 Age trends of igneous activity in relation to metallogenesis in the southern Cordillera, in Dickinson, W.R. and Payne, W.D., eds., Relations of tectonics to ore deposits in the southern Cordillera: Arizona Geological Society Digest, v. $14, \mathrm{p} \cdot 137-154$.

Davis, G.H., 1981, Regional strain analysis of the superposed deformations in southwestern Arizona and the eastern Great Basin, in Dickinson, W.R. and Payne, W.D., eds., Relations of tectonics to ore deposits in the southern Cordillera: Arizona Geological Society Digest, v. 14, p. 155-172.

Davis, G.H., Anderson, J.L. Frost, E.G., and Shackelford, T.J., 1980, Mylonitization and detachment faulting in the Whipple-Buckskin-Rawhide Mountains terrain, southeastern California and western Arizona, in Crittendon, M.D. Jr., Coney, P.J., and Davis, G.H., Cordilleran metamorphic core complexes: Geological Society of America Memoir 153, p. 79-129.

Davis, G.H. and Coney, P.J., 1979, Geologic development of Cordilleran metamorphic core complexes: Geology, v. 7, p. 120-124.

Dickinson, W.R., 1981, Plate tectonic evolution of the southern Cordillera, in Dickinson, W.R. and Payne, W.D., eds., Relations of tectonics to ore deposits in the southern Cordillera: Arizona Geological Society Digest, v. 14, p. 113-135.

Dohms, P.H., Dunn, P.G., Harding, L.E., Lundin, R.J., Lynch, D.J., Reynolds, S.J. and Teet, J.E., 1980, Geologic road logs, 1979 Arizona Geological Society Field Trip, in Jenney, J.P. and Stone, C., eds. Studies in western Arizona: Arizona Geological Society Digest v. 12, p. 291-322.

Donnelly, M.E. and Hahn, G.A., 1981, A review of the Precambrian volcanogenic massive sulfide deposits in central Arizona and the relationship to their depositional environment, in Dickinson, W.R. and Payne, W.D., eds., Relations of tectonics to ore deposits in the southern Cordillera: Arizona Geological Society Digest, v. 14, p. 11-22. 
Eberly, L.D. and Stanley, T.B. Jr., 1978, Cenozoic stratigraphy and geologic history of southwestern Arizona: Geological Society of American Bulletin, v. 89, p. 921-940.

Elston, W.E. 1978, Mid-Tertiary cauldrons and their relationship to mineral resources, southwestern New Mexico: A brief review: New Mexico Geological Society Special Publication 7, p. 107-113.

Elston, W.E. and Bornhorst, T.J., 1979, The Rio Grande rift in context of regional post-40 m.y. volcanic and tectonic events, in Riecker, R.E., ed., Rio Grande rift: Tectonics and magmatism: American Geophysical Union, p. 416-438.

Fenneman, H.M., 1931, Physiography of western United States: New York, McGraw-Hill, $534 \mathrm{p}$.

Granger, H.C. and Raup, R.B., 1969, Geology of uranium deposits in the Dripping Spring Quartzite, Gila County, Arizona: U.S. Geological Survey Professional Paper 595, $108 \mathrm{p}$.

Graybeal, F.T., 1982, Geology of the El Tiro area, Silver Bell Mining District, Pima County, Arizona, in Titley, S.R., ed., Advances in the geology of the porphyry copper deposits: Tucson, the University of Arizona Press, p. 487-505.

Heidrick, T.L. and Titley, S.R., 1982, Fracture and dike patterns in Laramide plutons and their structural and tectonic implications, in Titley, S.R., ed., Advances in geology of the porphyry copper deposits: Tucson, The University of Arizona Press, p. 73-91.

Heindl, L.A. and MCClymonds, N.E., 1964, Younger Precambrian formations and the Bolsa Quartzite of Cambrian age, Papago Indian Reservation, Arizona: U.S. Geological Survey Professional Paper 501-C, p. C43-C49.

Johnson, G.S., 1981, The geology and geochronology of the northern Picacho Mountains, Pinal County, Arizona: Tucson, The University of Arizona M.S. thesis (unpub.), 65 p.

Johnson, M.G., 1972, Placer gold deposits of Arizona: U.S. Geological Survey Bulletin 1355, $103 \mathrm{p}$.

Jones, N.0., 1979, Geothermal resources - what to look for in Arizona: Arizona Bureau of Geology and Mineral Technology Fieldnotes, v. 9, No. 3, p. $12-13$.

Keith, S.B., 1981, The great southwestern Arizona overthrust oil and gas play: Arizona Eureau of Geology and Mineral Technology Fieldnotes, v. Il, No. 1, p. 1 .

Keith, S.B., 1980, The great southwestern Arizona overthrust oil and gas play: Arizona Bureau of Geology and Mineral Technology Fieldnotes, v. 10, No. $1, \mathrm{p} .1-3,6-8$. 
Keith, S.B., and Reynolds, S.J., 1980, Geochemistry of Cordilleran metamorphic core complexes, in Coney, P.J. and Reynolds, S.J., Cordilleran metamorphic core complexes and their uranium favorability: U.S. Department of Energy Open File Report GJBX-258(80), p. 274-303.

Lowell, J.D., 1974, Regional characteristics of porphyry copper deposits of the southwest: Economic Geology, v. 69, p. 601-617.

McCrory, F.J. and O'Haire, R.T., 1965, Map of known non-metallic mineral occurrences of Arizona: Arizona Bureau of Mines, scale 1:1,000,000.

Neilsen, R.L., 1979, Regional tectonics and the emplacement of Laramide porphyry copper intrusions - Arizona - New Mexico, in Ridge, J.D., ed., Papers on mineral deposits of western North America: Nevada Bureau of Mines and Geology Report 33, p. 49-56.

Oppenheiner, J.M. and Sumner, J.S., 1981, Gravity nodeling of the basins in the Basin and Range Province, Arizona: Arizona Geological Society Digest, v. 13, p. 111-116.

Peirce, H.W., 1982, The search for petroleum in Arizona: Arizona Bureau of Geology and Mineral Technology Fieldnotes, v. 12, no. 2, p. 1-5.

Peirce, H.W., 1981, Major Arizona salt deposits: Arizona Bureau of Geology and Mineral Technology Fieldnotes, v. 11, no. 4, p. 1-5.

Peirce, H.W., 1976, Tectonic significance of basin and range thick evaporite deposits: Arizona Geological Society Digest, v. 10, p. 325-339.

Rehrig, W.A. and Heidrick, T.L., 1976, Regional tectonic stress during the Laramide and late Tertiary intrusive periods, Basin and Range Province, Arizona, in Wilt, J.C. and Jenney, J.P., eds., Tectonic Digest: Arizona GeologicaI Society Digest, v. 10, p. 205-228.

Rehrig, W.A. and Reynolds, S.J., 1980, Geologic and geochronologic reconnaissance of the northwest-trending zone of metanorphic core complexes in southern and western Arizona: Geological Society of America Memoir 153, p. 131-157.

Reynolds, S.J., 1980a, A conceptual basis for the occurrence of uranium in Cordileran metamorphic core complexes, in Coney, P.J. and Reynolds, S.J., Cordilleran metamorphic core complexes and their uranium favorability: U.S. Department of Energy Open File Report GJBX-258(80), p. $187-246$.

Reynolds, S.J., 1980b, Geologic framework of west-central Arizona, in Jenney, J.P. and Stone, C., eds., Studies in western Arizona: Arizona Geological Society Digest, v. 12, p. 1-16.

Richard, Kenyon, and Courtright, J.H., 1966, Structure and mineralization at Silver Bell, Arizona, in Titley, S.R. and Hicks, C.L., eds., Geology of the porphyry copper deposits, southwestern North America: Tucson, The University of Arizona Press, p. 157-163. 
Scarborough, R.B. and Wilt, J.C., 1979, A study of uranium favorability of Cenozoic sedimentary rocks, Basin and Range Province, Arizona, Part I, General geology and chronology of pre-Late Miocene Cenozoic sedimentary rocks: The University of Arizona and U.S. Geological Survey Open File Report 79-1429.

Schmitt, H.A., 1966, the porphyry copper deposits in their regional setting, in Titley, S.R. and Hicks, C.L., eds., Geology of the porphyry copper deposits, southwestern North America: Tucson, University of Arizona Press, p. 17-33.

Shafiqullah, M., Damon, P.E., Lynch, D.J., Reynolds, S.J., Rehrig, W.A., and Raymond, R.H., 1980, K-Ar geochronology and geologic history of southwestern Arizona and adjacent areas: Arizona Geological Society Digest, v. 12, p. 201-260.

Shafiqullah, Muhamed, Lynch, D.J., Damon, P.E., and Peirce, H.W., 1976, Geology, geochronology and geochemistry of the Picacho Peak area, Pinal County, Arizona: Arizona Geological Society Digest, v. 10, p. 305-324.

Sherborne, J.E., Buckovic, W.A., Dewitt, D.B., Hellinger, T.S., and Pavlak, S.J., 1979, Major uranium discovery in volcanoclastic sediments, Basin and Range Province, Yavapai County, Arizona: American Association of Petroleum Geologists Bulletin, v. 63, p. $621-646$.

Shride, A.F., 1967, Younger Precambrian geology in southern Arizona: U.S. Geological Survey Professional Paper 566, 89 p.

Silver, L.T., 1978, Precaubrian formation and Precambrian history in Cochise County, southeastern Arizona, in Callender, J.F., Wilt, J.C. and Clemons, P.E., eds., Land of Cochise: New Mexico Geological Society Guidebook, 29 th Field Conference, Socorro, p. 157-163.

Silver, L.T. and Anderson, T.H., 1974, Possible left-lateral early to middle Mesozoic disruption of the southwestern North American craton margin [abs.]: Geological Society of America Abstracts with Programs, v. 6, p. 955-956.

Silver, L.T., Bickford, M.E., and Van Schinns, W.R., 1977, the $1.4-1.5$ b.y. transcontinental anorogenic plutonic performation of North America [abs.]: Geological Society of America Abstracts with Programs, v. 9, p. $1176-1177$.

Stensrud, H.L. and More, S., 1980, Precambrian geology and massive sulfide enviroments of west-central Hualapai Mountains, Mojave County, Arizona A preliminary report: Arizona Geological Society Digest, v. 12, p. $155-165$.

Stipp, T.F., Haigler, L.B., Alto, B.R., and Sutherland, H.L., 1967, Reported occurrences of selected minerals in Arizona: U.S. Geological Survey Mineral Investigations Resources Map MR-46, scale 1:500,000, 2 sheets.

Teichert, C., 1965, Devonian rocks and paleogeography of central Arizona: U.S. Geological Survey Professional Paper 464, 181 p. 
Texas Instruments, Inc., 1978, Aerial radiometric reconnaissance survey of proportions of Arizona-New Mexico: U.S. Department of Energy (NURE) Open-File Report GJBX-23(79).

Texas Instruments, Inc., 1975, Airborne geophysical survey, southeast Arizona: U.S. Energy Research and Development Administration (NURE) Open-File Report GJO-1643.

Titley, S.R., 1982, Geologic setting of the porphyry copper deposits, in Titley, S.R., ed., Advances in geology of porphyry copper deposits: Tucson, University of Arizona Press, p. 37-58.

Titley, S.R., 1976, Evidence for a Mesozoic linear tectonic pattern in southeastern Arizona: Arizona Geological Society Digest, v. 10, p. 71-101.

Tucker, W.C. Jr., 1980, Tectonic geomorphology of the Luke Air Force range, Arizona: Arizona Geological Society Digest, v. 12, p. 63-88.

Union Carbide Corporation, 1982, Hydrogeochemical and stream sediment reconnaissance basic data for the Tucson quadrangle: U.S. Department of Energy (NURE) Open-File Report GJBX-64(82).

U.S. Geological Survey, 1982 (entries dated 1981, 1980, 1979, 1977, 1976, 1973 and 1972), Computerized Resources Information Bank (CRIB): Computer printout records of August 2, 1982.

U.S. Geological Survey, 1972 (some entries revised 1979), CRIB Mineral Resources File 12, (see individual mineral deposit descriptions for record and page numbers).

Wilson, E.D., Moore, R.T., and Cooper, J.R., 1969, Geologic map of Arizona: Arizona Bureau of Mines and the U.S. Geological Survey, scale 1:500,000.

Witcher, J.C., Stone, C., and Mahman, W.R., 1982, Geothermal Resources of Arizona map: Arizona Bureau of Mines and Mineral Technology, scale $1: 500,000$.

Yeend, Warren, 1976, Reconnaissance geologic map of the Picacho Mountains, Arizona: U.S. Geological Survey Miscellaneous Field Studies Map MF-778, scale $1: 62,500$. 
0

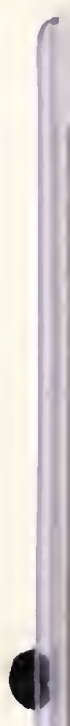

- 